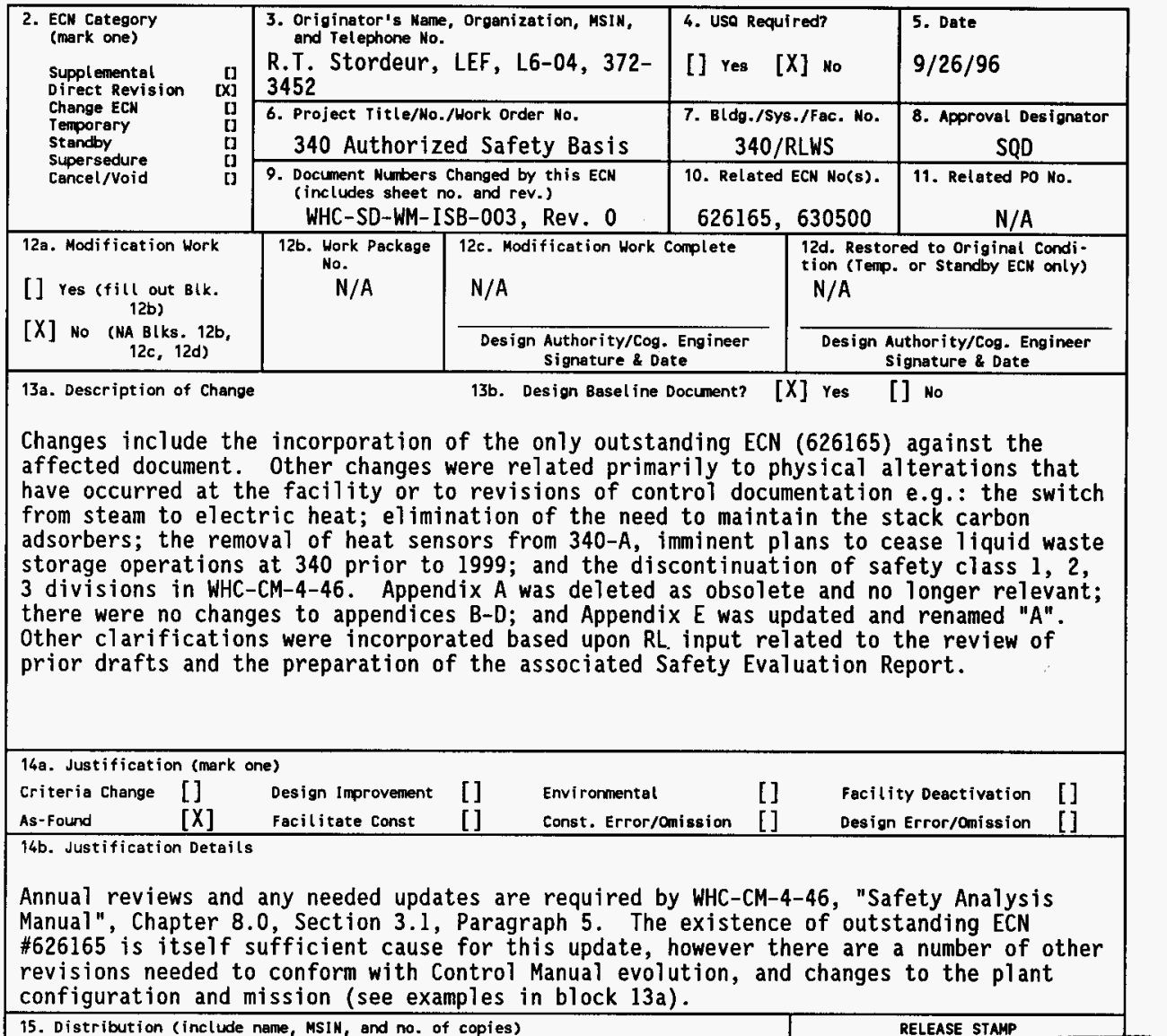

14a. Justification (mark one)
$\begin{array}{llllllll}\text { Criteria Change } & {[]} & \text { Design Improvement } & {[]} & \text { Environmental } & {[]} & \text { Facility Deactivation [] } \\ \text { As-Found } & {[X]} & \text { Facilitate Const } & {[]} & \text { Const. Error/Omission } & {[]} & \text { Design Error/Omission [] }\end{array}$

14b. Justification Details

Annual reviews and any needed updates are required by WHC-CM-4-46, "Safety Analysis Manual", Chapter 8.0, Section 3.1, Paragraph 5. The existence of outstanding ECN \#626165 is itself sufficient cause for this update, however there are a number of other revisions needed to conform with Control Manual evolution, and changes to the plant configuration and mission (see examples in block 13a). 15. Distribution (include name, MSIN, and no. of copies)
A.V. Beard
S7-55
L.W. Roberts*
L6-04
R.B. Bendixsen
T3-01
D.R. Schell*
H6-06
L.D. Bernesk $j *$
L6-04
R.T. Stordeur
L6-05
M.W Clayton*
L6-05
D.J. Williams*
S7-54
D.L. Halgren
L6-04
K.L. Leggett*
L6-40
Central Files (2) A3-88

* - W/o doc., as these people later get controlled copies

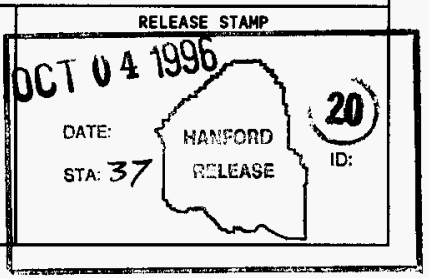




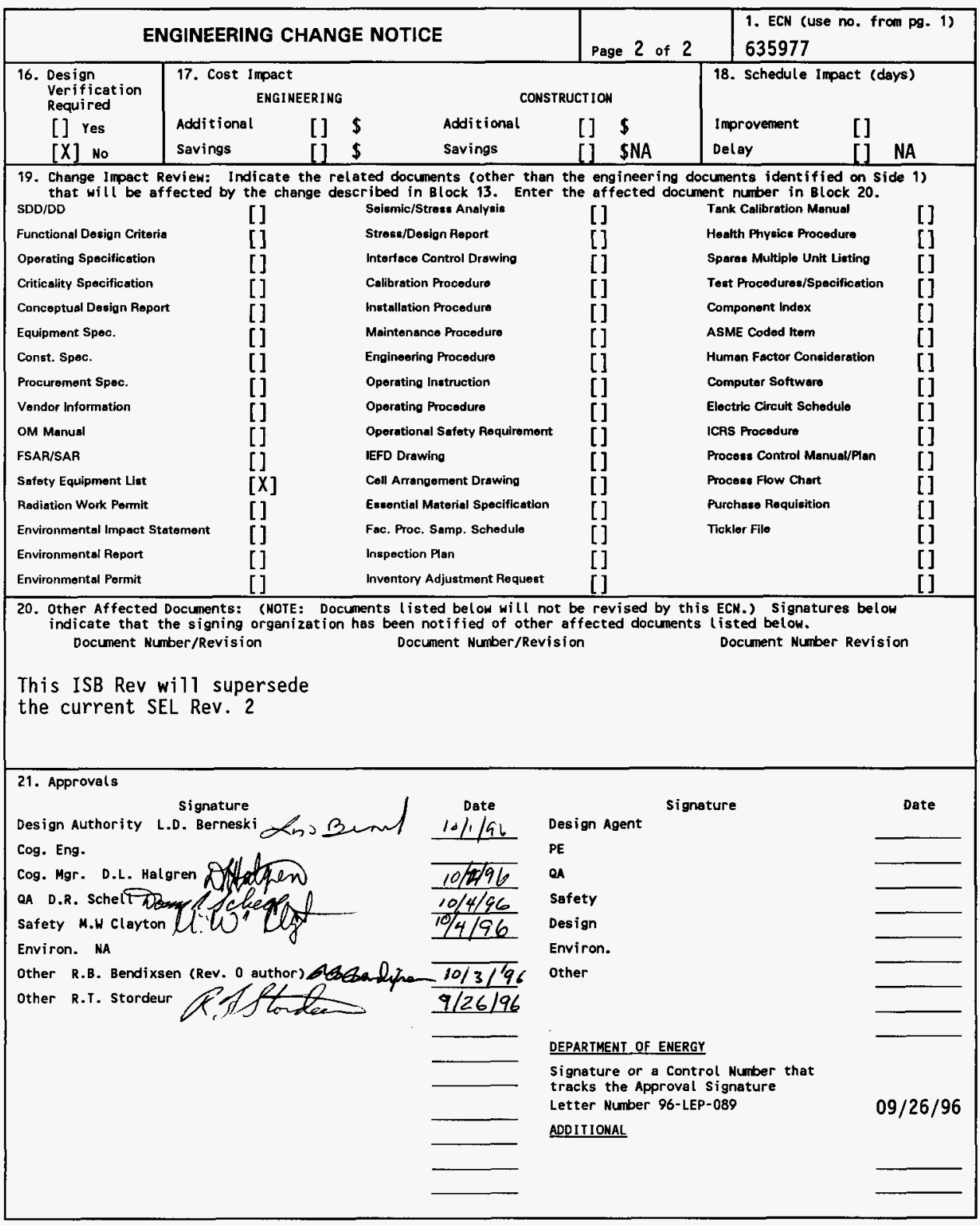




\title{
340 Waste Handling Facility Interim Safety Basis
}

\author{
R.T. Stordeur
}

Westinghouse Hanford Company, Richland, WA 99352

U.S. Department of Energy Contract DE-AC06-87RL10930

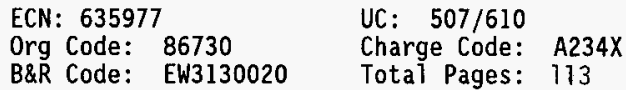

Key Words: 340 Facility, safety analysis, preliminary hazards analysis, interim safety basis, radioactive liquid waste system, storage tanks, 300 Area, operationai safety requirements, risk assessment, USQ process.

Abstract: This document presents an interim safety basis for the $\mathbf{3 4 0}$ Waste Handling Facility classifying the 340 Facility as a Hazard Category 3 facility. The hazard analysis quantifies the operating safety envelop for this facility and demonstrates that the facility can be operated without a significant threat to onsite or offsite people.

TRADEMARK DISCLAIMER. Reference herein to any specific comercial product, process, or service by trade name, trademark, manufacturer, or otherwise, does not necessarily constitute or imply its endorsement, recommendation, or favoring by the United States Government or any agency thereof or its contractors or subcontractors.

Printed in the United States of America. To obtain copies of this docunent, contact: WHC/BCS Document Control Services, P.0. Box 1970, Mailstop H6-08, Richland WA 99352, Phone (509) 372-2420; Fax (509) 376-4989.
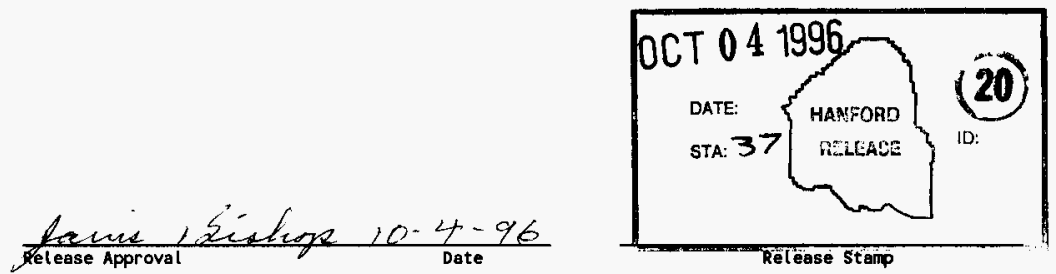

\section{Approved for Public Release}




\section{RECORD OF REVISION}

(2) Iitle

340 Waste Handling Facility Interim Safety Basis

CHANGE CONTROL RECORD

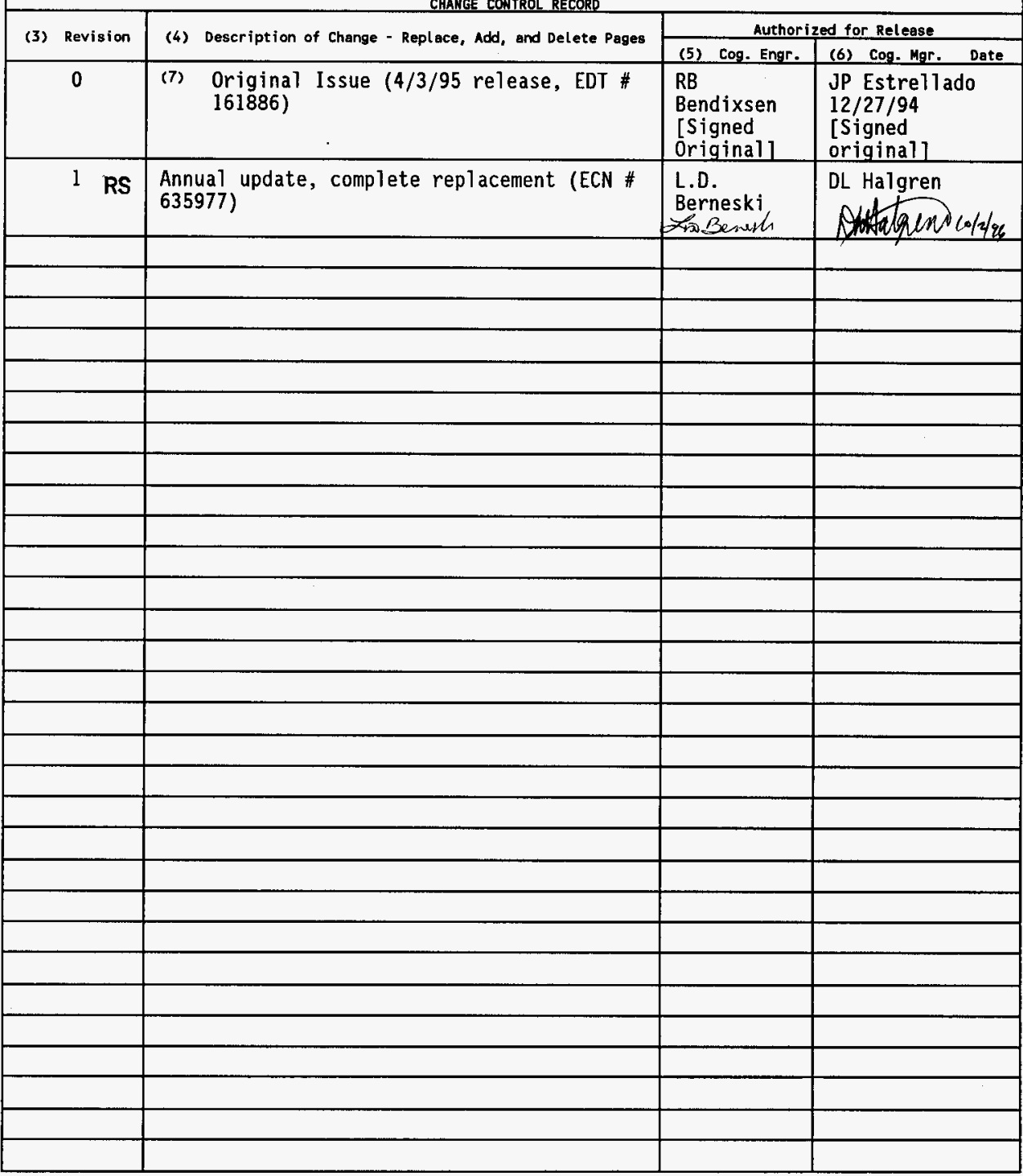




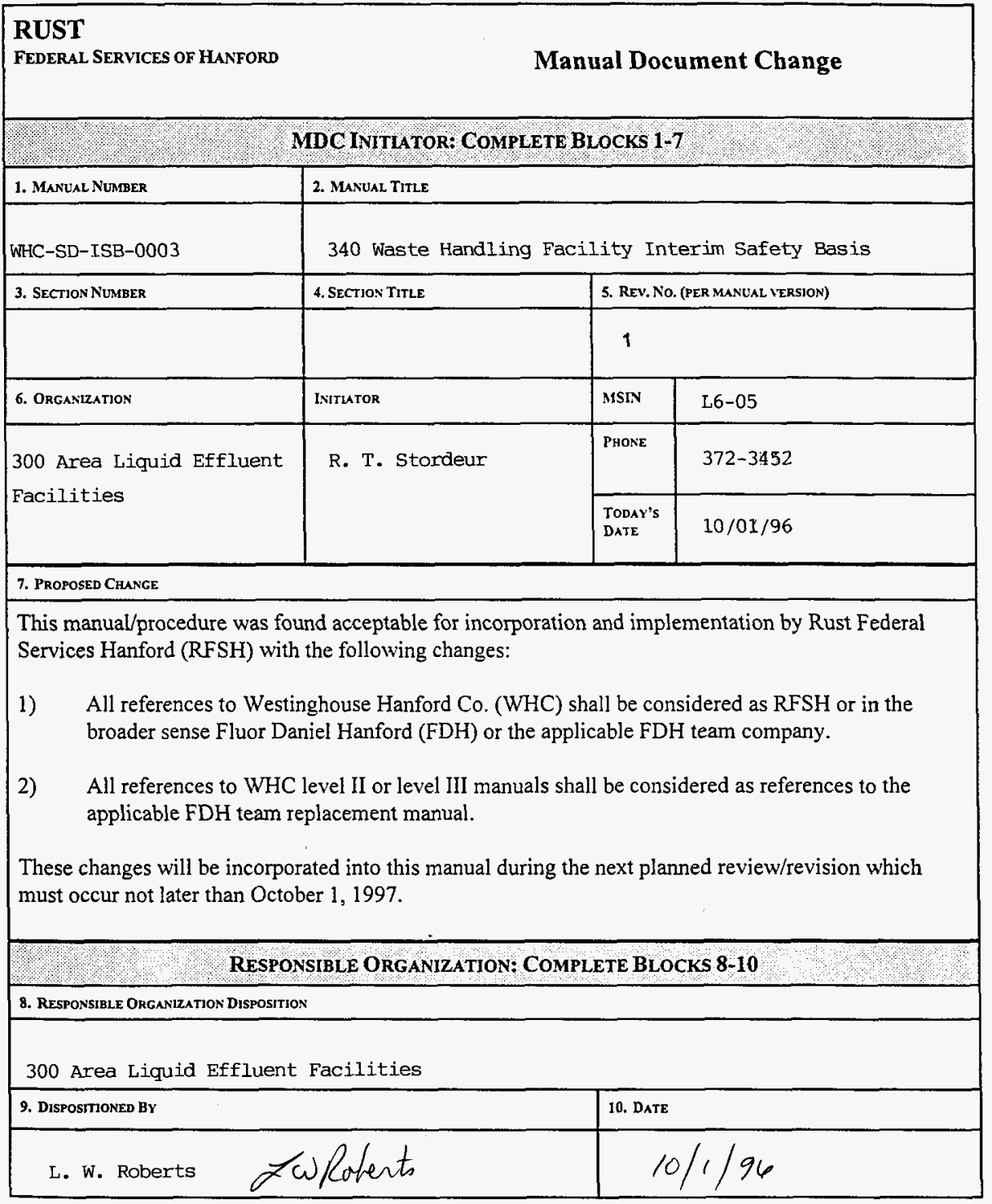


340 WASTE HANDLING FACILITY INTERIN

SAFETY BASIS

WHC-SD-WH-ISB-003

Rev. 1

September 1996 


\section{WHC-SD-WM-ISB-003, REV 1}

This page intentionally without substantive content. 


\section{CONTENTS}

LIST OF FIGURES ....................... iv

LIST OF TABLES ..................... iv

LIST OF TERMS

1.0 INTRODUCTION AND SUMMARY .................. 1-

1.1 PURPOSE . . . . . . . . . . . . . . . . 1-1

1.2 BACKGROUND $\ldots \ldots \ldots \ldots \ldots \ldots \ldots$

1.3 FACILITY STATUS . . . . . . . . . . . . . . . 1-2

1.4 FUTURE ACTIVITIES ................. . . . . . . .

1.5 CONFIGURATION MANAGEMENT $\ldots \ldots \ldots \ldots$

1.6 SUMMARY OF SAFETY ANALYSIS AND SUPPORTING INFORMATION $\ldots \ldots 1-3$

1.7 CONCLUSIONS . . . . . . . . . . . . . . 1-5

2.0 FACILITY DESCRIPTION . . . . . . . . . . . . . . 2-1

2.1 GENERAL ........................ 2-1

2.2 PROCESS/OPERATION . . . . . . . . . . . . . . 2-1

2.3 BUILDINGS . . . . . . . . . . . . . . 2-3

2.3 .1340 Building . . . . . . . . . . . . . 2-3

$2.3 .2340-$ A Building . . . . . . . . . . . . . . . 2-3

2.3 .3 340-B Building . . . . . . . . . . . . 2-4

2.3 .4 M0-036 Building ............... 2-4

2.3.5 MO-741 Building . . . . . . . . . . . . 2-4

2.4 RADIONUCLIDE AND HAZARDOUS MATERIAL INVENTORIES ..... $2-4$

2.4 .1340 Vault . . . . . . . . . . . . . 2-5

2.4 .2340 Building ................. 2- . 2-5

2.4 .3 340-A Building ............... 2-5

$2.4 .4340-$ B Building . . . . . . . . . . . . . . 2-5

3.0 INTERIM SAFETY BASIS EVALUATION .............. . . . . .

3.1 HAZARD ANALYSIS ................... . . . . . . .

3.1.1 Hazard Categorization ........... 3-1

3.1.2 Hazard Categorization Methodology . . . . . . . 3-2

3.1.3 Preliminary Hazards Analysis . . . . . . . . . . . 3-3

3.1.4 Accident Scenarios and Consequences ........ 3-5

3.1 .5 Risk Evaluation ............. 3-6

3.2 HAZARD CONTROLS ..................... 3-7

3.2.1 Structures, Systems and Components ........ 3-7

3.2.2 Administrative Controls/Operational Restrictions .... 3-9

3.2.3 Institutional Safety Programs . . . . . . . 3-13

3.3 SUMMARY . . . . . . . . . . . . . . . 3-17

4.0 CONFIGURATION CONTROLS SYSTEM ............... . 4-1

4.1 DRAWING CONTROL . . . . . . . . . . . . . . . 4-1

4.2 PROCEDURE CONTROL $\ldots \ldots \ldots$. . . . . . . .

4.3 UNREVIEWED SAFETY QUESTIONS . . . . . . . . . . . 4-2

4.4 QUALITY ASSURANCE ................... 4-2

5.0 REFERENCES .................... 5-1

5.1 DOCUMENTS . . . . 5-1

5.2 U.S. FEDERAL CODES AND DEPARTMENT OF ENERGY ORDERS/GUIDELINES . 5-2

5.3 WESTINGHOUSE HANFORD COMPANY CONTROLLED MANUALS . . . . . 5-3 


\section{APPENDICES}

A CONDUCT OF OPERATIONS COMPARATIVE EVALUATION ............ A-1

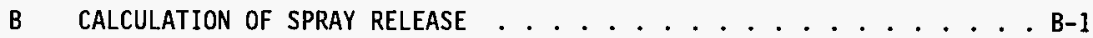

C GENII DOSE CONSEQUENCE CALCULATION FOR THE 340 FACILITY . . . . . c-1 D HAZARDOUS MATERIAL RELEASE ESTIMATES ............ D-1

\section{LIST OF FIGURES}

1-1. 340 Waste Handling Complex Site Plan . . . . . . . . . . 1-6

1-2. Aerial View of 340 Complex ................. 1-7

3-1. Onsite and Offsite Radiological Risk Comparison to Guidelines. . . 3-21

\section{LIST OF TABLES}

2-1. 340 Facility Radionuclide Inventory . . . . . . . . . . 2-7

2-2. 340 Facility Hazardous Material Inventory . . . . . . . . . 2-8

2-3. 340 Vault Tank Bounding Source Term . . . . . . . . . . 2-9

2-4. 340 Facility Solid Waste Bounding Source Term . . . . . . . . 2-9

3-1. 340 Vault Tank Hazard Category Calculations . . . . . . . . . . 3-20

3-2. Hazard Categorization of 340 B Building Solid Radioactive Waste . 3-20

3-3. Calculation of Plutonium Equivalent Curie/Liter . . . . . . . 3-20

3-4. 340 Waste Handling Facility Preliminary Hazard Analysis . . . . . . 3-21

3-5. Probability Category Definition and Qualitative Accident Severity Levels . . . . . . . . . . . . . . . . . . 3-27

3-6. Operating Hazards. . . . . . . . . . . . . . 3-28

3-7. Maximum Individual Dose Due to an Aerosol Release of 1 Curie of Each Isotope From the 340 Facility . . . . . . . . . . 3-30

3-8. Dose Consequences for a Spray-Release Accident . . . . . . . . 3-31

3-9. Dose Consequences When Burning the 340-B West Building Solid Wastes .................... . . . . . . . . . . . . . . .

3-10. 340 Facility Safety Enhancement Systems . . . . . . . . . 3-32 


\section{LIST OF TERMS}

$\begin{array}{ll}\text { ALARA } & \text { as low as reasonably achievable } \\ \text { ANSI } & \text { American National Standards Institute } \\ \text { CSER } & \text { criticality safety evaluation report } \\ \text { DOE } & \text { U.S. Department of Energy } \\ \text { EDE } & \text { effective dose equivalent } \\ \text { ERPG } & \text { Emergency Response Planning Guideline } \\ \text { FGE } & \text { fissile gram equivalent } \\ \text { FSAR } & \text { final safety analysis report } \\ \text { HSRCM } & \text { Hanford Site Radiological Control Manual } \\ \text { HEPA } & \text { high-efficiency particulate air (filter) } \\ \text { HPT } & \text { health physics technician } \\ \text { IOSR } & \text { interim operational safety requirements } \\ \text { ISB } & \text { interim safety basis } \\ \text { PHA } & \text { preliminary hazards analysis } \\ \text { Pacific } & \text { Pacific Northwest National Laboratory } \\ \text { Northwest } & \\ \text { QA } & \text { quality assurance } \\ \text { RL } & \text { Richland Operations office (DOE) } \\ \text { RLW } & \text { radioactive liquid waste } \\ \text { RLWS } & \text { radioactive liquid waste system } \\ \text { RPS } & \text { retention process sewer } \\ \text { RWP } & \text { radiation work permit } \\ \text { SSC } & \text { structures, systems, and components } \\ \text { TEDF } & \text { Treated Effluent Disposal Facility } \\ \text { TQ } & \text { threshold quantities } \\ \text { TQ } & \text { threshold quantities modified } \\ \text { TRU } & \text { transuranic } \\ \text { USQ } & \text { unreviewed safety question } \\ \text { WHC } & \text { Westinghouse Hanford Company } \\ & \end{array}$


WHC-SD-WM-ISB-003, REV 1

This page intentionally without substantive content. 


\subsection{INTRODUCTION AND SUMMARY}

\subsection{PURPOSE}

This document establishes the interim safety basis (ISB) for the 340 Waste Handling Facility (340 Facility). An ISB is a documented safety basis that provides a justification for the continued operation of the facility until an upgraded final safety analysis report (FSAR) is prepared that complies with U.S. Department of Energy (DOE) Order 5480.23, Nuclear Safety Analysis Reports. The ISB for the 340 Facility documents the current design and operation of the facility. Due to the limited remaining active life for the core of the 340 complex (see sections 1.3 and 1.4 ), this ISB (now Rev. 1) will continue to serve in place of an upgraded FSAR, per provisions in WHC-CM-4-46, Chapter 2.0.

The 340 Facility ISB (ISB-003) is based on a facility walkdown and review of the design and operation of the facility, as described in the existing safety documentation. The safety documents reviewed, to develop the initial Rev. 0 and this Rev 1 of ISB-003, included the following:

- OSD-SW-153-00001, Operating Specification Document for the 340 Waste Handling Facility (WHC 1990) [Canceled]

- 0SR-SW-152-00003, Operating Limits for the 340 Waste Handling Facility (WHC 1989) [Canceled]

- WHC-SD-RE-SAP-013, Safety Analysis Report for Packaging, Railroad Liquid Waste Tank Cars (Mercado 1993)

- WHC-SD-WM-TM-001, Safety Assessment Document for the 340 Waste Handling Facility (Berneski 1994) [Canceled]

- WHC-SD-WM-SEL-016, 340 Facility Safety Equipment List (Berneski 1992; and Rev 2, Vogel 1994) [Superseded]

- WHC-SD-WM-FHA-011, Rev. 0, 340 Complex Fire Hazard Analysis, (Roberts, 1995).

- WHC-SD-SQA-CSA-20379, Rev. 1, CSER 94-012: Criticality Safety Evaluation Report for 340 Building (Miller, 1996)

The safety assessment document for the 340 Facility, WHC-SD-WM-TM-001, has been determined to be outdated in its content. The facility description and hazard analysis applicable to the current facility status are addressed in ISB-003. WHC-SD-WM-ISB-003 supersedes WHC-SD-WM-TM-001 and the operational safety requirements document, OSR-SW-152-00003, for the 340 Facility.

The 340 Facility will comply with all applicable state and federal statutes, DOE Orders, rules, and regulations which establish safety constraints on the 340 Facility. The 340 Facility will comply with these regulations to ensure that all activities conducted at the facility proceed in a safe manner. Appendix A, Table A-1, contains a list of the applicable controls and safety requirements cross-referenced to the applicable DOE Orders, WHC Control Manuals, and 340 Facility Implementing Documentation. 


\subsection{BACKGROUND}

The 340 Facility (Figures $1-1$ and 1-2) is located in the 300 Area of the Hanford Site and provides the capability for receipt, temporary storage, and shipment of radioactive and mixed liquid wastes via the radioactive liquid waste system (RLWS). The RLWS is an underground piping system through which radioactive and mixed liquid wastes gravity drain from Pacific Northwest National Laboratory (Pacific Northwest) buildings into the 340 Building Vault Tanks. Pacific Northwest generates a majority of the radioactive and mixed liquid wastes in the 300 Area; however, infrequent transfers from Westinghouse Hanford Company (WHC) facilities also occur. As a result of operating and maintaining this system, some radioactive/mixed solid waste is generated during maintenance and repair of the facilities. The solid waste is packaged and temporarily stored before shipment to Solid Waste Disposal. The 340 Facility also accepts radioactive solid waste from other generators. The 340 Facility does not routinely handle solid transuranic (TRU) wastes and does not receive or store TRU waste from other generators.

The 340 Complex also manages the potentially radioactive, nonhazardous retention process sewer (RPS) Tiquid waste stream. The 307 Basins (Figure 1-1) serve as a holding/monitoring point for the RPS 1 iquid which discharges to the Treated Effluent Disposal Facility located north of the 300 Area. Use of the process trenches for disposal of waste water has been discontinued. Building diverters in Pacific Northwest laboratories monitor the RPS, and in the event that the RPS does become radioactively contaminated, the building diverters shift the building discharges to the RLWS. The RPS basins are periodically sampled before discharge and are, as appropriate, drained to the process sewer or pumped to the RLWS.

The 307 Basins were evaluated separately as part of the RPS (Berneski 1995) which determined that this system falls below the threshold for consideration under the requirements of DOE Order 5480.23 (1ess than a Hazard Category 3 facility as defined in DOE-STD-1027, Hazard Categorization and Accident Analysis Techniques for Compliance with DOE Order 5480.23, Nuclear Safety Analysis Reports). This evaluation for this nonnuclear process meets the requirements of DOE Order 5481.1B, Safety Analysis and Review System and has been issued as a supporting document (Berneski 1995).

\subsection{FACILITY STATUS}

The 340 Facility continues its mission to provide temporary storage for radioactive and mixed liquid waste and serve as a staging area for low-level radioactive and mixed solid waste. Planning is currently underway to deactivate those portions of the 340 Facility associated with radioactive and mixed liquid waste storage (WHC 1996b). The 340 Facility is not a routine generator of solid TRU waste and does not require a facility-specific TRU waste certification plan. The facility does generate low-level waste and has an approved waste profile (per WHC 1995b). The 340 Facility no longer provides decontamination services to other facilities. Flammable quantities of liquids are not allowed in the RLWS, which eliminates the potential for a fire in the 340-A Building and the Vault Tanks. Rags containing solvents, oil, combustibles or flammables are collected in a drum located outside of the 340 Building. 


\subsection{FUTURE ACTIVITIES}

Future projects that modify the 340 Facility will have a preliminary "safety analys is" completed before start-of-construction to document changes to the Facility Hazard Category and dose consequences from postulated accidents. This will ensure that the proposed modifications comply with current safety requirements and safety-related design criteria. Current plans call for the cessation of operations at 340 in the near future. Therefore, it is anticipated that no upgrade projects will be pursued, other than minor actions deemed necessary or prudent to place the facility systems and/or areas in a safe and stable condition such that cost effective surveillance and maintenance programs will prevent any unacceptable risk to the public or the environment until the facility can be ultimately dispositioned (WHC 1996b).

\subsection{CONFIGURATION MANAGEMENT}

The WHC configuration management program (WHC-CM-6-1, Standard Engineering Practices) addresses design changes and controls, with guidelines that cover changes to the facility documents (WHC-IP-1026, Engineering Practices Guidelines, WHC 1994a). The facility's cognizant engineers are responsible for identifying any additional documents, drawings, instructions, or procedures that are affected by a facility change. The documents requiring changes may include operating procedures, conduct of operations manual, and maintenance procedures. These changes require review and approval by Quality Assurance, Criticality safety, Environmental, and independent safety organizations as appropriate.

ISB-003 provides information relating to control of hazards at the 340 Facility (including design, engineering analysis, and administrative) from which the conclusion is made that current 340 Facility activities can be conducted safely. Changes to these descriptions will be updated at least annually via the engineering change procedure specified in WHC-CM-1-3, Management Requirements and Procedures. Also, WHC-CM-4-46, Nonreactor Facility Safety Analysis Manual, requires an annual update for safety analysis documentation.

\subsection{SUMMARY OF SAFETY ANALYSIS AND SUPPORTING INFORMATION}

The nature of the operations performed and the materials handled in this facility present potentials for nuclear accidents (e.g., exposure to direct radiation and radioactive contamination spread), as well as accidents of a more conventional nature (e.g., industrial accidents). Operation of the 340 Facility is managed as part of the WHC Liquid Effluent Services Department (300 Area Facility Function) within the Projects and Site Services Division.

The hazard analysis presented in ISB-003 establishes the 340 Facility Hazard Category as follows:

- RLWS Storage - Hazard Category 3, 340 Facility Vault Tanks and 340-A Building Tanks.

- Sol id Waste Storage - Hazard Category 3, 340 Facility

Decontamination Area and the 340-B Building. 
The maximum radionuclide inventory found in the dose-consequence calculations and the guidelines of DOE-STD-1027-92 were used to determine the hazard category.

The 340 Facility inventory consists primarily of liquid and solid waste containing mixed fission products and other radionuclides. To remain classified as an isolated facility, per WHC-CM-4-29, Nuclear Criticality Safety Manual, the 340 Facility must maintain < 177 fissile grams equivalent (FGE) of fissionable material. Administrative controls for inventory have been established through WHC-CM-4-29 and the 340 CSER (Miller, 1996).

The 340 Facility does not contain Safety Class or Safety Significant structures, systems, and components (SSC), per WHC-CM-4-46, Nonreactor Facility Safety Analysis Manual, Chapter 9.0.

The hazards associated with the 340 Facility have been analyzed in a preliminary hazards analys is (PHA) format in Section 3.0. Annual frequency and severity categories are presented with each hazard. The principle types of hazards considered are industrial, high radiation, radiological contamination, and natural disaster. The bounding hazards were further evaluated for consequence and risk acceptance.

The worst-case hazards that presented vulnerabilities in design or operation were identified as the spray leak in the 340-B East and the solid waste fire in the 340-B West Building. As a result of the changing concentration and distribution of isotopes in the 340 Facility RLWS, sufficient inventory could allow an unmitigated spray release to exceed onsite/offsite dose limits or Hazard Category 2 thresholds. The RLWS inventory was simplified into curies of beta/gamma and alpha emitters. A worst-case beta/gamma inventory of $100 \%{ }^{154} \mathrm{Eu}$ is assumed in a conservatjve approach because it has the highest onsite rem/Ci value. Similarly, ${ }^{239} \mathrm{Pu}$ has one of the highest onsite $\mathrm{rem} / \mathrm{C} i$ values and is assumed to be a worst-case alpha inventory. The tables in Section 3.0 assume a worst-case beta/gamma and alpha inventory of ${ }^{90} \mathrm{Sr}$ ( ${ }^{90} \mathrm{Sr}$ is more conservative for hazard category calculations than ${ }^{154} \mathrm{Eu}$ ) and ${ }^{239} \mathrm{Pu}$, respectively, for hazard category calculations. The calculated releases for the spray-leak, worst-case accident are within the risk-acceptance guidelines. The dose consequences are below the Safety Class and Safety Significant criteria. Operational restrictions of $66 \mathrm{Ci}$ total alpha and $39 \mathrm{kCi}$ total beta/gamma have been established for the vault tank to be pumped into the railroad tank car, based on the accident scenario and the inventory used in the dose calculations.

Similarly, an unmitigated solid waste fire in the 340-B West Building could exceed onsite/offsite dose limits or Hazard Category 2 thresholds with sufficient inventory. A total curie inventory of $10 \mathrm{C} \mathbf{i}$ beta/gamma and $1.5 \mathrm{C} i$ alpha were used in the dose calculations in Section 3.0. Once again, ${ }^{154} \mathrm{Eu}$ and ${ }^{239} \mathrm{Pu}$ were used as worst-case beta/gamma and alpha inventories for the dose calculations, and ${ }^{90} \mathrm{Sr}$ and ${ }^{230} \mathrm{Pu}$ were used as the worst-case inventories for the hazard category calculations. The calculated releases for this worst-case accident are within the risk-acceptance guidelines. The dose consequences are below the Safety Class and Safety Significant criteria. Operational restrictions of $1.5 \mathrm{Ci}$ total alpha and $10 \mathrm{C} i$ beta/gamma have been established for the solid waste based on the inventory used in the dose calculations. 


\subsection{CONCLUSIONS}

The analysis in this document establishes that the 340 Facility is adequately designed and controlled to operate without undue risk to the health and safety of the onsite worker, the public, and the environment. A PHA (Section 3.0) identifies bounding hazards for further evaluation. The accident dose consequences show that possible releases, as a result of a RLWS spray leak in the 340-B East Building and a solid waste fire in the 340-B West Building, are below risk-acceptance guidelines based on the maximum inventories established herein. Operational restrictions in Section 3.0 were established to ensure safe operation. These controls identify an operating envelope in which the 340 Facility's interim safety is based.

In accordance with DOE-STD-1027-92, the 340 Facility RLWS, and Solid Waste Storage have been determined to be Hazard Category 3 . Therefore, by providing a safety analysis based on the bounding source terms and the operations and design of the facility, it can be concluded that ISB-003 adequately defines the safe operating envelope. The safety analyses summarized in this document define the authorization basis for performing unreviewed safety question (USQ) screenings and evaluations in accordance with WHC procedures and DOE Order 5480.21, Unreviewed Safety Questions.

The conduct of operations for the 340 Facility, with respect to the institutional and safety controls, have been evaluated in this document. This evaluation compares facility-specific procedures to the WHC control manuals that implement the institutional and safety controls established by DOE Orders. Since ISB Rev. 0 was issued, the 340 procedures and administrative control documents have been upgraded to comply with the revisions (see Appendix A). Based on the results of the comparative evaluation, it can be concluded that the existing facility procedures adequately implement the WHC control manuals and have adequately addressed the 340 Facility conduct of operations. 
WHC-SD-WM-ISB-003, REV 1

Figure 1-1. 340 Waste Handling Complex Site Plan.

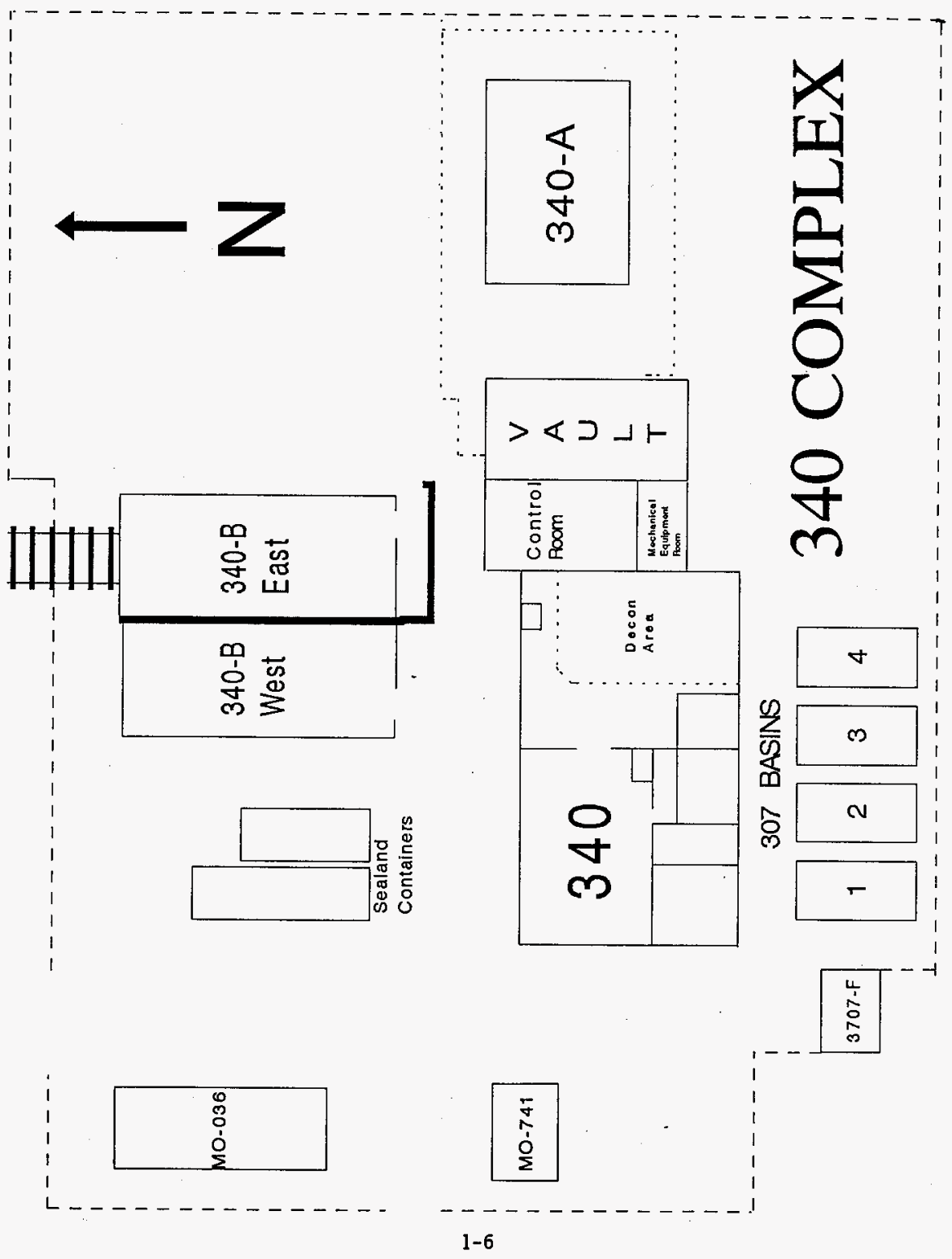


WHC-5D-WM-1SB-003, REV 1

Figure 1-2. Aerial View of 340 Complex

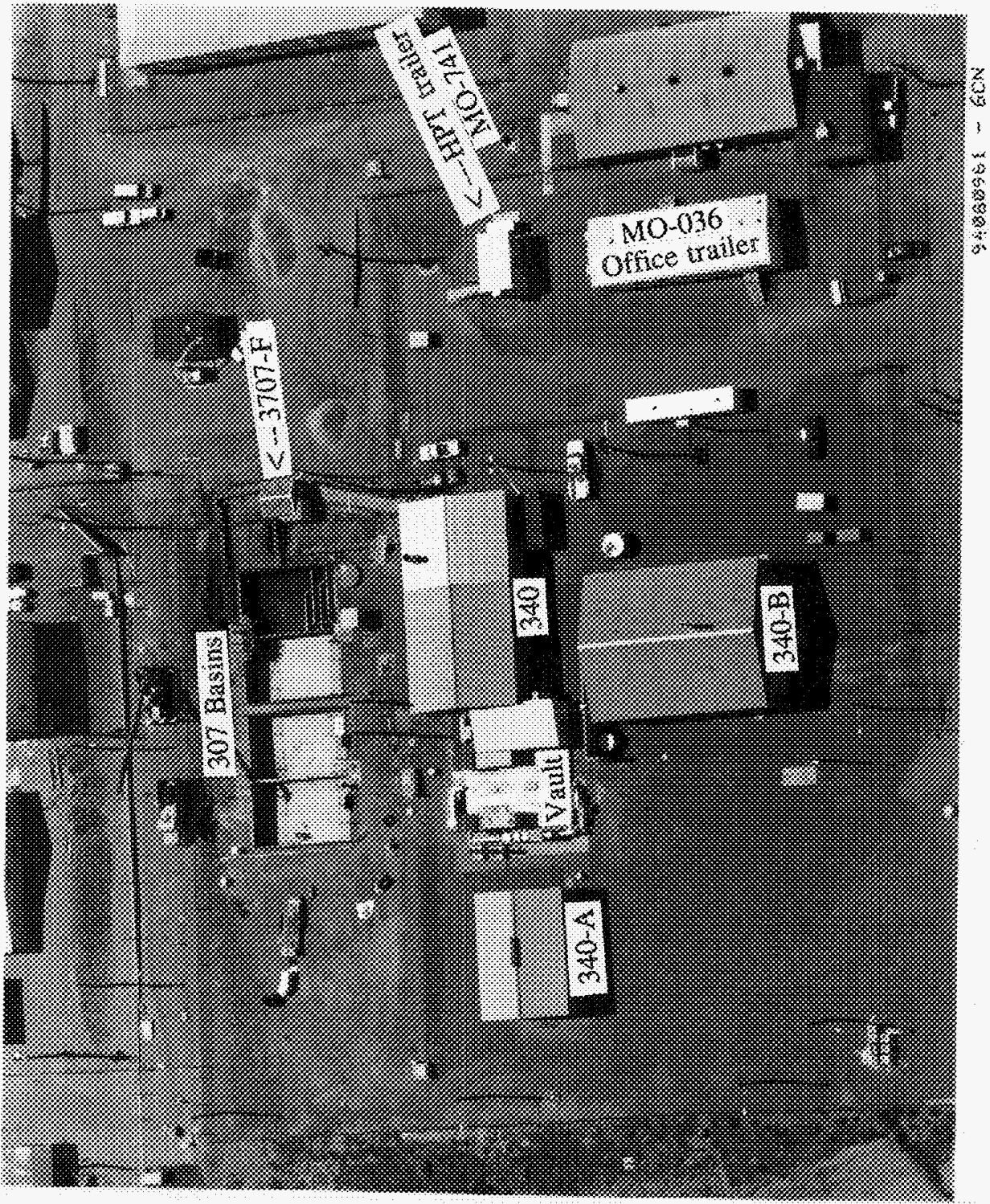


WHC-SD-WM-ISB-003, REV 1

This page intentionally without substantive content. 


\subsection{FACILITY DESCRIPTION}

\subsection{GENERAL}

The 340 Facility supports Pacific Northwest operations through the receipt, storage, and shipment of radioactive liquid wastes generated during laboratory operations. The 340 Facility also occasionally receives liquid waste from WHC facilities in the 300 Area. Solid waste stored in the 340-B Building Storage Area comes from 340 Facility operations and maintenance activities. Other WHC 300 Area solid waste generators occasionally use the 340 Facility as a staging area for solid radioactive waste transfers.

The 340 Facility ${ }^{\prime}$ consists of the following five buildings:

- 340 - control room, decontamination area, mechanical equipment room, change rooms, truck lock area, and an operator's office

- 340-A - above ground auxiliary RLWS tank storage

- 340-B East - railroad car loading station

- 340-B West - radioactive solid waste storage area (340-B East and 340-B West are one building)

- M0-036 - office trailer

- M0-741 - health physics technician (HPT) office and survey station.

The 300 Area RLWS, consisting of encased underground piping and ancillary equipment, connects the 340 Facility to individual Pacific Northwest buildings. The RLWS accepts radioactive liquids and mixed waste from the Pacific Northwest buildings. These liquids are gravity drained into the tanks within the 340 Building Vault. Transfers, if any, to the 340-A tanks require pumping. All 340 tanks (vault and above ground) and interconnecting piping have recently undergone and satisfactorily completed containment integrity checks (WHC 1996a).

\subsection{PROCESS/OPERATION}

The 340 Facility manages the RLWS. Radioactive waste is received via underground piping that connects the $324,325,326,327$, and 329 Buildings to the 340 Vault Tanks, or is transported to the facility in containers for addition to the 340 Vault Tanks. Containerized waste receipts outside the RLWS system enter the vault tanks either via the sump in the 340 decontamination area (see 2.3.1), or the drain (or pump TP-7) in the 340-B load-out facility (2.3.3). Recent examples of sources for containerized deliveries are lysimeter wastes and the 309 facility decon solutions. "Containers" may consist of anything from small carboys and 55-gallon drums to 5000 gallon tanker trucks.

${ }^{1}$ As differentiated from the 340 "Complex", which includes the 307 basins and the RPS connecting system. 
WHC-SD-WM-ISB-003, REV 1

The RLWS equipment is constructed of stainless steel pipe and tanks. Buried steel pipe is encased in fiberglass-reinforced plastic pipe. Each section of the RLWS passes through a concrete valve box, which allows for the isolation of the flow. These valve boxes are equipped with a sump, and sump leak detector.

The facility accumulates and stores waste in two $57 \mathrm{~kL} \mathrm{(15,000} \mathrm{gal)} \mathrm{below}$ ground tanks. One tank is always onl ine to receive waste, which allows the other tank to be isolated for transfer. The tanks, known as TK-1 and TK-2, are equipped with mechanical paddle agitators for mixing and centrifugal pumps for waste transfer. The liquid level in the tanks is recorded using a bubbler-type, liquid-level indicator. Each tank has two liquid-level alarm points: influent and high level. Should the tanks exceed the high-level point, they are equipped with an automatic function that transfers the contents of either tank to auxiliary storage, the six $30 \mathrm{~kL}(8,000 \mathrm{gal})$ above ground storage tanks located in the 340-A Building. In addition, TK-1 and TK-2 are connected by an overflow line. Should the transfer pump in one tank fail, the contents will overflow into the other tank.

Before transferring waste out of the 340 Facility, Operations schedules a rail tanker for delivery to the 340-B East Bujlding. The 340-B East Building is a pre-engineered metal building with a high roll-up door and a rail spur leading into the east side of the building. The building is designed to handle the $76 \mathrm{~kL}$ rail tankers used on the Hanford Site. To prepare waste for shipment, the transfer tank is isolated from incoming waste and sampled. The tank contents are agitated to homogenize the waste before samples are taken. The samples are sent to a laboratory for analysis. The sample results dictate how much waste may be safely loaded into a rail tanker and shipped to the 200 Area.

A rail tanker is then received into the east side of the 340-B Building, which has its own ventilation system. The tanker is dose rated and surveyed for radioactive contamination and, if it's acceptable, the tanker is connected to the RLWS. Although valves in the 340-A and 340-B Buildings are manually operated, much of the loadout operation - position vault valves, pump actions, and liquid level indication alarms - takes place remotely in the 340 Building control room. The rail tanker is loaded and shipped to the 204-AR unloading facility located in the 200 East Area for ultimate transfer to the doubleshell tanks.

Radioactive and mixed solid wastes are generated in the 340 Facility during the performance of routine operations, maintenance, and decontamination activities. Waste generated at the facility are typically low-dose rate waste, and are classified as low-level waste. The majority of the waste is packaged in $208 \mathrm{~L}$ (55-gal) drums and transported by truck to the 200 Area for burial or storage.

Internal waste transfers are done from the 340 Building control panel. Many of the transfers are automatic functions eliminating the need to establish valve line ups. Waste can be transferred between TK-1 and TK-2, from TK-1 or TK-2 to above ground auxiliary storage, and from above ground storage to TK-1 or TK-2. 


\subsection{BUILDINGS}

\subsubsection{Building}

The 340 Building is an above ground structure housing the 340 Facility operator office, change rooms, control room, equipment decontamination room with a sample hood, mechanical equipment room, and truck lock. Below ground, the 340 Vault contains two RLWS $57 \mathrm{~kL}(15,000 \mathrm{gal})$ tanks and a valve pit containing valves and piping partitioned off from the main vault. The above grade structure is steel and sheet metal attached to a steel frame mounted on a concrete foundation.

The 340 Building is provided with a ventilation supply system (including evaporative cooling and electric heating), and an exhaust system that serves all of the rooms except the control and mechanical equipment rooms. The exhaust system consists of two-stage high-efficiency particulate air (HEPA) filters, exhaust fan, and a stack that is located above the rest rooms.

The decontamination area contains a radioactive liquid waste (RLW) sample hood and a large open work area in the room for decontamination. A steel grating over a shallow concrete trough services the open work area. The trough drains into a sump in the corner of the bay. Wash solutions used for decontamination and water rinse are pumped from the sump directly to a vault tank.

The control room and a cabinet located next to the stack contain effluent monitoring and control instrumentation for the RLWS loadout system, valve controls, the main electrical control panel, and dryer for the compressed air system. The control room has heating and cooling capabilities and is accessed only through an outside door.

The small mechanical equipment room south of the control room contains instrument air compressors for the bubbler system, air operated valves, and vacuum pumps for the stack monitors.

The 340 Building Vault walls are constructed of concrete, with concrete shielded cover blocks and access holes. A hatch is provided in the roof allowing entry for inspection and maintenance. The valve pit, accessible through a separate hatch, is located next to the vault and contains valves, piping and a sample/backup pump. Hatches to the vault and valve pit have been covered with locked penthouses. The 340 Building Vault and vault tanks are serviced by a common exhaust system, which discharges through a stage of dust stop filters, two-stage HEPA filters, and two exhaust fans located just east of the vault. The capability exists for the addition of activated charcoal adsorbent into the exhaust treatment train. The charcoal filters were used in the past to help control potential Iodine-131 releases associated with activities in the 327 Postirradiation Testing Laboratory.

\section{3 .2 340-A Building}

The 340-A Building is constructed of steel panels attached to a steel frame mounted on a concrete foundation. The floor is set below grade level. The floor and lower portions of the walls are made of concrete. The floor contains a dry sump, which drains back to the 340 Building Vault Tanks. Six 
$30 \mathrm{~kL}(8,000 \mathrm{gal})$ stainless steel tanks are housed in the building to provide reserve capacity for RLW. There is no building ventilation and the tanks are ventilated through the vault ventilation system.

\subsubsection{0-B Building}

The east side of the 340-B Building houses a railroad car receiving and loadout station. The west side of the building has a 90-day solid mixed waste pad, and an area for radioactive solid waste, contained in steel drums and/or plywood or metal boxes. Other nonwaste items are also stored in the west side of 340-B Building. This building is constructed of steel panels mounted on a concrete foundation and is divided down the center by a concrete shielding wall extending out and around the south end of the building toward the east.

The railroad car loading station is in the east side of the building. The sump is located between the railroad tracks and drains to the 340 Building Vault Tanks. Flexible vent and fill 1 ines are provided that are coupled with the railroad car. Water flushing equipment is provided to clean the exterior of the railroad cars. The sump drain line valve is interlocked with the liquid waste transfer pumps to prevent inadvertent pressurization of the drain line and back filling of the sump.

The east side of the 340-B Building is serviced by a ventilation system (located in the west side of the building) consisting of a HEPA filter, vent fan, and stack. This ventilation equipment is primarily operated when a railroad car is in the loading station and connections are being made or broken, or the loading operation is in progress. The west side of the building does not have a supply or exhaust ventilation system. Electric ceiling heaters are used for heating when required.

\subsubsection{M0-036 Building}

The M0-036 building is a double-wide trailer inside the 340 Facility fencing west of the 340-B building. This trailer provides offices for engineering and operations personnel.

\subsubsection{M0-741 Building}

The M0-741 building is a small single-room trailer south of M0-036. This trailer provides an office for Radiological Control personnel, and contains two personnel contamination monitors (PCM-1B).

\subsection{RADIONUCLIDE AND HAZARDOUS MATERIAL INVENTORIES}

The 340 Facility does not routinely handle or store hazardous chemicals within the buildings. However, hazardous material is present in the radioactive liquid waste. A data base developed over a recent 5-year period 1989 through 1993 - for the 340 Facility recorded radionuclide and hazardous material concentrations for tank waste liquids before the waste was shipped from the 340 Facility via rail tank car to the 204-AR Unloading Facility in the 200 East Area. The data has been entered on a spreadsheet and the maximum value for each constituent was used. The radionuclide source term concentrations are shown in Table 2-1. Shipments made since this 5-year waste 
summary was first prepared for the development of Rev. 0 , have not exceeded Table 2-1 in terms of the maximum values depicted. These values are still considered valid for this Rev 1 ; and therefore continue to serve the purpose of demonstrating the conservatism of the bounding source term. The hazardous material source term is presented in Table 2-2.

\subsubsection{Vault}

The bounding source term for the 340 Building Vault Tanks assumes the sending tank contains its maximum $57 \mathrm{~kL}$ volume of a worst-case inventory. Because the RLW inventory is dependent on the work in Pacific Northwest laboratories, radionuclide concentrations may change. The worst-case inventory has been established based on the maximum inventory recorded in the past (Table 2-1). These historical values were increased to account for possible excursions, and these totals are shown in Table 2-3. Therefore, the facility inventory shown in Table 2-3 defines the bounding source term for liquid waste collected in a vault tank for transfer into a rail car. This bounding source term has been simplified to define total beta/gamma curies and total alpha curies in a full vault tank. The isotopic break-out depicted in Table 2-1 serves as the basis for substituting appropriate and realistic, worst-case nuclides for alpha or beta/gamma totals into the particular release scenarios and dose models used in various section 3.0 evaluations.

\subsubsection{Building}

The 340 Building inventory consists of radioactive and mixed solid waste and radioactive liquid waste in the decontamination area. The decontamination area in the 340 Building is a satellite accumulation area for solid waste, which is moved to the storage pad in the 340-B West Building. The sample sink and hood allow for processing samples from the vault tanks. Drains from the sample sink and hood return liquid to the sump. Decontamination solution drains through floor grating to trenches and then to the sump. The sump has a pump that transfers liquid waste back to the vault tanks.

\subsubsection{0-A Building}

The six cross-connected tanks in the 340-A Building are not currently used for waste storage. A heel of sludge exists in the portion of the tank below the piping connection to the tanks. An accumulation of fissile material (34 to $46 \mathrm{~g}$ ) is estimated to be in the sludge. This range reflects both: 1) the results of grab samples of sludge; and, 2) an estimate based upon process knowledge of the insolubility of plutonium and the amounts of plutonium that passed through the tanks when they were in continuous use. Water has been pumped into the tanks and the samples taken to characterize the sludge indicate that the heel cannot be removed by filling and draining tank and will not contribute to the total fissile inventory during an accident scenario.

\subsubsection{0-B Building}

The west side of the 340-B Building contains solid radioactive and mixed waste storage areas separated from the loadout facility by a $30 \mathrm{~cm}$ (12 in.) thick concrete shield wall. Waste from the $340 \mathrm{Facility}$ is collected and packaged where it occurs, then moved to the 340-B West Building for storage and shipment. Shipping records for solid waste generated in the 340 Facility 


\section{WHC-SD-WM-ISB-003, REV 1}

during the years 1989 through 1993 show that the maximum 208-L (55-gal) drum contained $3.08 \times 10^{-3} \mathrm{Ci}$ and the maximum plywood box contained $7.2 \times 10^{-4} \mathrm{Ci}$.

Higher curie levels were selected for the solid waste storage areas to define the bounding inventory. These higher curie values will allow the facility to operate without exceeding the approved operating envelope. Solid waste storage area values selected and used in the accident analysis are $10 \mathrm{C} i$ beta/gamma and $1.5 \mathrm{Ci}$ alpha as shown in Table 2-4. The accident analysis in Section 3.0 used these estimates of worst-case beta/gamma and alpha inventories for the onsite and offsite dose calculations.

The east side of 340-B is used for railroad tanker transfers and will contain RLW in the tanker during transfer operations. Occasionally a high-radiation, solid waste drum containing contaminated equipment (i.e., valve bodies, valve diaphragms, pump components, flanges, or sections of pipe) will be packaged in a shielded drum. Any such waste that would be considered a worker radiation exposure hazard is stored in the 340-B East Building to reduce exposure to workers. 
WHC-SD-WM-ISB-003, REV 1

Table 2-1. 340 Facility Radionuclide Inventory.

\begin{tabular}{|c|c|}
\hline Item & Maximum $\mathrm{Ci} / \mathrm{L}^{\circ}$ \\
\hline Total alpha & $7.40 \quad E-04$ \\
\hline Total beta & $2.77 \mathrm{E}-02$ \\
\hline${ }^{54} \mathrm{Mn}$ & $7.66 \quad E-07$ \\
\hline${ }^{60} \mathrm{Co}$ & $1.85 \mathrm{E}-06$ \\
\hline${ }^{90} \mathrm{Sr}$ & $1.07 \mathrm{E}-03$ \\
\hline $95 \mathrm{Zr}$ & $2.25 E-06$ \\
\hline${ }^{95} \mathrm{Nb}$ & $4.01 \mathrm{E}-06$ \\
\hline${ }^{99} \mathrm{Tc}$ & $4.73 \mathrm{E}-08$ \\
\hline${ }^{106} \mathrm{Ru}$ & $4.96 \mathrm{E}-05$ \\
\hline${ }^{125} \mathrm{Sb}$ & $3.96 \mathrm{E}-05$ \\
\hline${ }^{134} \mathrm{Cs}$ & $6.87 E-05$ \\
\hline${ }^{137} \mathrm{Cs}$ & $2.37 E-02$ \\
\hline${ }^{144} \mathrm{Ce}$ & $3.15 \mathrm{E}-04$ \\
\hline${ }^{152} \mathrm{Eu}$ & $4.49 E-03$ \\
\hline${ }^{154} \mathrm{Eu}$ & $7.90 \mathrm{E}-03$ \\
\hline${ }^{155} \mathrm{Eu}$ & $1.90 \mathrm{E}-03$ \\
\hline${ }^{182} \mathrm{Ta}$ & $1.14 \mathrm{E}-05$ \\
\hline${ }^{234} U$ & $1.50 \mathrm{E}-07$ \\
\hline $235 U$ & $1.88 \mathrm{E}-09$ \\
\hline $236 \mathrm{U}$ & $1.23 \mathrm{E}-08$ \\
\hline${ }^{238} U$ & $5.98 \mathrm{E}-08$ \\
\hline${ }^{238} \mathrm{Pu}$ & $2.72 \mathrm{E}-04$ \\
\hline${ }^{239 / 240} \mathrm{Pu}$ & $5.81 \mathrm{E}-05$ \\
\hline${ }^{240} \mathrm{Pu}$ & $7.85 \mathrm{E}-05$ \\
\hline${ }^{241} \mathrm{Pu}$ & $7.48 \mathrm{E}-03$ \\
\hline${ }^{242} \mathrm{Pu}$ & $2.35 \mathrm{E}-07$ \\
\hline${ }^{241} \mathrm{Am}$ & $6.26 \mathrm{E}-04$ \\
\hline $243 / 244 \mathrm{Cm}$ & $1.67 \mathrm{E}-06$ \\
\hline
\end{tabular}

"Based on rail car shipping concentrations, 1989 through 1993. 
Table 2-2. 340 Facility Hazardous Material Inventory.

\begin{tabular}{|c|c|}
\hline Item & Maximum $\mathrm{mg} / \mathrm{L}^{*}$ \\
\hline $\mathrm{Al}^{+3}$ & $3.20 E+03$ \\
\hline $\mathrm{As}^{+3}$ & $4.15 E+00$ \\
\hline $\mathrm{Ba}^{+2}$ & $1.14 E+01$ \\
\hline $\mathrm{HCO}_{3}^{-}$ & $5.38 E+02$ \\
\hline $\mathrm{Cd}^{+2}$ & $6.64 E+00$ \\
\hline $\mathrm{CO}_{2}$ & $5.50 E+02$ \\
\hline $\mathrm{CO}_{3}{ }^{=}$ & $2.91 E+01$ \\
\hline $\mathrm{Cl}^{-}$ & $3.40 E+03$ \\
\hline $\mathrm{Cr}^{+2}$ & $6.85 \mathrm{E}+01$ \\
\hline$F^{+}$ & $1.55 \mathrm{E}+01$ \\
\hline $\mathrm{OH}^{-}$ & $4.25 E+02$ \\
\hline $\mathrm{Pb}^{+2}$ & $8.72 E+01$ \\
\hline $\mathrm{Hg}^{+2}$ & $1.25 \mathrm{E}-01$ \\
\hline $\mathrm{NO}_{3}^{-}$ & $3.42 E+04$ \\
\hline $\mathrm{NO}_{2}^{-}$ & $3.01 E+03$ \\
\hline $\mathrm{PO}_{4}^{-3}$ & $7.27 E+03$ \\
\hline $\mathrm{Se}^{=}$ & $6.23 E+00$ \\
\hline $\mathrm{Ag}^{+1}$ & $4.46 E+00$ \\
\hline $\mathrm{Na}^{+}$ & $2.07 E+03$ \\
\hline $\mathrm{SO}_{4}=$ & $1.61 E+02$ \\
\hline TOC & $3.63 E+03$ \\
\hline
\end{tabular}

"Based on rail car shipping concentrations, 1989 through 1993.

$T O C=$ total organic carbon. 
Table 2-3. 340 Vault Tank Bounding Source Term.

\begin{tabular}{|l|l|c|}
\hline \multicolumn{1}{|c|}{ Isotope } & $\begin{array}{c}\text { Facility } \\
\text { Inventory } \\
\text { in Ci/L }\end{array}$ & $\begin{array}{c}\text { Ci/Tank } \\
57 \mathrm{~kL} \\
(15,000 \mathrm{ga})\end{array}$ \\
\hline Beta/Gamma & $6.90 \mathrm{E}-01$ & $3.93 \mathrm{E}+04$ \\
\hline Alpha & $1.16 \mathrm{E}-03$ & $6.61 \mathrm{E}+01$ \\
\hline
\end{tabular}

(1) As noted in Section 2.4.1, the historical maximum concentrations presented in Table 2-1 were further increased here (conservatively accounting for possible future excursions over past observances) to function as the bounding source term. Total alpha and beta/gamma values are presented because these gross parameters conform to the typical focus of both monitoring and laboratory screening analyses. In the next column these concentrations are in turn multiplied by the maximum vault tank capacity, 15,000 gallons.

Table 2-4. 340 Facility Soljd Waste Bounding Source Term. ${ }^{(1)}$

\begin{tabular}{|l|c|}
\hline \multicolumn{1}{|c|}{ Isotope } & $\begin{array}{c}\text { Worst-case } \\
\text { Inventory of Solid Waste } \mathrm{Ci}\end{array}$ \\
\hline Beta/Gamma & $10.00 \mathrm{E}+00$ \\
\hline Alpha & $1.50 \mathrm{E}+00$ \\
\hline
\end{tabular}

(1) As noted in Section 2.4.4, "Shipping records for solid waste generated in the 340 Facility during the years 1989 through 1993 show that the maximum 208-L (55-gal) drum contained $3.08 \times 10^{-3} \mathrm{Ci}$ and the maximum plywood box contained $7.2 \times 10^{-4} \mathrm{Ci}$. Higher curie levels were selected for the solid waste storage areas to define the bounding inventory. These higher curie values will allow the facility to operate without exceeding the approved operating envelope." Similar rationale to that given in the above Table 2-3 footnote explains use of gross, or total, radionuclide levels. 
WHC-SD-WM-ISB-003, REV I

This page intentionally without substantive content. 


\subsection{INTERIM SAFETY BASIS EVALUATION}

In order to limit risk from hazards and thereby conclude that the $\mathbf{3 4 0}$ Facility can be operated safely, the following sections reference existing safety analysis documents and provide information that identifies and evaluates hazards, identifies controls and/or mitigation systems, and identifies the necessary administrative controls and/or operational restrictions.

\subsection{HAZARD ANALYSIS}

This section summarizes the hazards of operating the 340 Facility using a PHA of the facility and its appurtenances. This section also evaluates the source terms - radiological and nonradiological - for the areas of the facility containing hazardous materials, determines the hazard categories for the areas within the facility, identifies the potential accident sequences based on the worst-case hazards from the PHA, estimates the potential consequences of the accidents, and provides a quantitative evaluation of the risk for the accidents.

\subsubsection{Hazard Categorization}

This section identifies the hazard category for each part of the 340 Facility using the bounding source term for that part of the facility. The hazards analysis categories for the 340 Facility are based on the "graded approach" and "facility segmentation" concepts of D0E-STD-1027-92. The "graded approach" ensures that the thoroughness of the documentation be graded or proportioned commensurate with the magnitude of the hazards, the complexity of the facility, and the stage or cycle of the facility. The "facility segmentation" concept in accordance with DOE-STD-1027-92 applies to inventories of hazardous materials where facility features preclude collocating the material and material interaction during a postulated accident (the Fire Hazards Analysis [Roberts 1995] also supports facility segmentation). There is a physical separation between buildings in the 340 Facility. Also, the 340-B Building has a concrete wall that separates the building into a 340-B East area and a 340-B West area. These physical separations and concrete wall provide barriers between the hazardous sources that prevent the interaction of hazardous materials during a postulated accident. The hazard categorization is based on radiological hazards in accordance with D0E-STD-1027-92.

3.1.1.1 Radioactive Liquid Waste System Hazard Category. The RLWS hazard category is established in the following subsections.

340 Vault Tanks - A spray release, while filling the railroad tank car from one of the 340 Vault Tanks, is the credible accident considered for hazard category determination. The $\mathrm{Ci} /$ threshold quantities modified $\left(\mathrm{TQ}_{\mathrm{m}}\right)-\mathrm{Ci}$ for the vault tanks, based on the modified Hazard Category 2 threshold quantities of one vault tank $(57 \mathrm{~kL})$ is shown in Table $3-1$ (note discussion in Section 3.1.2). The total $\mathrm{Ci} / \mathrm{TQ}_{\mathrm{m}}-\mathrm{Ci}$ of $2.66 \times 10^{-02}$ is less than 1 , placing the vault tanks within Hazard Category 3 . 
340-A Tanks - The 46 fissile grams in the 340-A Tanks, using the specific activity for ${ }^{239} \mathrm{Pu}$ of $6.2 \times 10^{-2} \mathrm{Ci} / \mathrm{g}$ becomes $2.85 \mathrm{Ci}{ }^{239} \mathrm{Pu}$, with a Hazard Category 2 threshold quantity (TQ) of $5.6 \times 10^{1} \mathrm{Ci}$ giving a $2.85 \mathrm{Ci} /$ $5.6 \times 10^{1}=5.1 \times 10^{-2} \mathrm{Ci} / \mathrm{TQ}-\mathrm{Ci}$, which is less than 1 , placing the $340-\mathrm{A}$ Tanks in Hazard Category 3.

3.1.1.2 Solid Waste Area Hazards Category. A solid waste fire that would consume the entire inventory (Table 3-2) results in a total Ci/TQ-Ci of $2.72 \times 10^{-02}$, based on Hazard Category 2 threshold quantities per DOE-STD-1027-92, placing the solid waste in Hazard Category 3.

\subsubsection{Hazard Categorization Methodology}

If a facility contains greater than Hazard Category 2 TQ, as defined in DOE-STD-1027-92 and shows the potential for significant onsite consequences, the facility is defined as Hazard Category 2. Attachment 1 of DOE-STD-1027-92 notes that if the ratio of the quantity of each isotope to its Hazard Category $2 \mathrm{TQ}$ is $\leq 1$ and the sum of the ratios for each isotope in the facility is $\leq 1$, then the facility is Hazard Category 3 . If the sum is greater than 1 , the facility is defined as Hazard Category 2. The following equation defines how the sum of the ratios is calculated:

$$
\underset{\text { Sutios }}{\text { ratiof }}=\frac{j}{i=1} \quad \frac{\text { Inventory quantity of isotope }}{\text { Category } 2 \text { threshold quantity of isotope }}
$$

3.1.2.1 Radioactive Liquid Waste System. The hazard categorization calculations for the 340 Vault Tanks (Table 3-1) are based on DOE-STD-1027-92, paragraph 3.1.2, and the spray-release accident described in Section 3.1.4.1 of this document. DOE-STD-1027-92 allows for modification of the threshold limit values by replacing the release fraction assumed in D0E-STD-1027-92 with the release fraction calculated for the worst-case unmitigated accident. The material at risk consists of the contents of one of the vault tanks $(57 \mathrm{~kL})$. The calculated respirable volume released in the spray is $5.11 \times 10^{-4} \mathrm{~kL}$ (Appendix $B$ ). The release fraction is determined by dividing the respirable volume released by the material at risk $\left(5.11 \times 10^{-4} \mathrm{~kL} / 57 \mathrm{~kL}=8.96 \times 10^{-6}\right)$. The release fraction $\left(8.96 \times 10^{-6}\right.$ ) was divided by .001 (the release fraction assumed for liquids on page A-9, Item 4 of DOE-STD-1027-92) to give $8.96 \times 10^{-3}$. The Hazard Category 2 TQ values were divided by $8.96 \times 10^{-3}$ to obtain the modified threshold values $\mathrm{TQ}_{\mathrm{m}}$. The modified threshold values $\mathrm{TQ}_{\mathrm{m}}$ were used to calculate the $\mathrm{Ci} / \mathrm{TQ}_{\mathrm{m}}$ for ${ }^{90} \mathrm{Sr}$ and ${ }^{239} \mathrm{Pu}$ in Table $3-1$.

The sum of ratios of the $\mathrm{C} i / \mathrm{TQ}_{\mathrm{m}} \mathrm{s}, 2.66 \times 10^{-2} \mathrm{Ci}$, is less than 1.0 and places the RLWS in Hazard Category 3. Table 3-3 contains the plutonium equivalent curie (PE-C $i$ ) calculations based on the alpha inventory in Table 2-1.

The 340-A Tanks were considered separately from the 340 Vault tanks because the immobility of the inventory precludes it from consideration in the vault tank accident scenario. However, it still contributes to the hazard category. 
3.1.2.2 Solid Waste. The bounding radiological source term for the solid waste is shown in Table 2-4. The isotopes in Table 2-4 were used in an accident scenario that involved a solid waste fire that consumes the entire inventory. Dividing the curie inventory by the Hazard Category 2 TQ of DOE-STD-1027-92 results in a total $\mathrm{Ci} / \mathrm{TQ}-\mathrm{Ci}$ of $2.72 \times 10^{-02}$ (Table $3-2$ ). The $\mathrm{Ci} / \mathrm{TQ}-\mathrm{C} i$ is less than 1 , placing the solid waste in Hazard Category 3 .

\subsubsection{Preliminary Hazards Analys is}

The 340 Facility PHA shown in Table $3-4$ systematically 1 ists the hazard/energy sources for the facility, identifies the potential accident and sequence of events leading up to the accident, and tabulates the target/potential consequences of the accident. Table 3-4 includes both engineered and administrative mitigating features, as applicable, for each potential accident. Table 3-4 also provides an estimate of the qualitative accident severity levels using the annual frequency and severity category descriptions in Table 3-5. From the longer list of accidents in Table 3-4, a small number of worst-case accidents were selected that represent accidents having the highest probability and greatest severity coupled with the highest dose consequences. These accidents are then evaluated for both onsite and offsite dose consequences. By demonstrating that the 340 Facility can be operated safely, assuming worst-case unmitigated releases from the highest severity/highest probability accidents, it can be concluded that the facility can also be operated safely assuming unmitigated accident releases of the other lower probability/lower severity accidents.

The worst-case accidents having the highest severity/highest probability that were selected for further evaluation in this section include:

- A spray release occurs upon failure of the pipe or pipe connection while pumping liquid into a railroad tank car (Table 3-4, II.A.5)

- A fire occurs in the 340-B West dry-waste storage area (Table 3-4, I.A.2.g).

3.1.3.1 Fire. A fire in one of the 340 Facility buildings could result in equipment and structure damage, and personnel injury. There is also a potential for radiological and chemical release based on inventory. Flammable quantities of liquids are not allowed in the RLWS, which eliminates the potential for a fire in the tanks in 340-A and the vault. The 340 Facility contains solid mixed waste in the 340 Building and the $340-B$ Building. The 340 Building has a fire detection and suppression system. The 340-8 Building only has fire detection. The majority of the solid waste is stored in the 340-B West Building with some waste in the 340-B East Building. The amount of solid waste stored in the 340-B East Building is minimal and nonroutine. The release due to a solid waste fire in the 340 Building or 340-B East Building would be insignificant, compared to a solid waste fire in 340-B West Building.

3.1.3.2 Corrosion. The 340 Facility does not provide long-term storage of solid or liquid waste drums, eliminating the potential for containment failure, as a result of corrosion. There is a potential for corrosion in the RLWS pipelines, the 340 Vault Tanks, and the 340-A Tanks. However, the pipelines are encased, the vault tanks have a concrete vault, and the $340-A$ Tanks have a concrete sump draining to the vault tanks. Encasement, vault, 
and sump leak detectors are also present. Corrosion presents an insignificant potential for hazard to the onsite/offsite person.

3.1.3.3 Potential Kinetic Energy. There is a potential for solid or liquid waste release as a result of drum/container impacts by heavy equipment, sharp/hard equipment, or by dropping. However, only low levels of waste are allowed and the effect of a spill would be local with a minimal airborne release. A helicopter or plane crash would also produce minimal airborne release and is considered extremely unlikely. The highest potential for an airborne release would be a pipe failure while pumping liquid waste to the tank car. This failure could produce a spray release and affect the onsite/offsite individual.

3.1.3.4 Natural 0ccurrences. Regarding natural forces criteria, early Hanford Site structures were designed for static, vertical live and dead loads, and have limited seismic resistance because the Site was classified as a low-intensity, low-frequency earthquake zone. Later, a classification was made to Zone $2 B$ on the Uniform Building Code Seismic Risk Map, and currently the Site is considered an area of moderate to low seismicity (Uniform Building Code, UBC 1991). Some seismic resistance is inherent in structures because of design for winds (lateral forces), nonstructural elements (reserve strengths), stability requirements, limits on deflections, and safety factors included in design and working stress values for materials. Buried structures have considerable inherent earthquake resistance because they are constructed to support the backfill, and the backfill will restrict relative motions between the structures and ground during an earthquake.

The result of natural occurring events such as floods, earthquakes, wind and volcanic activity present only minor releases and are considered insignificant compared to the spray release of the RLWS inventory.

3.1.3.5 Stack Release. The 340 Vault and vault tanks are serviced by a common exhaust system discharging through a stage of dust stop filters, two stages of HEPA filters, and two exhaust fans. The capability exists for the addition of activated charcoal adsorbent into the exhaust treatment train. Filter change-out occurs on an as needed basis indicating that neither radionuclide buildup nor dust buildup on the filters is significant. A recent radiation measurement for the HEPA filter housing of $80 \mathrm{mrem} / \mathrm{hr}$ after more than 3 years of continuous operation further suggests that radiation buildup in the HEPA filters is moderate. Therefore, HEPA filter system degradation or failure is not a significant hazard and is bounded by the spray release accident. The charcoal filters were used in the past to help control potential $I-131$ releases associated with activities in the 327 Postirradiation Testing Laboratory.

3.1.3.6 Loss of Utilities. Loss of electrical utilities would result in the loss of stack fans, monitoring, transfer pump operation, tank level indication, and alarm capabilities. Although active ventilation and monitoring would be lost, passive ventilation through the HEPA filters would exist. Loss of transfer pump operations would only eliminate the potential for a spray leak. Loss of tank level indication and alarm capabilities would not affect the integrity of secondary containment. Also, waste handling operation would be curtailed. Therefore, there would be no significant safety related hazard to the onsite/offsite personnel. 
Loss of electricity could result in a 340-A Building RLWS pipe rupture during freezing weather. The liquid waste would drain to the 340-A sump where the leak would be detected. The 340-A sump drains to vault tank 2 and thus, there would be no release.

Loss of process water would result in the loss of pump seal water, which could burn up the pumps when running. The failure of the pumps would not allow liquid transfers to take place. However, the pumps are interlocked to shut down on low seal water pressure. This is not a significant hazard to the onsite/offsite person.

3.1.3.7 Radiation. High-level radiation from RLWS inventory in the 340 Vault Tanks, the 340-A tanks, and 340-B East Building could result in high personnel exposure. Area radiation monitors provide warning on high radiation. Prior approval and notification of waste transfers are required, and access is restricted in high-radiation areas. High-level radiation from solid waste in either the 340 or $340-B$ West buildings is monitored by the Health Physics Technician (HPT). High-level radiation areas are controlled and present an insignificant hazard to the onsite/offsite person.

The 340 Facility maintains less than 177 FGE to maintain its status as an isolated facility per WHC-CM-4-29 and the 340 CSER (Miller, 1996). The 340 Facility administratively controls criticality concerns in accordance with WHC-CM-4-29 and DOE Order 5480.24, Nuclear Criticality Safety. Therefore, adequate criticality controls are maintained and additional controls are not necessary.

\subsubsection{Accident Scenarios and Consequences}

The types of operating hazards that could cause a significant release from the 340 Facility are limited. Table 3-6 contains a listing of the potential hazards for this facility, including a listing of the mitigating features and administrative controls used to ensure safe operation. Considering the preliminary hazards identified in Table 3-4 and the potential operating hazards in Table 3-6, a spray release in the 340-B East Building while pumping to a tank car and a solid waste fire in 340-B West Building are the worst-case potential accidents identified for further evaluation.

\subsubsection{Spray Release from 340 Vauit Tanks. A spray release while filling} the railroad tank car from the 340 Vault Tanks is the most likely significant accident. Because the vault tanks are not under pressure and are underground, a spray release from the piping can only occur while the transfer pumps are operating. One tank must be valved to receive waste and automatic transfers from one tank to another do not occur while filling the tank car. Therefore, when one tank has been emptied, it is necessary to shut down the transfer pump and switch the valving to the other tank, making the maximum duration of a spray leak the time it takes to pump out one full tank. Also, because of administrative sampling requirements, typically only the contents of a single tank are transferred per railcar shipment.

Each of the vault tanks have a $57 \mathrm{~kL}(15,000 \mathrm{gal})$ maximum capacity, and the pump has a capacity of $380 \mathrm{~L} / \mathrm{min}(100 \mathrm{gal} / \mathrm{min})$ with a head of $16 \mathrm{~m}$ $(53 \mathrm{ft})$. The maximum time a spray release can occur is $150 \mathrm{~min}(15,000 \mathrm{gal}+$ 
(53 ft). The maximum time a spray release can occur is $150 \mathrm{~min}(15,000 \mathrm{gal}+$ $100 \mathrm{gal} / \mathrm{min}=150$ minutes $)$. This time will be used for the spill ignoring the periodic leak inspections.

The pump head of $16 \mathrm{~m}$ (23 psi) and friction losses for the pipeline crack were used in a spreadsheet to calculate the total liquid released and the respirable liquid released using the equations in WHC-SD-GN-TI-30003

(WHC 1992), see Appendix B. No credit was taken for loss in head pressure from the pump to the tank car, about $4.5 \mathrm{~m}(15 \mathrm{ft})$, the building, or leak inspections. The spreadsheet calculations for a pipeline crack $7.62 \mathrm{~cm}$ ( 3 in.) long and $1.94 \times 10^{-2} \mathrm{~cm}\left(7.65 \times 10^{-3}\right.$ in.) wide gives a $1.07 \mathrm{~m}^{3}$ $(275 \mathrm{gal})$ spray release, with a respirable liquid release of $5.11 \times 10^{-4} \mathrm{~m}^{3}$ $(0.132 \mathrm{gal})$. Using the bounding source term, as established in Section 2.4, the $X / Q$ values from the Hanford Environmental Radiation Dosimetry System Software System, GENII (Napier et al. 1988), dose-consequence calculations (Appendix $C$ and Table 3-7), and the respirable release from above, Table 3-8 shows the onsite and offsite dose estimates of 3.92 rem EDE and $3.30 \times 10^{-01}$ rem EDE, respectively.

The corresponding release of chemicals for the spray-leak accident is shown in Appendix $D$. The release flow rate of $5.68 \times 10^{-8} \mathrm{~m}^{3} / \mathrm{s}$ was multiplied by the onsite $X / Q, 4.21 \times 10^{-2} \mathrm{~s} / \mathrm{m}^{3}$ and offsite $X / Q, 3.77 \times 10^{-3} \mathrm{~s} / \mathrm{m}^{3}$, and the highest hazardous material inventory $\left(\mathrm{NO}_{3}{ }^{-}, 3.42 \times 10^{4} \mathrm{mg} / \mathrm{L}\right)$ to obtain the release in $\mathrm{mg} / \mathrm{m}^{3}$. The chemicals released in the spray are well below ERPG levels, per WHC-CM-4-46.

3.1.4.2 Fire Involving Solid Waste. The west side of the 340-B Building is both a 90-day solid mixed waste pad, and a radioactive waste storage area, separated from the loadout facility by a $30 \mathrm{~cm}$ (12") concrete shield wall. Waste from the 340 Facility is collected and packaged where it occurs, then moved to 340-B West Building for shipment. The solid waste stored on the 340 Building 90-day hazardous waste pad and the 340-B West Building 90-day solid mixed waste pad typically consists of cleaning materials, personal protective equipment and clothing, worn out equipment, material from cleanup activities, and tools that cannot be completely decontaminated and released.

Because the waste is solid and stored in boxes or drums the worst-case accident would be a fire, assuming sufficient combustible contents. Possible onsite and offsite releases were estimated, using an airborne-release fraction (ARF) of $5 \times 10^{-4}$ from Increment of Analysis: An Estimate of Airborne Release of Plutonium From Babcock and Wilcox Plant As A Result of Severe Wind

(Mishima et al. 1978). The bounding source term established in Section 2.4, was used with the ARF to obtain onsite and offsite doses as shown in Table 3-9. The estimated total dose onsite is 3.24 rem EDE and the estimated total dose offsite is $2.72 \times 10^{-01}$ rem EDE.

\subsubsection{Risk Evaluation}

Table 3-8 provides the dose consequence for a liquid spray release from the 340 Vault Tank while pumping to the railroad tanker. The conditions for the release are conservative in that no credit has been taken for the building enclosing the tanker, nor the loss in head pressure from the pump to the tanker; and it is estimated that an entire vauit tank volume will be pumped without any awareness of the leak during this $2 \frac{1}{2}$ hour operation. The onsite 
and offsite doses are based on a full tank (57 kL) of the worst-case source term (Table 3-8). Figure 3-1 shows a comparison of the total dose consequences to the risk-acceptance guidelines (A Model for Estimating the Release Rate of Aerosol Droplets From Pressurized Liquid Leaks, WHC 1992) for an Annual Frequency Category of $1.0 \times 10^{-5}$. Both the onsite and offsite doses are within the risk-acceptance guidelines.

The dose consequences for the worst-case solid waste fire in the 340-B West Building is shown in Table 3-9. Conservatism has also been applied here, by calculating the entire inventory of steel drums and fire retardant boxes to be consumed in the fire and taking no credit for the building. The onsite and offsite doses are based on the worst-case source term (Table 2-4). Figure 3-1 shows a comparison of the total dose consequences to the risk-acceptance guidelines for an Annual Frequency Category of $1.0 \times 10^{-3}$. Both the onsite and offsite doses are below the risk-acceptance guidelines.

The release fraction uncertainties can be obtained from DOE-HDBK-3010-94. This ISB document uses the bounding release fractions for the dose estimates. For a solid waste fire the bounding release fraction is 5 E-04 and the median release fraction is 8 E-05 (DOE-HDBK-3010-94, p. 5-1). The expected onsite and offsite doses, using the median release fraction, is, respectively, 0.518 rem and 0.0435 rem (verses the bounding values of 3.24 rem and 0.272 rem, respectively). The bounding values, therefore, are 6.25 times higher than the expected values and this difference represents the uncertainties for the consequences. The uncertainty for the frequency value, $1 \mathrm{E}-03$, is the range 1 E-04 to $1 \mathrm{E}-02$. The fire accident was judged to be an unlikely event with a frequency range of 1 E-04 to 1 E-02. The value 1 E-03 is in the middle and was chosen for Figure 3-1 to show the comparison to the guideline values.

The above calculations show that neither a spray release in 340-B East Building, nor a solid waste fire in 340-B West Building would exceed the 5 rem EDE onsite or the 0.5 rem EDE offsite limits. The 340 Facility continuously receives and transports waste and thus the inventory may change. To ensure that onsite/offsite limits are not exceeded during a spray-release incident, the RLWS inventory must be known to be within the bounding source term (see 3.2.2.3.2) before loadout operations are initiated. Also, the inventory of solid wastes must be controlled within the solid waste bounding source term (see 3.2 .2 .3 .3 ).

\subsection{HAZARD CONTROLS}

This section describes the physical and administrative systems used for the control and/or mitigation of the 340 Facility accidents and events. There are no Safety Class nor Safety Significant systems in the 340 Facility.

\subsubsection{Structures, Systems and Components (SSC)}

3.2.1.1 340 Building. The 340 Building is an above ground structure of steel and sheet metal attached to a steel frame mounted on a concrete foundation. The 340 Vault is constructed of concrete with cover blocks, access holes, and hatches. 
The 340 Building truck lock, control room, and decontamination room are protected with smoke and temperature detectors and automatic sprinklers. The smoke detectors and the sprinkler systems alarm locally and at the central dispatch in the 200 Area. Criteria, as established by the National Fire Protection Association Codes, were used for location of the above systems.

The 340 Building is provided with a ventilation supply system, an evaporative cooling system, an electric heating system, and an exhaust system servicing al1 of the rooms except the control and mechanical equipment rooms. The exhaust system consists of two-stage HEPA filters, an exhaust fan, and a stack that is located above the rest rooms. Airflow from the decontamination area hood, sink, and sump pass through an additional stage of HEPA filters before the two-stage HEPA filters.

The 340 Vault and Tanks are serviced by a common exhaust system, discharging through a stage of dust stop filters, two-stage HEPA filters, and two exhaust fans located just east of the vault. The capability exists for the addition of activated charcoal adsorbent into the exhaust treatment train. The charcoal filters were used in the past to help control potential I-131 releases associated with activities in the 327 Postirradiation Testing Laboratory. Some ventilation alarms are contained in panels near the stack. All other alarms signal in the control room.

A process radiation detector is located in Valve Box 9 . It provides local alarms and remote alarms at the 340 Building Control Room Annunciator Panel and the 310 TEDF control room. The detector provides a means of monitoring for a change in the radiation level or movement of radioactive liquids and also provides an alarm on high radiation levels.

Vault tank high liquid-level alarms exist that aid in preventing tank overflow. There are also influent alarms that will alarm before the high-level alarms (variable-level alarms are normally slightly above the current level in the tank). In addition, overflow is prevented by a high-high set point that will automatically pump the waste to the $340-A$ Tanks. These alarm at the 340 control panel and remotely in 310 TEDF. Finally, there is an overflow leg between the two vault tanks so they will overflow to each other. In the event of a tank or piping leak, the concrete vault will temporarily contain up to $360 \mathrm{~kL}(94,000 \mathrm{gal})$ of liquid. The vault is equipped with a leak detector located at the sump and a sump pump.

There are also liquid-level alarms in the RLW 1 ines at the 325 and 327 Buildings. They alarm locally and at the 310 TEDF, if water backs up in the RLW 1 ine.

3.2.1.2 340-A Building. The 340-A Building is constructed of steel panels attached to a steel frame mounted on a concrete foundation. The floor is set about $1 \mathrm{~m}$ below grade level. The floor and lower portions of the walls are made of concrete. The floor contains a dry sump that drains back to the 340 Vault Tanks. Six $30 \mathrm{~kL}(8,000 \mathrm{gal})$ stainless steel tanks are housed in the building to provide reserve capacity for RLW. They are valved to be used as one but also can be used singly. A leak detector is located in the trench to the sump. The tanks are ventilated through the vault ventilation system.

An area radiation monitor is located inside the west door, which is the 
main door. It provides local alarms and remote alarms at the 340 Building Control Room Annunciator Panel and the 310 TEDF. The monitor provides a means for monitoring a change in the radiation level or movement of radioactive liquids and also provides an alarm on high radiation levels.

3.2.1.3 340-B Building. The 340-B Building is constructed of steel panels mounted on a concrete foundation. The building is divided down the center by a $30 \mathrm{~cm}$ (12 in.) thick concrete shielding wall.

The east side of the building is serviced by a ventilation system located in the west side of the building, consisting of a pre-filter, HEPA filter, exhaust fan, and stack; operated only when needed (see 2.3.3).

The 340-B Building is equipped with smoke detectors that alarm locally and at the central dispatch in the 200 Area. Installation locations were established by guidelines in the National Fire Protection Codes.

3.2.1.4 340 Facility Compliance with Codes, Standards, and Regulations. The core 340 Facility was built and commissioned for radioactive service in 1952, with several additions acquired over the years. The facility met the applicable codes, standards, and regulations at the time of construction. The facility has been, and continues to be upgraded to meet changing emission and regulatory requirements. The facility and operations are routinely audited to ensure compliance with the intent of meeting applicable codes, standards, and regulations. As part of the overall 300 Area upgrade, the RLWS has been renovated to improve environmental protection and to further reduce potential for personnel exposure. Although not required to mitigate, prevent, or control design base accidents, the systems listed in Table 3-10 provide enhanced safety in the operation under both routine and abnormal situations.

\subsubsection{Administrative Controls/Operational Restrictions}

3.2.2.1 Administrative Controls. The 340 Facility operations are conducted in accordance with various operational and administrative documents that establish formal programs to ensure compliance with applicable DOE Orders. Where necessary, instructions and procedures are prepared to translate the general requirements of DOE and WHC directives into specific guidance and limits to be observed by the operating staff.

3.2.2.2 General Westinghouse Hanford Company Administrative Controls. WHC policy and standard practices regarding specific facets of ongoing operational activities are set forth in manuals and procedures approved by the WHC President or designee. Several of the more significant documents that constitute part of the WHC system for administrative controls are included in the following:

- HSRCM-1, Rev. 2, Hanford Site Radiological Control Manual

- WHC-EP-0063, Solid Waste Acceptance Criteria, (WHC 1993)

- WHC-EP-0846, Waste Specification System, (WHC 1995b)

- WHC-IP-0263-340, Building Emergency Plan, (WHC 1995a)

- WHC-IP-1000, 300 Area Liquid Effluent Facilities Administration

- WHC-CM-1, Company Policies and Charters

- WHC-CM-1-3, Management Requirements and Procedures

- WHC-CM-1-5, standard Operating Practices 
-WHC-CM-1-10, Safety Manua 1

- WHC-CM-1-11, Industrial Hygiene Manual

- WHC-CM-2-14, Hazardous Materials Packing and Shipping

- WHC-CM-4-1, Fire Protection Program

- WHC-CM-4-2, Quality Assurance

- WHC-CM-4-29, Criticality Safety Procedure

- WHC-CM-4-33, Security

- WHC-CM-4-34, Nuclear Material Control Accountability

- WHC-CM-4-41, Fire Protection Program Manual

- WHC-CM-4-43, Emergency Management Procedures

- WHC-CM-5-16, Solid Waste Management

- WHC-CM-6-1, Standard Engineering Practices

- WHC-CM-7-5, Environmental Compliance.

\subsection{Facility Waste Management Facility Administrative}

Controls. Operation of the 340 Facility is conducted in accordance with operating, maintenance, and administrative procedures and programs approved by WHC management. These procedures and programs are incorporated into 340 Facility operating procedures and the 300 Area Liquid Effluent Facilities Administration Manual (WHC 1994b). This manual is consistent with and implements the requirements of the documents listed above. Any modification that would change the facility status as a nuclear facility would be an unreviewed safety question and would be documented in subsequent revisions or supplements to this ISB.

Specific procedural and administrative controls are provided that cover:

- Building emergency preparedness and response procedures

- Equipment and process operating procedures

- Maintenance and inspection procedures

- Staff qualification and training programs - includes training for building personnel in the areas of criticality safety, radiation protection, industrial safety, job hazards, security, operating and emergency procedures.

These controls are implemented at the work stations (point of operation) by:

- Qualifications and demonstrated proficiency for job assignment

- The 340 Facility procedures and work packages that contain the taskspecific Job Safety Analysis and Radiological Work Permits.

3.2.2.2.2 Audit Program. Adherence to established procedures and the adequacy of those procedures is verified continuously by a program of audits and inspections.

The audit program is accomplished by the following:

Self Audit - The manager of 340 Facility Operations is responsible for ensuring that audits and inspections of facility operations are done regularly 
to identify and correct deficiencies. WHC-IP-1000, Section 1.8, "Management Assessment Program", establishes the basis for scheduling assessments.

Safety - Safety is responsible for conducting regular audits to verify the adequacy of the operational procedures, records, and conformance with operating limits.

Quality Assurance - The Quality Assurance department is responsible for periodic audits of quality systems to verify that facility operations are in compliance with WHC-CM-4-2.

3.2.2.3 Operational Restrictions. This section identifies the interim operational safety requirements (IOSR) for the 340 Facility. The IOSR are administrative controls that define limits to assure compliance within the classification of a Hazard Category 3 facility. These limits replace the previous operating limits.

\subsection{Facility Maximum Fissile Limit.}

Applicability - All storage, handling, or processing of radioactive waste in the 340-Complex.

Objective - To maintain a fissile materials inventory compliant with the classification of an isolated facility per WHC-CM-4-29 and the CSER 94-012: Criticality Safety Evaluation Report for 340 Facility (Miller, E.M., 1996) which supports the isolated facility classification. It should be noted the 340 CSER also documents that solid and Tiquid waste systems could be regarded as separate systems due to physical, isolating barriers. If the system were to be managed separately the solid waste system would be classified as "exempt".

Requirement - The ${ }^{239} \mathrm{Pu}$ FGE equivalent quantities within the 340 Facility will be maintained at less than 177 FGE.

Surveillance - An inventory of the FGE within the 340 Facility will be maintained to demonstrate compliance with the requirement. The administrative program assigns responsibility and establishes programs for sampling and surveillances which verify adequate inventory accountability.

Basis - The facility criticality safety status as an isolated facility is in accordance with WHC-CM-4-29. The corresponding maximum fissile inventory value is based upon a fraction of the minimum critical mass (MCM). This MCM is in turn based upon $100 \% \mathrm{Pu} 239$ aqueous metal solution, optimum water moderation, full water reflection, optimum concentration ( $31 \mathrm{~g} \mathrm{Pu} / \mathrm{L}$ ) and spherical geometry. By contrast, the large, cylindrical 340 tanks contain much lower fissile concentrations, along with other chemical compounds which serve to absorb neutrons (e.g., chlorides, nitrates, and nitrites).

Recovery - In the event the requirement is not met, notification will be immediate and will include the 340 Facility manager and the manager of Criticality and Radiological Analysis. The cause of the event will be determined and a course of action to correct the problem will be implemented. A determination will be made if a continued classification as a Hazard Category 3 facility is valid. 
Audit Point - Sample data used to determine FGE amounts and inventory lists of FGE amounts will be retained for a minimum of 15 months.

\subsection{Radioactive Solid Waste Storage Limit.}

Applicability - All storage, handling, or processing of solid radioactive waste in the 340 -Complex subject to fire.

Objective - To prevent significant onsite and offsite dose consequences in the event of a fire by maintaining the solid radioactive materials inventory at a level validating the solid waste storage areas as Hazard Category 3.

Requirements - Dispersible radioactive materials packaged in solid waste in fire retardant boxes or drums will not exceed the following limits:

$$
\text { - Alpha emitters } \quad 1.5 \mathrm{Ci}
$$

Surveillance - An inventory of the radioactive materials present will be maintained that demonstrates compliance with the requirement.

Basis - The accident analysis for a fire involving radioactive waste materials (Section 3.0) with the above maximum inventory has shown that the resultant consequences, without credit for mitigating features, meets the criteria for a Hazard Category 3 facility. The analysis shows that the estimated fire consequences for a total solid waste inventory of $11.5 \mathrm{Ci}$ would be 3.24 rem EDE onsite and $2.72 \times 10^{-1}$ rem EDE offsite.

Recovery - In the event the requirement is not met, notification will be immediate and will include the 340 Facility manager. The cause of the event will be determined and a course of action to correct the problem will be implemented. A determination will be made if a continued classification as a Hazard Category 3 facility is valid.

In the event that the inventory is not maintained, the facility inventory of radioactive materia] will be immediately determined and corrective action taken to prevent reoccurrence

Audit Point - Storage/disposal records of inventory lists of radioactive materials will be retained for a minimum of 15 months.

\subsection{0-B Railroad Tank Car Loadout Restrictions.}

Applicability - 340 Facility RLWS transfer operations to 340-B East Building for railroad tanker loadout.

Objective - To prevent significant onsite and offsite consequences in the event of a spray leak by maintaining the liquid radioactive materials inventory at a level validating the vault tanks as Hazard Category 3.

Requirement - If the sending tank exceeds the following criteria, RLWS transfer operations to the 340-B East Building for railroad tanker loadout are prohibited until Engineering provides isotopic calculations that verify the 
WHC-SD-WM-ISB-003, REV 1

inventory to be transferred will not exceed the onsite/offsite doses and Hazard Category 3 Limits.

- Total Alpha

$66 \mathrm{Ci}$

- Total Beta/Gamma $39 \mathrm{kCi}$.

Surveillance - Tank inventory data, by sample analysis and calculations, will demonstrate compliance with the requirement before transfer to the railroad tanker.

Basis - The accident analysis for a spray release (Section 3.0) of radioactive liquid waste from the vault tanks with the above maximum inventory has demonstrated that the resultant onsite and offsite consequences, without credit for mitigating features, classify the 340 Facility as Hazard Category 3. The spray-release accident analys is shows that the estimated release consequences from a full vąult tank inventory of $1.07 \mathrm{~m}^{3}$ released (the respirable release is $5.11 \times 10^{-4} \mathrm{~m}^{3}$ ) is $3.92 \mathrm{rem} E D E$ onsite dose and $3.30 \times 10^{-1}$ rem EDE offsite.

Recovery - In the event the requirement is not met, transfer operations will cease, notification will be immediate, and will include the 340 Facility manager. Restrictions on quantity transferred or isotopic calculations from engineering are required for continuation of transfer operations. The cause of the event will be determined and a course of action to correct the problem will be implemented.

Audit Point - Vault tank sample data and waste transfer records/memo will be retained for a minimum of 15 months.

\subsubsection{Institutional Safety Programs}

3.2.3.1 As Low As Reasonably Achievable. In compliance with DOE Orders and to support radiation protection, WHC has established a company-wide ALARA program applicable to the pre-operational, operational, and post-operational phases of all projects and facilities. The program goal is to minimize human exposures (occupational and public) to radiological and nonradiological hazards and conditions ALARA, commensurate with sound economics and operating practices. The program focuses on those activities with significant risk because of the presence of radiation, toxic substances, or hazardous conditions.

The WHC ALARA program is established by WHC-CM-1-3, MRP 5.37, and is described in WHC-IP-1043, WHC OCcupational ALARA Program. The WHC policy on radiation protection is described in WHC-CM-1-3 and HSRCM-1.

Responsibility for ensuring implementation of ALARA practices and principles is assigned to the WHC ALARA Program Office within the Safety Function. An ALARA committee is responsible for coordinating administration of company-wide activities and facility teams are established to implement ALARA practices and principles on an operational leve1. ALARA surveillances are conducted periodically by the Radiological Engineering and the measures are implemented in day to day activities. 
WHC-SD-WM-ISB-003, REV 1

3.2.3.2 Operational Considerations. A number of administrative controls are in place ensuring safety during maintenance activities. In particular, WHC-CM-1-10, WKS-6, provides for pre-job planning, a job hazards analysis, and the dual function of providing a responsible review of the work scope and zone, as well as heightening operator awareness of personal safety.

Operations and maintenance activities within the 340 Facility will be governed by technical procedures that incorporate ALARA and safety concerns. Maintenance activities are covered by preventive maintenance procedures.

In addition to safety guidance provided in operation and maintenance procedures, activities that involve radiological exposure must be performed in compliance with the protective measures identified in HSRCM-1. Entry into, and the work performed in any radiological area, is governed by the provisions of a radiological work permit (RWP) issued for that specific job or area. Radiological Control issues RWPs with the review and concurrence signature of Facility Operations management. The RWP must be followed by any person involved in the scope of operations described in the permit and only work specified in the RWP may be performed.

3.2.3.3 Area Radiation and Airborne Radioactivity Monitoring Instrumentation. Portable monitoring equipment may be used in support of the Radiation Protection Program developed for the 340 Facility operation to detect, record, and disseminate results of radiation and contamination surveys conducted in and around the facility. Monitoring may be performed before operations or maintenance activities involving surface contaminated areas.

Air sampling will be performed as required by the particular operations being conducted according to the criteria in HSRCM-1.

3.2.3.4 Radiological Control Program. This section provides information on the WHC Radiological Control Program organization, procedures, equipment, instrumentation, and facilities.

3.2.3.4.1 Radiological Control Organizations. Radiological safety functions are part of the Emergency, Safety, and Quality Services organization that has the overall responsibility for the radiation protection program. The Radiological Control group and the Nuclear Safety group have been delegated principal responsibility for support and overview of the radiation protection and ALARA programs.

Radiological Control is responsible for the following:

- Day-to-day operational support

- Auditing and monitoring compliance with DOE Orders, Washington Administrative Codes, standards, and other pertinent requirements

- Maintaining a trained staff and equipment capable of responding to incidents involving control and containment of radioactive materials

- Maintaining a radiological control support service that provides the radiological measurements, surveys, and dosimetry program necessary to ensure radiological safety 


\section{WHC-SD-WM-ISB-003, REV 1}

- Administering a comprehensive program that ensures that ALARA practices and principles are applied to the control of radiological hazards

- Providing expert advice to assist all WHC organizations in effectively meeting their radiation protection program responsibilities.

Nuclear Safety performs an independent oversight role. Either this organization or the Facility Evaluation Board is responsible for conducting annual safety appraisals of each WHC nuclear facility to ensure compliance with DOE Order 5482.1B, Environmenta7, Safety and Health Appraisal Program. Examples of activities covered by this organization include readiness reviews, design reviews, audits and appraisals, facility inspections, and operational surveillance assessments.

HPTs are trained and certified in accordance with 10 CFR 835 , occupational Radiation Protection, Subpart $J$, and are responsible for the dayto-day field implementation of the radiation protection program.

3.2.3.4.2 Equipment, Instrumentation, and Facilities. The following sections provide information on the various radiological control-related equipment, instrumentation, and facilities available to support the radiation protection program for the 340 Facility. The design, installation, operation, and calibration of radiological control instrumentation will be in accordance with WHC-SD-GN-DGS-30011, Radiological Design Guide, HSRCM-1, and WHC-IP-0718, Health Physics Procedures Manual (WHC 1991).

Air-Sampling Instruments - Stationary air-sampling instrumentation are in place in the 340 Building stack, the 340-B Loadout Facility stack, the decon stack and the vault and valve pits. Radiological Control may use portable air samplers. Gooseneck and high-volume grab samplers are used to provide longand short-term sampling of areas that have the potential to exceed $10 \%$ of a DAC during certain job evolutions.

Personnel Survey Instruments - Semiportable rate meters and PCM-1Bs for monitoring personnel are available at the 340 Facility. Both scintillation and Geiger-Mueller detectors are available for use by 340 Facility personnel.

3.2.3.4.3 Procedures. WHC has compiled a number of documents that describe requirements and procedures relative to radiological and environmental protection. A brief overview of relevant documents and summaries of various radiological protection procedures applicable to 340 Facility activities are provided below.

- WHC-CM-4-14, Applied Radiological Controls, provides methods, routine practices, controls, exposure guides, supporting data, and other information developed to assist radiological control personnel in establishing and maintaining a uniform and sound radiation control program.

- WHC-CM-7-5, Environmental Compliance Manual, provides detailed standards for controlling the release of radioactive and nonradioactive materials to air, water, and land, environmental 
WHC-SD-WM-ISB-003, REV 1

surveillance criteria, and effluent sampling and monitoring program requirements.

Radiological Control surveys - The methods, frequencies, and procedures for conducting radiation surveys are determined based on the characteristics of materials handled (i.e., form, element, isotope) and the radiological condition and type of operations conducted (i.e., dose rate, contamination leve1, or airborne potential).

Contamination Control - Bases and methods to control contamination are discussed in HSRCM-1. Actions to be taken if defined limits of contamination control are exceeded address personnel contamination and subsequent decontamination and documentation, along with control of equipment and surfaces that exhibit contamination. The basic policy is to preclude contamination through facility design by including mechanical constraints such as air filtration and temporary maintenance enclosures.

Safety Training - Safety training will be provided to all employees who work at the 340 Facility. In addition to radiation protection training, the WHC Safety Training Program consists of courses in general safety awareness, nuclear safety, hazardous materials, and waste. Responsibility for providing this training is assigned to the Safety Training section of the Technical Training Organization. WHC-CM-2-15, Training Administration Manual, describes procedures for course development and maintenance, scheduling, instructor certification, training delivery, student evaluation, and maintenance of training records.

The Safety Training Program includes a multi-tiered radiation protection training program that provides a level of training commensurate with an individual's classification as a radiation worker/nonradiation worker, as well as the individual's specific work assignment. Requirements for radiation protection training are stated in HSRCM-1 and are consistent with the requirements stated in DOE N 441.1 and 10 CFR 835.

Personnel Exposure Monitoring - WHC dosimetry program establishes requirements for measuring and recording personnel exposure. This program is described in Part 1 of the HSRCM-1. A summary of these requirements is provided in this subsection.

WHC requires that all employees, visitors, and vendors be issued and use an assigned record dosimeter at all times, when in radiological areas within a facility. These dosimeters provide an official measurement of an individual's radiation exposure. All record dosimeters used at WHC are accredited by the DOE Laboratory Accreditation Program. In addition to the Hanford Standard multi-purpose dosimeters, radiation workers may be required to wear supplemental dosimetry to monitor highly-localized doses. These devices may include finger rings, pencils, electronic dosimeters, two-chip dosimeters, wrist dosimeters, or special beta-photon dosimeters.

Exposure to internally deposited radionuclides is assessed by in vitro (excreta analysis) or in vivo (whole-body or chest-count) bioassay measurements. A baseline bioassay determination of internal radionuclides is performed for employees, visitors, and vendors as a prerequisite to any work assignment that involves the potential for internal deposition of 
radioactive material. Based on a review of the radionuclides and activity levels involved, the WHC Dosimetry Program determines the appropriate type of surveillance and establishes a routine internal exposure surveillance schedule.

As determined by Nuclear Safety, based on WHC-CM-4-29 and 340 CSER criteria, there is no need for criticality detection in the 340 Facility areas. However, nuclear accident dosimeters will be required to be posted at the 340 Facility regardless of criticality detection requirements for the 340 Facility, as other operations in the 300 Area will have sufficient fissile and fissionable material to require criticality detection systems and a criticality in those areas could affect personnel at the 340 Facility.

Occupational Radiation Exposure Records System - HSRCM-1 describes a system that maintains complete, accurate, and private personnel exposure data. The data include whole-body dose (neutron, beta, and gamma), extremity-dose (beta and gamma to fingers), and internal depositions. Hanford Site employees will have whole-body doses measured at a frequency dependent upon their work assignments as specified under Part 1 of the HSRCM-1.

Airborne Radioactivity Controls - Detailed methods and procedures for evaluating and controlling airborne radioactivity are discussed in WHC-SD-GNDGS-30011. Radiological Control may employ portable instrumentation to evaluate airborne radioactivity concentrations. Alpha, beta, and gammaemitters in air samples, as well as plutonium, noble gases, and iodine may be measured. Samples will be analyzed routinely, and the results may be reported to the Radiological Control, Facility Operations, Radiological Engineering, and ALARA organizations.

Airborne radioactivity concentrations will be controlled by using the design requirements stated in WHC-SD-GN-DGS-30011. Respiratory protection equipment may be required under special circumstances, as described in HSRCM1 .

\subsection{SUMMARY}

The 340 Facility RLWS and solid waste operations, with the controls outlined in this document, pose an acceptable risk to both the onsite and offsite individual. These operations maintain a radionuclide and chemical inventory without reliance on Safety Class or Safety Significant airconfinement barriers to reduce the amount of release to the onsite and offsite individual.

In accordance with DOE-STD-1027-92, the 340 Facility has been determined to be a Hazard Category 3 Facility. The credible accident scenarios, with a frequency greater than $10^{-6}$ per year, are an RLWS spray leak while pumping from the 340 Vault Tanks to the railroad tanker and a solid waste fire in 340-B West Building. Interim operational safety requirements have been developed to assure that the facility is maintained as a Hazard Category 3. Controlling the radioactive and hazardous material inventories ensures that potential onsite and offsite accident consequences are within the risk-acceptance guidelines. 


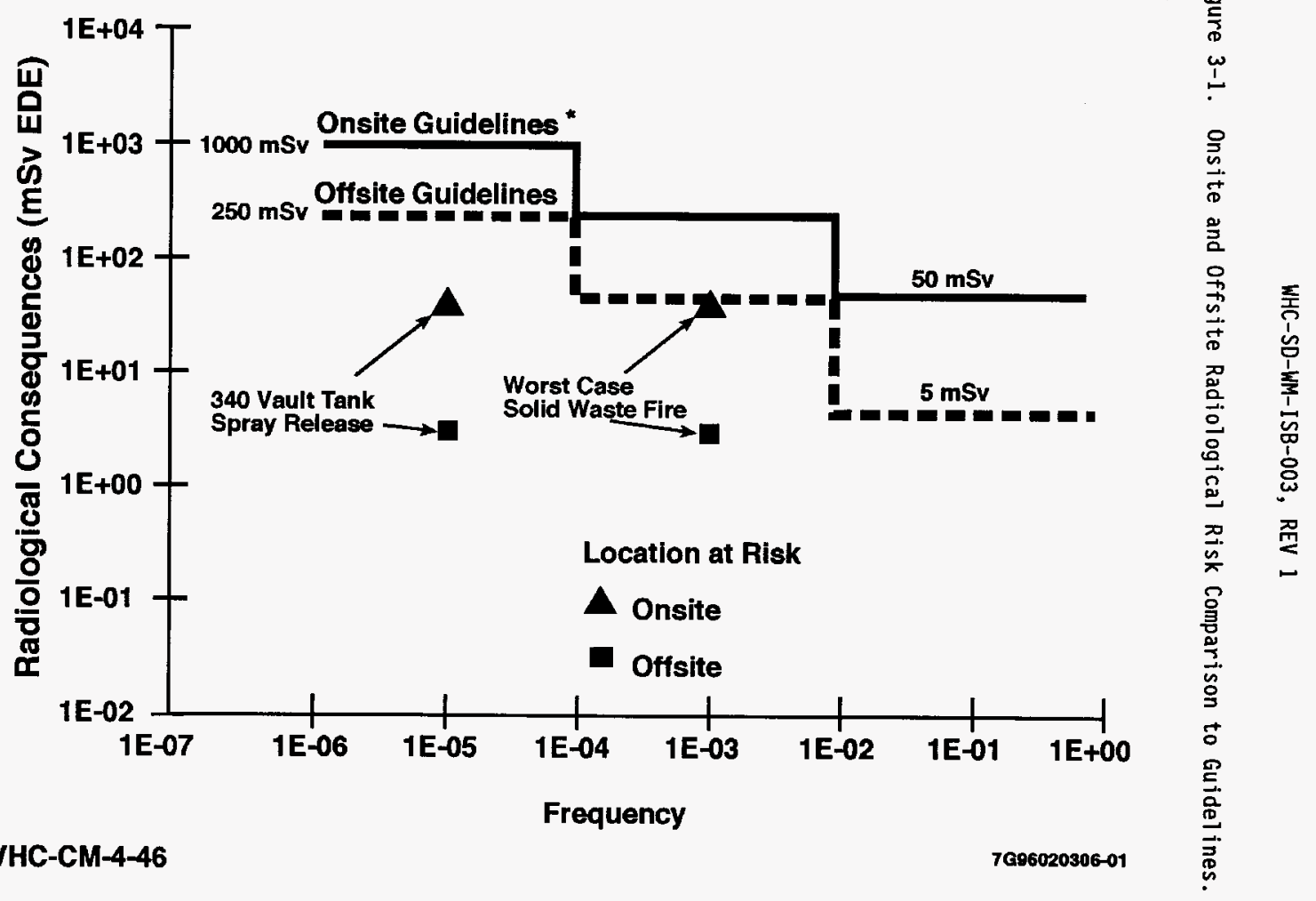


Table 3-1. 340 Vault Tank Hazard Category Calculations. ${ }^{1}$

\begin{tabular}{|c|c|c|c|c|c|}
\hline Isotope 2 & $\begin{array}{c}\text { Facility } \\
\text { inventofy } \\
(\mathrm{Ci} / \mathrm{L})^{3}\end{array}$ & $\begin{array}{c}\mathrm{Ci} / \operatorname{tank} \\
57 \mathrm{~kL} \\
(15,000 \mathrm{gal})\end{array}$ & $\underset{\text { (Ci) }}{\text { Category } 2 \text { To }}$ & $\begin{array}{l}\text { Modified } \\
\text { Category } 2 \text { TQ m } \\
\text { (Ci })^{4}\end{array}$ & $\begin{array}{l}\mathrm{Ci} / \mathrm{TQ}_{\mathrm{m}} \\
\text { (Ci }^{\mathrm{m}}\end{array}$ \\
\hline Beta/gamma & 6.90 E-01 & $3.93 E+04$ & $2.20 \mathrm{E}+04$ & $2.47 E+06$ & $1.59 \mathrm{E}-02$ \\
\hline \multirow[t]{2}{*}{ Alpha } & $1.16 E-03$ & $6.61 E+01$ & $5.60 \mathrm{E}+01$ & $6.18 E+03$ & 1.07 E-02 \\
\hline & & & Sum of ratios & Total & $2.66 E-02$ \\
\hline
\end{tabular}

${ }_{2}^{1}$ Based on the bounding source term in Table 2-3 and 9 the spray-release accident

2 For a worst-case inventory beta/ganma is taken as $90 \mathrm{Sr}$ and alpha is taken as $239 \mathrm{Pu}$.

3 simplified inventory based on total $\mathrm{Ci} / \mathrm{L}$ inventory for beta/garma and alpha emitters.

4 The Category 2 threshold quantities were modified as shown in Chapter 3.0

TO = threshold quantities.

$\mathrm{TQ}_{\mathrm{m}}=$ threshold quantities modified.

Table 3-2. Hazard Categorization of 340 B Building Solid Radioactive Waste.

\begin{tabular}{|c|c|c|c|}
\hline Isotope & $\begin{array}{c}\text { Worst-case inventory } \\
\text { of radioactive solid } \\
\text { waste (Ci) }\end{array}$ & $\begin{array}{c}\text { Category 2 Ta } \\
\text { (Ci) }\end{array}$ & $\begin{array}{c}\text { Total Ci/Ta } \\
\text { (Ci) }\end{array}$ \\
\hline Beta/gamma & $10.00 \mathrm{E}+00$ & $2.20 \mathrm{E}+04$ & $4.55 \mathrm{E}-04$ \\
\hline Alpha & $1.50 \mathrm{E}+00$ & $5.60 \mathrm{E}+01$ & $2.68 \mathrm{E}-02$ \\
\hline & & Sum of ratios & $2.72 \mathrm{E}-02$ \\
\hline
\end{tabular}

NOTE: For a worst-case inventory beta/gamma is taken as ${ }^{90} \mathrm{Sr}$ and alpha is taken as ${ }^{239} \mathrm{Pu}$. TQ $=$ threshold quantities.

Table 3-3. Calculation of Plutonium Equivalent Curie/Liter. ${ }^{1}$

\begin{tabular}{|c|c|c|c|c|c|c|}
\hline I sotope & $(\mathrm{Ci} / \mathrm{L})$ & $\begin{array}{l}\text { Correction } \\
\text { factor }\end{array}$ & $\begin{array}{c}P E \\
([i j / L)\end{array}$ & $\begin{array}{c}\text { Specific } \\
\text { activity } \\
\text { (ci/g) }\end{array}$ & $(g / L)$ & $\begin{array}{c}\text { Fraction of } \\
\text { total }\end{array}$ \\
\hline $241_{A m}$ & 6.26 E- 04 & 1 & 6.262 E- 04 & $3.42 E+00$ & $2.08 E+01$ & 0.1134108 \\
\hline $240 \mathrm{Pu}$ & 7.85 E-05 & 1 & 7.85 E-05 & 2.27 E-01 & $3.93 E+01$ & 0.2143256 \\
\hline $239 \mathrm{Pu}$ & 5.81 E-05 & 1 & $5.81 E-05$ & $6.20 \mathrm{E}-02$ & $1.06 E+02$ & 0.5804136 \\
\hline $242_{P U}$ & 2.35 E-07 & $1 / 1.1$ & $2.13 \mathrm{E}-07$ & $3.93 \mathrm{E}-03$ & $6.78 \mathrm{E}+00$ & 0.0370055 \\
\hline $238 \mathrm{Pu}$ & 2.72 E-04 & $1 / 1.1$ & 2.47 E- 04 & $1.71 E+01$ & $1.81 E+00$ & 0.0098606 \\
\hline $243 / 244 \mathrm{Cm}$ & 1.67 E-06 & $1 / 1.9$ & 8.77 E-07 & $8.10 E+01$ & $2.34 E-03$ & 0.0000127 \\
\hline $241_{\mathrm{Pu}}$ & 7.48 E-03 & $1 / 52$ & 1.44 E-04 & $1.03 E+02$ & $8.24 E+00$ & 0.0449712 \\
\hline Total & & & $1.16 \mathrm{E}-03$ & & & 1.0 \\
\hline
\end{tabular}

Based on Bounding Source Term (Table 2- $t$ ) and Appendix C of HHC-EP-0063-4.

2HHC-EP-0063-4, Table C-2.

HHC-EP-0063-4, Table C-7. 
Table 3-4. 340 Waste Handling Facility Preliminary Hazard Analysis. (6 sheets)

\begin{tabular}{|c|c|c|c|c|c|c|}
\hline \multirow{2}{*}{$\begin{array}{l}\text { Hazard/ } \\
\text { energy source }\end{array}$} & \multirow{2}{*}{$\begin{array}{l}\text { Potential accident } \\
\text { and sequence }\end{array}$} & \multirow{2}{*}{$\begin{array}{l}\text { Target/potential } \\
\text { consequences }\end{array}$} & \multicolumn{2}{|c|}{ Mitigating features } & \multirow{2}{*}{$\begin{array}{c}\text { Annual } \\
\text { probability }\end{array}$} & \multirow{2}{*}{ Severity } \\
\hline & & & Engineered & Adninistrative & & \\
\hline \multicolumn{7}{|c|}{ 1. Chonistry } \\
\hline \multicolumn{7}{|l|}{ A. Fire } \\
\hline 1. Range & None. & None. & $\begin{array}{l}\text { Area around buildings is } \\
\text { paved and/or graveled. }\end{array}$ & $\cdots$ & Incredible & IV \\
\hline \multicolumn{7}{|l|}{ 2. Building } \\
\hline 2a. 340 & $\begin{array}{l}\text { Fire could start in } \\
\text { office area. }\end{array}$ & $\begin{array}{l}\text { Fire and smoke damage, } \\
\text { personnel injury. }\end{array}$ & $\begin{array}{l}\text { Fire detection and } \\
\text { suppression system. }\end{array}$ & $\cdots$ & Unlikely & III \\
\hline 2b. 340 Decontanination & $\begin{array}{l}\text { Fire could start in or } \\
\text { spread to stored dry } \\
\text { waste. }\end{array}$ & $\begin{array}{l}\text { Radiological/ } \\
\text { Ioxicological release } \\
\text { could occur locally, } \\
\text { onsite ond of fsite. }\end{array}$ & $\begin{array}{l}\text { Fire detection and } \\
\text { suppression system. }\end{array}$ & $-\cdot$ & Unlikely & 111 \\
\hline 2c. 340 Control Room & $\begin{array}{l}\text { Fire could start in } \\
\text { wiring. }\end{array}$ & $\begin{array}{l}\text { Radiological/ } \\
\text { Toxicological } \\
\text { contamination could occur } \\
\text { locally. }\end{array}$ & $\begin{array}{l}\text { Fire detection and } \\
\text { suppression system. }\end{array}$ & $-\cdot$ & Unlikely & III \\
\hline 2d. $340-A$ & $\begin{array}{l}\text { Electrical fire could } \\
\text { occur. }\end{array}$ & None. & $\begin{array}{l}\text { Metal building, metal } \\
\text { tanks, and piping. - }\end{array}$ & $\begin{array}{l}\text { Ho flammable or } \\
\text { combust ible material } \\
\text { stored in building. }\end{array}$ & $\begin{array}{l}\text { Extremely } \\
\text { Unlifkely }\end{array}$ & III \\
\hline $\begin{array}{l}\text { 2e. 340-B East Railroad } \\
\text { Car Receiving }\end{array}$ & $\begin{array}{l}\text { Fire could start in } \\
\text { wiring. }\end{array}$ & $\begin{array}{l}\text { Radiological/ } \\
\text { Toxicological } \\
\text { contamination could oceur } \\
\text { locally. }\end{array}$ & $\begin{array}{l}\text { Metal building, metal } \\
\text { tanks, and piping. } \\
\text { Lighting and pumps only } \\
\text { power source. Fire } \\
\text { detection system. }\end{array}$ & $\begin{array}{l}\text { No flammable or } \\
\text { conbust ible material } \\
\text { stored in building. }\end{array}$ & $\begin{array}{l}\text { Extremely } \\
\text { unlikely }\end{array}$ & 111 \\
\hline $\begin{array}{l}\text { 2f. } 340-8 \text { West Dry Waste } \\
\text { Storage }\end{array}$ & $\begin{array}{l}\text { Fire could start in } \\
\text { stored waste. }\end{array}$ & $\begin{array}{l}\text { Radiological/ } \\
\text { Toxicological release } \\
\text { could occur locally, } \\
\text { onsite and offsite. }\end{array}$ & Fire Detection system. & -- & Unlikely & III \\
\hline \multicolumn{7}{|l|}{ 3. Liquid Petroleum Gas } \\
\hline $\begin{array}{l}\text { 3a. Fork lift or JLG } \\
\text { manl ift LPG tank }\end{array}$ & $\begin{array}{l}\text { Tank damage causes } \\
\text { leak. Result ing fire } \\
\text { impacts stored waste. }\end{array}$ & $\begin{array}{l}\text { Radiological/ } \\
\text { Toxicological release } \\
\text { could occur locally, } \\
\text { onsite and offsite. }\end{array}$ & $\begin{array}{l}\text { Design of fork lift and } \\
\text { JLG protects tank from } \\
\text { damage. Fire detection } \\
\text { systems }\end{array}$ & $\begin{array}{l}\text { Training of operators } \\
\text { in proper handl ing } \\
\text { techniques. }\end{array}$ & Anticipated & 111 \\
\hline $\begin{array}{l}\text { 3b. LPG tank near } 340 \\
\text { bldg. for auxiliary } \\
\text { heater }\end{array}$ & $\begin{array}{l}\text { Damage to LPG tank } \\
\text { causes leak, resulting } \\
\text { fire inpacts stored } \\
\text { waste. }\end{array}$ & $\begin{array}{l}\text { Radiological/ } \\
\text { Toxicological release } \\
\text { could occur locally. } \\
\text { onsite and of fsite }\end{array}$ & $\begin{array}{l}\text { Design of tank storage } \\
\text { cage protects tank. Fire } \\
\text { suppression system in } 340 \text {. }\end{array}$ & $\begin{array}{l}\text { Flamnable material not } \\
\text { stored or permitted } \\
\text { near LPG tanks. }\end{array}$ & Anticipated & 111 \\
\hline
\end{tabular}


Table 3-4. 340 Waste Handling Facility Preliminary Hazard Analysis. (6 sheets)

\begin{tabular}{|c|c|c|c|c|c|c|}
\hline \multirow{2}{*}{$\begin{array}{l}\text { Hazard/ } \\
\text { energy source }\end{array}$} & \multirow{2}{*}{$\begin{array}{l}\text { Potential accident } \\
\text { and sequence }\end{array}$} & \multirow{2}{*}{$\begin{array}{l}\text { Target/potential } \\
\text { consequences }\end{array}$} & \multicolumn{2}{|c|}{ Mitigating features } & \multirow{2}{*}{$\begin{array}{c}\text { Annual } \\
\text { probability }\end{array}$} & \multirow{2}{*}{ Severity } \\
\hline & & & Engineered & Administrative & & \\
\hline \multicolumn{7}{|c|}{ H. Chenistry (continued) } \\
\hline 3c. Any LPG tank. & $\begin{array}{l}\text { External fire } \\
\text { superheats tank } \\
\text { resulting in BLEVE. }\end{array}$ & $\begin{array}{l}\text { Radiological/ } \\
\text { Toxicological release } \\
\text { could occur locally, } \\
\text { onsite and offsite. }\end{array}$ & $\begin{array}{l}\text { (see A.3a \& b) Also, LPG } \\
\text { tanks have DOT mandated } \\
\text { pressure rel ief valves. }\end{array}$ & $\begin{array}{l}\text { Absence of fuel source } \\
\text { for heating tank. }\end{array}$ & Incredible & 11 \\
\hline \multicolumn{7}{|l|}{ B. Corrosion } \\
\hline \multicolumn{7}{|c|}{ 1. Corrosion fails drum/container } \\
\hline 1a. Dry Waste & $\begin{array}{l}\text { Dry waste released to } \\
\text { air. }\end{array}$ & $\begin{array}{l}\text { Radiological/ } \\
\text { Toxicological } \\
\text { contanination could occur } \\
\text { locally. }\end{array}$ & -- & $\begin{array}{l}\text { No long-term storage of } \\
\text { waste drums. }\end{array}$ & $\begin{array}{l}\text { Extremely } \\
\text { unl ikely }\end{array}$ & IV \\
\hline 1b. Liquid waste drums & Spill occurs. & $\begin{array}{l}\text { Radiological/ } \\
\text { Toxicological } \\
\text { contemination could occur } \\
\text { locally. }\end{array}$ & $\begin{array}{l}\text { Area has gravel around } \\
\text { building that reduces } \\
\text { evaporation. }\end{array}$ & $\begin{array}{l}\text { Incoming liquid dumped } \\
\text { into } 340 \text { vault Tanks in } \\
340 \text { decontamination } \\
\text { sump. }\end{array}$ & Unlikely & III \\
\hline \multicolumn{7}{|c|}{ 2. Corrosion fails tanks or piping } \\
\hline 2a. 340 Vault Tanks & $\begin{array}{l}\text { Corrosion in tank or } \\
\text { piping allows release. }\end{array}$ & $\begin{array}{l}\text { Release to ground could } \\
\text { occur. }\end{array}$ & $\begin{array}{l}\text { Tanks and most piping } \\
\text { under ground. Pipes and } \\
\text { tank double encased. Tank } \\
\text { vault is concrete. Leak } \\
\text { detection system. }\end{array}$ & $-\cdot$ & Untikely & III \\
\hline 2b. 340-A Tanks & $\begin{array}{l}\text { Corrosion in tank or } \\
\text { piping all lows release. }\end{array}$ & $\begin{array}{l}\text { Release to ground could } \\
\text { occur. }\end{array}$ & $\begin{array}{l}\text { Botton of tanks and most } \\
\text { piping underground. Pipes } \\
\text { double encased. Concrete } \\
\text { base and drains designed } \\
\text { to divert leaks to the } \\
340 \text { Vault tanks. Leak } \\
\text { detection system. }\end{array}$ & $\cdots$ & Unlikely & III \\
\hline \multicolumn{7}{|c|}{ 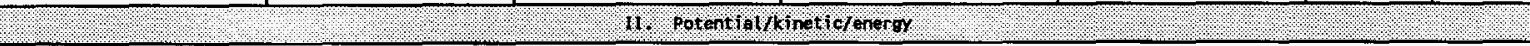 } \\
\hline \multicolumn{7}{|l|}{ A. Equipment } \\
\hline $\begin{array}{l}\text { 1. Heavy equipment } \\
\text { impacts drums/ } \\
\text { containers }\end{array}$ & $\begin{array}{l}\text { Drums or boxes } \\
\text { ruptured. }\end{array}$ & $\begin{array}{l}\text { Radiological/ } \\
\text { Toxicological } \\
\text { contamination could occur } \\
\text { localty. }\end{array}$ & $\cdots$ & None used in area. & $\begin{array}{l}\text { Extremely } \\
\text { Unt ikely }\end{array}$ & 111 \\
\hline $\begin{array}{l}\text { 2. Sharp/hard equipment } \\
\text { impacts drums/ } \\
\text { containers }\end{array}$ & $\begin{array}{l}\text { Drums or boxes } \\
\text { ruptured. }\end{array}$ & $\begin{array}{l}\text { Radiological/ } \\
\text { Toxicological } \\
\text { contamination could occur } \\
\text { locally. }\end{array}$ & $\cdots$ & $\begin{array}{l}\text { Only cert ified, } \\
\text { exper ienced, operators, } \\
\text { are allowed in } \\
\text { facilities. }\end{array}$ & Unl ikely & 111 \\
\hline
\end{tabular}


Table 3-4. 340 Waste Handling Facility Preliminary Hazard Analysis. (6 sheets)

\begin{tabular}{|c|c|c|c|c|c|c|}
\hline \multirow{2}{*}{$\begin{array}{l}\text { Hazard/ } \\
\text { energy source }\end{array}$} & \multirow{2}{*}{$\begin{array}{l}\text { Potent ial accident } \\
\text { and sequence }\end{array}$} & \multirow{2}{*}{$\begin{array}{l}\text { Target/potential } \\
\text { consequences }\end{array}$} & \multicolumn{2}{|c|}{ Mitigating features } & \multirow{2}{*}{$\begin{array}{c}\text { Annual } \\
\text { probability }\end{array}$} & \multirow{2}{*}{ Severity } \\
\hline & & & Engineered & Adninistrative & & \\
\hline \multicolumn{7}{|c|}{ 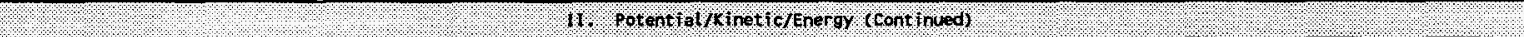 } \\
\hline 3. Drum/container dropped & Container splits open. & $\begin{array}{l}\text { Radiological/ } \\
\text { Toxicological } \\
\text { contamination could occur } \\
\text { locally. }\end{array}$ & $\begin{array}{l}\text { Orums lined with ten mil } \\
\text { nylon reinforced plastic. }\end{array}$ & $\begin{array}{l}\text { Stack height limited. } \\
\text { Drums can take } 3 \text { m drop } \\
\text { without fail ing. }\end{array}$ & $\begin{array}{l}\text { Extremely } \\
\text { Unlikely }\end{array}$ & III \\
\hline $\begin{array}{l}\text { 4. Liquid waste drum } \\
\text { dropped or damaged }\end{array}$ & Liquid spill to ground. & $\begin{array}{l}\text { Ground contamination } \\
\text { could occur. }\end{array}$ & $\begin{array}{l}\text { Ground around building } \\
\text { covered with gravel. }\end{array}$ & - & Untikely & 111 \\
\hline $\begin{array}{l}\text { 5. Pipe or pipe } \\
\text { connection fails while } \\
\text { pumping liquid waste } \\
\text { to tankcar }\end{array}$ & $\begin{array}{l}\text { Spray release could } \\
\text { occur. }\end{array}$ & $\begin{array}{l}\text { Radiological/ } \\
\text { Ioxicological release } \\
\text { could occur locally, } \\
\text { onsite and offsite. }\end{array}$ & $\begin{array}{l}\text { KVAC system operating } \\
\text { dur ing pumpout - radiation } \\
\text { alarms. }\end{array}$ & $\begin{array}{l}\text { Piping inspected prior } \\
\text { to connection. Leak } \\
\text { check at start of } \\
\text { pumping. Periodic } \\
\text { inspections for leaks. }\end{array}$ & $\begin{array}{l}\text { Extremely } \\
\text { unl ikely }\end{array}$ & 111 \\
\hline $\begin{array}{l}\text { 6. Ventilation } \\
\text { systen, fails } \\
\text { to maintain } \\
\text { a vacum in the } \\
\text { vault/tanks. }\end{array}$ & $\begin{array}{l}\text { Vault/tank pressurizes } \\
\text { above atmospheric } \\
\text { pressure. }\end{array}$ & $\begin{array}{l}\text { Radiological/ } \\
\text { Toxicological } \\
\text { contamination could occur } \\
\text { locally. }\end{array}$ & $\begin{array}{l}\text { Ground around building } \\
\text { covered with gravel. }\end{array}$ & $\begin{array}{l}\text { Procedures provide } \\
\text { recovery actions for } \\
\text { operations. }\end{array}$ & Untikely & 111 \\
\hline $\begin{array}{l}\text { 7. Ventilation } \\
\text { duct insulation } \\
\text { deteriorates. }\end{array}$ & $\begin{array}{l}\text { Internal ice buildup } \\
\text { during freezing } \\
\text { weather, vacum not } \\
\text { maintained. }\end{array}$ & $\begin{array}{l}\text { Radiological/ } \\
\text { Toxicological } \\
\text { contamination could occur } \\
\text { locally. }\end{array}$ & $\begin{array}{l}\text { Ground around building } \\
\text { covered with gravel: }\end{array}$ & $\begin{array}{l}\text { Periodic inspection and } \\
\text { maintenance or replace } \\
\text { worn insulation }\end{array}$ & Unl ikely & 111 \\
\hline $\begin{array}{l}\text { C. Hel icopter/or } \\
\text { plane crash }\end{array}$ & $\begin{array}{l}\text { Crash into facility } \\
\text { occurs. }\end{array}$ & $\begin{array}{l}\text { Radiological/ } \\
\text { Toxicological release } \\
\text { could occur locally, } \\
\text { onsite and of fsite. }\end{array}$ & -. & $\begin{array}{l}\text { Flights over facility } \\
\text { are rare. }\end{array}$ & $\begin{array}{l}\text { Extremely } \\
\text { unl ikely }\end{array}$ & 11 \\
\hline D. Transport Vehicle & $\begin{array}{l}\text { Waste drums dropped } \\
\text { while loading or } \\
\text { unloading. }\end{array}$ & $\begin{array}{l}\text { Radiological/ } \\
\text { Toxicological } \\
\text { contamination could occur } \\
\text { locally. }\end{array}$ & -- & $\begin{array}{l}\text { Only certified, } \\
\text { experienced, operators, } \\
\text { are allowed in } \\
\text { facilities. Drums can } \\
\text { take } 3 \text { m drop without } \\
\text { failing. }\end{array}$ & Unlikely & 111 \\
\hline & & 111 Marura & oocurrences & & & ? \\
\hline A. Flood & $\begin{array}{l}\text { The probable maximum flo } \\
\text { level at the } 340 \text { Buildin }\end{array}$ & $\begin{array}{l}\text { od could produce a river el } \\
\text { g } 118 \mathrm{~m}(387 \mathrm{ft}) \text {. The floo }\end{array}$ & $\begin{array}{l}\text { levation of } 116 \mathrm{~m}(382 \mathrm{ft}) \text { at } \\
\text { or level of the } 340 \text { Vault is }\end{array}$ & $\begin{array}{l}\text { bove mst which is } 1.5 \mathrm{~m} \\
\text { at } 111 \mathrm{~m}(365 \mathrm{ft}) \text { above }\end{array}$ & $\begin{array}{l}f t \text { ) below g } \\
\text { sl. }\end{array}$ & ound \\
\hline 1. High water & $\begin{array}{l}\text { High river flood covers } \\
\text { area. }\end{array}$ & $\begin{array}{l}\text { Overflow of vault tanks } \\
\text { to river. }\end{array}$ & - & $\cdots$ & $\begin{array}{l}\text { Extremely } \\
\text { unl ikely }\end{array}$ & 111 \\
\hline $\begin{array}{l}\text { 2. Heavy rain (flash } \\
\text { flood) }\end{array}$ & $\begin{array}{l}\text { Heavy rain inundates } \\
\text { area. }\end{array}$ & $\begin{array}{l}\text { Overflow of vault tanks } \\
\text { to river. }\end{array}$ & -- & 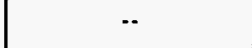 & Unlikely & 111 \\
\hline
\end{tabular}


Table 3-4. 340 Waste Handling Facility Preliminary Hazard Analysis. (6 sheets)

\begin{tabular}{|c|c|c|c|c|c|c|}
\hline \multirow{2}{*}{$\begin{array}{l}\text { Hazard/ } \\
\text { energy source }\end{array}$} & \multirow{2}{*}{$\begin{array}{l}\text { Potential accident } \\
\text { and sequence }\end{array}$} & \multirow{2}{*}{$\begin{array}{l}\text { Target/potential } \\
\text { consequences }\end{array}$} & \multicolumn{2}{|c|}{ Mitigating features } & \multirow{2}{*}{$\begin{array}{c}\text { Amnual } \\
\text { probabil lity }\end{array}$} & \multirow{2}{*}{ Severity } \\
\hline & & & Engineered & Administrative & & \\
\hline \multicolumn{7}{|c|}{ 1) Wotural occurrences (Gontinued) } \\
\hline B. Seismic event & \multicolumn{6}{|c|}{ Strong earthquake collapses buildings ruptures tanks } \\
\hline 1. 340 & Office area destroyed. & $\begin{array}{l}\text { Property damage and } \\
\text { personnel injury could } \\
\text { occur. }\end{array}$ & $-\cdot$ & -. & Unt ikely & IV \\
\hline 2. 340 Decontamination & $\begin{array}{l}\text { Sample and packaging } \\
\text { area destroyed. }\end{array}$ & $\begin{array}{l}\text { Minor release could } \\
\text { occur. }\end{array}$ & -- & $\cdots$ & Unlikely & 111 \\
\hline 3. 340 Control Room & $\begin{array}{l}\text { Instrument panel and } \\
\text { Controls destroyed. }\end{array}$ & $\begin{array}{l}\text { Minor release could } \\
\text { occur. }\end{array}$ & -- & $-\cdot$ & Unl ikety & 111 \\
\hline 4. 340-A & $\begin{array}{l}\text { Tanks ruptured } \\
\text { concrete base cracked. }\end{array}$ & $\begin{array}{l}\text { Ground release could } \\
\text { occur. }\end{array}$ & $\cdots$ & -- & Unt ikely & II I \\
\hline $\begin{array}{l}\text { 5a. } 340-\text { B rail road car } \\
\text { receiving } \\
\text { (empty) }\end{array}$ & $\begin{array}{l}\text { Loading plat form and } \\
\text { pumping equipment } \\
\text { damaged or destroyed. }\end{array}$ & $\begin{array}{l}\text { Minor radiological/ } \\
\text { toxicological release } \\
\text { could occur locally. }\end{array}$ & $-\cdot$ & $\cdots$ & Unl ikely & 111 \\
\hline $\begin{array}{l}\text { 5b. 340-B rail road } \\
\text { car receiving } \\
\text { (car in place) }\end{array}$ & $\begin{array}{l}\text { Loading plat form } \\
\text { and pumping } \\
\text { equipment damaged } \\
\text { or destroyed, } \\
\text { rai l road car } \\
\text { damaged. }\end{array}$ & $\begin{array}{l}\text { Radiological/ } \\
\text { toxicological } \\
\text { release could } \\
\text { occur locally, } \\
\text { ons ite and } \\
\text { of fsite. }\end{array}$ & -- & $\cdot \cdot$ & Incredible & 11 \\
\hline $\begin{array}{l}\text { 6. 340-B dry waste } \\
\text { storage }\end{array}$ & $\begin{array}{l}\text { Drums and boxes split } \\
\text { open. }\end{array}$ & $\begin{array}{l}\text { Radiological/ } \\
\text { toxicological release } \\
\text { could occur locally. } \\
\text { onsite and offsite. }\end{array}$ & $\because$ & -- & $\begin{array}{l}\text { Extremely } \\
\text { unlikely }\end{array}$ & 111 \\
\hline \multicolumn{7}{|l|}{ C. Wind } \\
\hline 1. Missile & $\begin{array}{l}\text { Wind blown missile } \\
\text { could penetrate } \\
\text { building. }\end{array}$ & $\begin{array}{l}\text { Property dangge and } \\
\text { personnel injury could } \\
\text { occur. Minor release } \\
\text { possible. }\end{array}$ & $-\cdot$ & $\begin{array}{l}\text { Area kept free of loose } \\
\text { materials and trash. }\end{array}$ & Unt ikely & III \\
\hline 2. Pressure & $\begin{array}{l}\text { Building could be } \\
\text { destroyed. }\end{array}$ & $\begin{array}{l}\text { Property damage and } \\
\text { personnel injury could } \\
\text { occur. Minor release } \\
\text { possible. }\end{array}$ & $\begin{array}{l}\text { UBC, 2one } 11 \text {, which } \\
\text { provides for a wind } \\
\text { loading of } 98 \text {. } \\
\mathrm{kg} / \mathrm{m}^{2}\left(20\left(\mathrm{~b} / \mathrm{ft}^{2}\right) 142 \mathrm{~km} / \mathrm{h}\right. \\
(88 \mathrm{~m} / \mathrm{hr})\end{array}$ & $\cdots$ & Unt ikely & III \\
\hline
\end{tabular}


Table 3-4. 340 Waste Handling Facility Preliminary Hazard Analysis. (6 sheets)

\begin{tabular}{|c|c|c|c|c|c|c|}
\hline \multirow{2}{*}{$\begin{array}{c}\text { Hazard/ } \\
\text { energy source }\end{array}$} & \multirow{2}{*}{$\begin{array}{l}\text { Potential accident } \\
\text { and sequence }\end{array}$} & \multirow{2}{*}{$\begin{array}{l}\text { Target/potential } \\
\text { consequences }\end{array}$} & \multicolumn{2}{|c|}{ Mitigating features } & \multirow{2}{*}{$\begin{array}{c}\text { Annual } \\
\text { probability }\end{array}$} & \multirow{2}{*}{ Severity } \\
\hline & & & Engineered & Administrat ive & & \\
\hline & & II) Matural occur & rences r continued) & & & $m$ \\
\hline \multicolumn{7}{|l|}{ D. Volcanic Activity } \\
\hline $\begin{array}{l}\text { 1. Ash buildup collapses } \\
\text { building. }\end{array}$ & $\begin{array}{l}\text { Building could be } \\
\text { destroyed. }\end{array}$ & $\begin{array}{l}\text { Property damage and } \\
\text { persomel injury could } \\
\text { occur. Minor release } \\
\text { possible. }\end{array}$ & -. & -- & Unlikely & 111 \\
\hline \multicolumn{7}{|l|}{ E. Lightening } \\
\hline $\begin{array}{l}\text { 1. Lightening strikes } \\
\text { building. }\end{array}$ & $\begin{array}{l}\text { Electrical shorts and } \\
\text { fire started. }\end{array}$ & $\begin{array}{l}\text { Radiological/ } \\
\text { toxicological release } \\
\text { could occur locally. } \\
\text { onsite and of fsite. }\end{array}$ & $\begin{array}{l}\text { All buildings on grounding } \\
\text { grid. }\end{array}$ & $-\cdot$ & $\begin{array}{l}\text { Extremely } \\
\text { unlikely }\end{array}$ & 111 \\
\hline \multicolumn{7}{|c|}{ 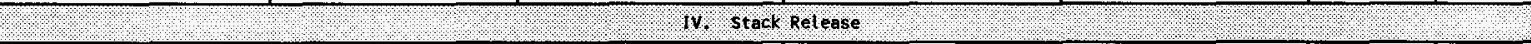 } \\
\hline A. HEPA filters & $\begin{array}{l}\text { Fire or HEPA filter } \\
\text { failure causes stack } \\
\text { release. }\end{array}$ & $\begin{array}{l}\text { Minor Radiological/ } \\
\text { toxicological release } \\
\text { could occur. }\end{array}$ & DP gauge across filters. & $\begin{array}{l}\text { Replacement on reaching } \\
\text { set DP limit. Nornal } \\
\text { stack release compl ies } \\
\text { wi th WHC-CH-7-5. }\end{array}$ & $\begin{array}{l}\text { Extremely } \\
\text { Unlikely }\end{array}$ & 111 \\
\hline B. Charcoal filters & $\begin{array}{l}131_{\text {I }} \text { release from } \\
340 \text { vault. }\end{array}$ & -. & $\begin{array}{l}\text { Charcoal filters. (not } \\
\text { actively maintained) }\end{array}$ & $\begin{array}{l}\text { Notification of } \\
349 \text { Facility prior to } \\
\text { I release to RLHS by } \\
\text { labs. }\end{array}$ & -- & -- \\
\hline \multicolumn{7}{|c|}{ 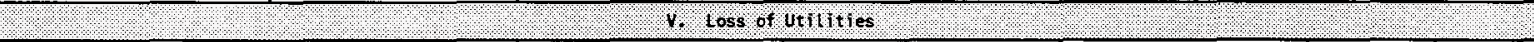 } \\
\hline A. Electrical & $\begin{array}{l}\text { Storm or accident cuts } \\
\text { off all electrical } \\
\text { power. }\end{array}$ & $\begin{array}{l}\text { Loss of stack flows and } \\
\text { monitoring indication } \\
\text { al arms and lights. }\end{array}$ & Emergency lighting. & $\begin{array}{l}\text { Suspension of all waste } \\
\text { handling operations. }\end{array}$ & Anticipated & IV \\
\hline B. Process water & $\begin{array}{l}\text { Lose of pump seal } \\
\text { water. }\end{array}$ & $\begin{array}{l}\text { Pump motor danaged by } \\
\text { overheating. }\end{array}$ & Puip shutdown interlock. & -. & Ant icipated & Iv \\
\hline \multicolumn{7}{|c|}{ 11. Rodiation } \\
\hline A. Contemination & Marked radiation zones. & $\begin{array}{l}\text { Persons working in zone } \\
\text { could become } \\
\text { contaminated. }\end{array}$ & $\begin{array}{l}\text { Zones marked and/or } \\
\text { isolated by rope fence. }\end{array}$ & $\begin{array}{l}\text { ALARA rules are in } \\
\text { effect. Personal } \\
\text { Protective Equipment } \\
\text { required. }\end{array}$ & Anticipated & III \\
\hline B. Exposure & $\begin{array}{l}\text { High-level radiation } \\
\text { inventory }\end{array}$ & $\begin{array}{l}\text { Radiation monitors, } \\
\text { concrete cover blocks. }\end{array}$ & $\cdots$ & .. & Anticipated & III \\
\hline c. Criticality & $\begin{array}{l}\text { Fissile materials are } \\
\text { present. }\end{array}$ & Criticality could occur. & -- & $\begin{array}{l}\text { Facil ity compl iance } \\
\text { wi th UHC-CM-4-29. }\end{array}$ & $\begin{array}{l}\text { Extremely } \\
\text { inlikely }\end{array}$ & II \\
\hline
\end{tabular}


Table 3-4. 340 Waste Handling Facility Preliminary Hazard Analysis. (6 sheets)

\begin{tabular}{|c|c|c|c|c|c|c|}
\hline \multirow{2}{*}{$\begin{array}{c}\text { Hazard/ } \\
\text { energy source }\end{array}$} & \multirow{2}{*}{$\begin{array}{l}\text { Potential accident } \\
\text { and sequence }\end{array}$} & \multirow{2}{*}{$\begin{array}{l}\text { Target/potential } \\
\text { consequences }\end{array}$} & \multicolumn{2}{|c|}{ Mitigating features } & \multirow{2}{*}{$\begin{array}{c}\text { Annual } \\
\text { probability }\end{array}$} & \multirow{2}{*}{ Severity } \\
\hline & & & Engineered & Administrative & & \\
\hline
\end{tabular}

ALARA = as Low as reasonably achievable.

BLEVE = boiling liquid expanding vapor explosion

DOT = Department of Iransportation

$D P=$ differential pressure.

FHA = Federal Housing Administration.

HEPA = high-efficiency particulate air (filter).

HVAC = heating, ventilation, and air conditioning.

LPG $=$ I iquid petroleum gas.

msl = mean sea level.
$U B C=$ Uni form Building code. 
Table 3-5. Probability Category Definition and Qualitative Accident Severity Levels.

\begin{tabular}{|c|c|c|c|c|}
\hline \multicolumn{3}{|c|}{ Probability category definition } & \multicolumn{2}{|c|}{ Qualitative accident severity levels } \\
\hline $\begin{array}{l}\text { Annual frequency } \\
\text { category } \\
\text { (AFC) }\end{array}$ & $\begin{array}{l}\text { Category } \\
\text { description }\end{array}$ & $\begin{array}{l}\text { Nominal range of } \\
\text { annual frequency }\end{array}$ & $\begin{array}{l}\text { Severity category } \\
\text { (SC) }\end{array}$ & $\begin{array}{l}\text { Consequences to the public, workers, or } \\
\text { environment }\end{array}$ \\
\hline $\begin{array}{l}\text { Anticipated } \\
\text { (A) }\end{array}$ & $\begin{array}{l}\text { An offnormal condition that individually may be } \\
\text { expected to occur once or more during plant } \\
\text { lifetime. }\end{array}$ & $10^{-2}$ to 1 & Category I & $\begin{array}{l}\text { May cause deaths onsite or loss of the } \\
\text { facility/operation, major injuries or } \\
\text { illnesses offsite, radiation exposure to } \\
\text { of fsite individuals to individuals in } \\
\text { excess of annual limits, or severe inpact } \\
\text { on the enviromment. }\end{array}$ \\
\hline $\begin{array}{l}\text { Unlikely } \\
(U)\end{array}$ & $\begin{array}{l}\text { Individually, condition is not expected to occur } \\
\text { during the plant lifetime, but collectively, } \\
\text { events in this category may occur several times. }\end{array}$ & $10^{-4}$ to $10^{-2}$ & Category 11 & $\begin{array}{l}\text { May cause severe injuries or severe } \\
\text { occupational illnesses onsite, exposure to } \\
\text { onsite individuals in excess of annual } \\
\text { limits, major damage to a facility } \\
\text { operation, minor illnesses or injury } \\
\text { offsite, exposure to of fsite individuals to } \\
\text { radiation below annual imits, or major } \\
\text { impact on the enviroment. }\end{array}$ \\
\hline $\begin{array}{l}\text { Extremely } \\
\text { unlikely } \\
\text { (EU) }\end{array}$ & $\begin{array}{l}\text { Extremely low-probability conditions that are } \\
\text { not expected during the plant lifetime, but that } \\
\text { represent extreme or limiting cases of faults } \\
\text { identif ied as possible. This category includes } \\
\text { design basis accidents. }\end{array}$ & $10^{-6}$ to $10^{-4}$ & Category III & $\begin{array}{l}\text { May cause minor injury or minor } \\
\text { occupational illness onsite, or exposure of } \\
\text { onsite individuals to radiation below } \\
\text { annual limits, negi igible impact of fsite, } \\
\text { or minor impact on the environment. }\end{array}$ \\
\hline $\begin{array}{l}\text { Incredible } \\
\text { (I) }\end{array}$ & $\begin{array}{l}\text { Accidents for wich no creditable scenario can } \\
\text { be identified. }\end{array}$ & $<10^{-6}$ & Cotegory IV & $\begin{array}{l}\text { Will not result in injury, occupational } \\
\text { illness, exposure onsite, or offsite, or } \\
\text { result in a significant impact to the } \\
\text { worker. }\end{array}$ \\
\hline
\end{tabular}


Table 3-6. Operating Hazards. (2 sheets)

\begin{tabular}{|c|c|c|c|c|c|c|c|c|c|c|c|}
\hline \multirow[b]{2}{*}{ Room location } & \multirow[b]{2}{*}{ Equipment } & \multirow{2}{*}{$\begin{array}{l}\text { Mazardous } \\
\text { material }\end{array}$} & \multicolumn{7}{|c|}{ Hazards } & \multirow[b]{2}{*}{ Mitigating features } & \multirow{2}{*}{$\begin{array}{l}\text { Administrative } \\
\text { controls }\end{array}$} \\
\hline & & & Fire & $\begin{array}{c}\text { Electric } \\
\text { shock }\end{array}$ & $\begin{array}{l}\text { Air } \\
\text { borne }\end{array}$ & Noise & $\begin{array}{l}\text { Surface } \\
\text { contan- } \\
\text { ination }\end{array}$ & $\begin{array}{c}\text { Skin } \\
\text { contam- } \\
\text { ination }\end{array}$ & $\begin{array}{l}\text { Whole } \\
\text { body } \\
\text { dose }\end{array}$ & & \\
\hline $\begin{array}{l}340 \text { Building } \\
\text { Vaut t }\end{array}$ & RLW vault tanks & RLW & -. & $x$ & $x$ & -- & $x$ & $x$ & $x$ & $\begin{array}{l}\text { Tanks below ground } \\
\text { level, Concrete walls } \\
\text { and.3 m } 12^{\prime \prime \prime} \text { thick } \\
\text { concrete shielded } \\
\text { cover blocks. Access } \\
\text { hatch, covered wi th } \\
\text { penthouse. }\end{array}$ & $\begin{array}{l}\text { Entry for maintenance } \\
\text { and inspection only. } \\
\text { PPE. }\end{array}$ \\
\hline $\begin{array}{l}340 \text { Building } \\
\text { Vault }\end{array}$ & RLW agitators & RLL & -. & $x$ & $x$ & $x$ & $x$ & $x$ & $x$ & $\begin{array}{l}\text { Access through hole in } \\
\text { cover block, covered } \\
\text { by penthouse. Pumps } \\
\text { control led from } \\
\text { control room. }\end{array}$ & $\begin{array}{l}\text { Entry for maintenance } \\
\text { and inspection only, } \\
\text { PPE. }\end{array}$ \\
\hline $\begin{array}{l}340 \text { Building } \\
\text { Vault }\end{array}$ & RLW pumps & RLH & $-\cdot$ & $x$ & $x$ & $x$ & $x$ & $x$ & $x$ & $\begin{array}{l}\text { Access through hole in } \\
\text { cover block, covered } \\
\text { by penthouse. Pumps } \\
\text { control led from } \\
\text { control room. }\end{array}$ & $\begin{array}{l}\text { Entry for maintenance } \\
\text { and inspection only, } \\
\text { PPE. }\end{array}$ \\
\hline $\begin{array}{l}340 \text { Building } \\
\text { Vault, valve } \\
\text { pit }\end{array}$ & $\begin{array}{l}\text { RLN valves and } \\
\text { piping }\end{array}$ & RLM & -- & -- & $x$ & -- & $x$ & $x$ & $x$ & \multirow{2}{*}{$\begin{array}{l}\text { Access hatch, covered } \\
\text { by penthouse. }\end{array}$} & \multirow{2}{*}{$\begin{array}{l}\text { Entry for maintenance } \\
\text { and inspection only, } \\
\text { PPE. }\end{array}$} \\
\hline $\begin{array}{l}340 \text { Building } \\
\text { Vault, valve } \\
\text { pit }\end{array}$ & $\begin{array}{l}\text { Sample/backup } \\
\text { pump }\end{array}$ & RLM & $\cdot \cdot$ & $x$ & $x$ & $x$ & $x$ & $x$ & $x$ & & \\
\hline 340 Buil lding & $\begin{array}{l}\text { MaOH tank and } \\
\text { pumps }\end{array}$ & -- & -- & .. & - & $\ldots$ & -. & - & -- & Renoved. & -. \\
\hline $\begin{array}{l}340 \text { Building } \\
\text { mechanical } \\
\text { room }\end{array}$ & $\begin{array}{l}\text { Air compressor, } \\
\text { vacum pump, } \\
\text { MCC }\end{array}$ & oil & $x$ & $x$ & -. & $x$ & -- & -- & -- & $\begin{array}{l}\text { Fire detection and } \\
\text { suppression system. }\end{array}$ & $\begin{array}{l}\text { Ear protection } \\
\text { required. }\end{array}$ \\
\hline $\begin{array}{l}340 \text { Building } \\
\text { decon room }\end{array}$ & $\begin{array}{l}\text { Decon chemicals } \\
\text { and equipment }\end{array}$ & $\begin{array}{l}\text { Contan- } \\
\text { ination, } \\
\text { toxic } \\
\text { chenicals }\end{array}$ & $x$ & $x$ & -. & -- & $x$ & $x$ & $x$ & $\begin{array}{l}\text { Steel grated trough } \\
\text { drains to sump } \\
\text { Fire detection and } \\
\text { suppression system. }\end{array}$ & PPE as needed. \\
\hline $\begin{array}{l}340 \text { Building } \\
\text { decon room }\end{array}$ & Sample hood & $\begin{array}{c}\text { RLW, } \\
\text { toxic } \\
\text { chericals }\end{array}$ & -- & $x$ & -. & -. & $x$ & $x$ & $x$ & $\begin{array}{l}\text { Steel grated trough } \\
\text { drains to sump. }\end{array}$ & PPE as needed. \\
\hline $\begin{array}{l}340 \text { Building } \\
\text { extension }\end{array}$ & $\begin{array}{l}\text { Sol id waste } \\
\text { packaging and } \\
\text { storage }\end{array}$ & $\begin{array}{l}\text { Solid } \\
\text { mixed } \\
\text { waste }\end{array}$ & $x$ & $x$ & -- & $x$ & -. & -- & $x$ & $\begin{array}{l}\text { Fire detection and } \\
\text { suppression system. }\end{array}$ & -- \\
\hline
\end{tabular}


Table 3-6. Operating Hazards. (2 sheets)

\begin{tabular}{|c|c|c|c|c|c|c|c|c|c|c|c|}
\hline \multirow[b]{2}{*}{ Room location } & \multirow[b]{2}{*}{ Equipment } & \multirow[b]{2}{*}{$\begin{array}{l}\text { Hazardous } \\
\text { material }\end{array}$} & \multicolumn{7}{|c|}{ Hazards } & \multirow[b]{2}{*}{ Mitigating features } & \multirow[b]{2}{*}{$\begin{array}{l}\text { Administrative } \\
\text { controls }\end{array}$} \\
\hline & & & Fire & $\begin{array}{l}\text { Electric } \\
\text { shock }\end{array}$ & $\begin{array}{c}\text { Air } \\
\text { borne }\end{array}$ & Noise & $\begin{array}{l}\text { Surface } \\
\text { contam- } \\
\text { ination }\end{array}$ & $\begin{array}{c}\text { Skin } \\
\text { contam- } \\
\text { ination }\end{array}$ & $\begin{array}{l}\text { Whole } \\
\text { body } \\
\text { dose }\end{array}$ & & \\
\hline $\begin{array}{l}340 \text { Building } \\
\text { control room }\end{array}$ & $\cdots$ & -. & $x$ & $x$ & -- & $\cdot-$ & -- & -- & .. & $\begin{array}{l}\text { Access through outside } \\
\text { door. } \\
\text { F i re detection and } \\
\text { suppression system. }\end{array}$ & -- \\
\hline $\begin{array}{l}340-A \\
\text { Building }\end{array}$ & $\begin{array}{l}\text { Storage tanks } \\
\text { and valves }\end{array}$ & RLW & -- & $x$ & $x$ & $\cdots$ & $x$ & $x$ & $x$ & $\begin{array}{l}\text { Bot tom of tanks below } \\
\text { ground. ory sump } \\
\text { drains to vault tanks. }\end{array}$ & $\begin{array}{l}\text { Access tightly } \\
\text { restricted, PPE. }\end{array}$ \\
\hline $\begin{array}{l}340-8 \\
\text { Building } \\
\text { raitroad car } \\
\text { receiving }\end{array}$ & Tankcar loading & RLW & -- & $x$ & $x$ & $x$ & $x$ & $x$ & $x$ & $\begin{array}{l}\text { Shield wall, loading } \\
\text { control led from } \\
\text { control room. }\end{array}$ & $\begin{array}{l}\text { Access restricted, } \\
\text { PPE. }\end{array}$ \\
\hline $\begin{array}{l}\text { 340-B } \\
\text { Building dry } \\
\text { waste storage }\end{array}$ & $\begin{array}{l}208 \perp \text { ( } 55-g a l) \\
\text { drums, and } \\
\text { boxes }\end{array}$ & $\begin{array}{l}\text { Solid } \\
\text { mixed } \\
\text { waste }\end{array}$ & $x$ & $x$ & $x$ & $\cdots$ & $x$ & $x$ & $x$ & $\begin{array}{l}\text { Shield wall separates } \\
\text { solid waste storage } \\
\text { area from tankcar } \\
\text { loadout. Fire } \\
\text { detection system. }\end{array}$ & $\cdot \cdot$ \\
\hline $\begin{array}{l}\text { mo-037 } \\
\text { trailer }\end{array}$ & Facility office & -- & $x$ & $x$ & -- & -. & -. & -. & -. & $\begin{array}{l}\text { Fire detection and } \\
\text { suppression system. }\end{array}$ & -- \\
\hline $\begin{array}{l}\text { Mo-741 } \\
\text { trailer }\end{array}$ & $\begin{array}{l}\text { HPT office and } \\
\text { survey station. }\end{array}$ & -- & $x$ & $x$ & .. & - & -- & -- & -- & $\begin{array}{l}\text { Fire detection and } \\
\text { suppression system. }\end{array}$ & -- \\
\hline
\end{tabular}

HPT = health physics technician.

ACC = motor control center.

PPE = personal protect ive equipment.

$R L W=$ radioactive liquid waste. 
Table 3-7. Maximum Individual Dose Due to an Aerosol Release of 1 Curie of Each Isotope From the 340 Facility. (2 sheets)

\begin{tabular}{|c|c|c|c|c|c|}
\hline Receptor & $\begin{array}{c}\text { Onsite } \\
100 \mathrm{~m} \text { north }\end{array}$ & $\begin{array}{c}\text { Offsite } \\
345 \text { m East }\end{array}$ & $\begin{array}{c}\text { Onsite } \\
100 \mathrm{~m} \text { north }\end{array}$ & $\begin{array}{l}\text { Offsite } \\
345 \text { m East }\end{array}$ & \\
\hline$x / 0$ & $4.21 \mathrm{E}-02$ & $3.77 \mathrm{E}-03$ & $4.21 \mathrm{E}-02$ & $3.77 \mathrm{E}-3$ & \\
\hline leotopo & \multicolumn{2}{|c|}{$\begin{array}{c}\text { Annusl Effoctive Dose } \\
\text { Equivalent }\end{array}$} & \multicolumn{2}{|c|}{ Moximum Organ } & Orgen \\
\hline $3^{3} H$ & $1.30 \mathrm{E}-03$ & $1.16 \mathrm{E}-04$ & $1.60 \mathrm{E}-03$ & 1.43 E-04 & Bone \\
\hline${ }^{14} \mathrm{C}$ & $2.90 \mathrm{E}-02$ & $2.60 \mathrm{E}-03$ & $3.70 \mathrm{E}-02$ & $3.31 \mathrm{E}-03$ & R. Marrow \\
\hline $22 \mathrm{Na}$ & 1.20 E-01 & $1.07 \mathrm{E}-02$ & $1.80 \mathrm{E}-01$ & $1.61 \mathrm{E}-02$ & Bone \\
\hline${ }^{54} \mathrm{Mn}$ & $9.60 \mathrm{E}-02$ & $6.60 \mathrm{E}-03$ & 3.50 E-01 & $3.13 \mathrm{E}-\mathrm{O} 2$ & Lung \\
\hline${ }^{57} \mathrm{Co}$ & $1.20 \mathrm{E}-01$ & 1.07 E-02 & 8.70 E-01 & 7.79 E-02 & Lung \\
\hline${ }^{59} \mathrm{Fo}$ & $1.80 \mathrm{E}-01$ & $1.61 \mathrm{E}-02$ & $7.30 \mathrm{E}-01$ & $6.54 \mathrm{E}-02$ & Lung \\
\hline${ }^{60} \mathrm{Co}$ & $2.80 E+\infty 0$ & $2.51 \mathrm{E}-01$ & $1.80 E+01$ & $1.61 \mathrm{E}+\infty$ & Lung \\
\hline${ }^{63} \mathrm{Ni}$ & 3.20 E-02 & $2.87 \mathrm{E} \cdot 03$ & $1.60 \mathrm{E} \cdot 01$ & $1.43 \mathrm{E}-02$ & Lung \\
\hline${ }^{65_{Z n}}$ & $2.60 \mathrm{E}-01$ & $2.33 \mathrm{E} \cdot \mathrm{O} 2$ & $1.10 E+\infty$ & $9.65 \mathrm{E}-\mathrm{O} 2$ & Lung \\
\hline${ }^{75} \mathrm{se}$ & $1.20 \mathrm{E}-01$ & $1.07 \mathrm{E}-02$ & $2.90 \mathrm{E}-01$ & $2.60 \mathrm{E}-02$ & Lung \\
\hline${ }^{79}$ se & $1.30 \mathrm{E}-01$ & $1.16 \mathrm{E}-02$ & 5.10 E-01 & $4.57 E-02$ & Lung \\
\hline${ }^{65} \mathrm{Sr}$ & 2.60 E-02 & $2.33 \mathrm{E}-03$ & 5.10 E-02 & $4.57 \mathrm{E}-03$ & Bono \\
\hline${ }^{90} \mathrm{Sr}$ & $2.80 \mathrm{E}+00$ & $2.51 \mathrm{E}-01$ & $3.40 E+01$ & $3.04 \mathrm{E}+\infty 0$ & Bone \\
\hline $90 Y$ & $1.20 \mathrm{E}-01$ & $1.07 \mathrm{E}-\mathrm{O} 2$ & $5.00 \mathrm{E} \cdot 01$ & $4.48 \mathrm{E}-02$ & Lung \\
\hline${ }^{93} \mathrm{Zr}$ & $1.10 E+\infty$ & $9.85 \mathrm{E}-02$ & $2.60 E+01$ & $2.51 \mathrm{E}+\infty$ & Bone \\
\hline${ }^{95} \mathrm{Zr}$ & 2.20 E-01 & $1.97 \mathrm{E}-02$ & $1.20 E+C 0$ & $1.07 \mathrm{E}-01$ & Bone \\
\hline${ }^{95} \mathrm{Nb}$ & 8.70 E-O2 & 7.79 E-03 & $4.40 \mathrm{E}-01$ & $3.94 \mathrm{E}-02$ & Lung \\
\hline${ }^{99} \mathrm{Tc}$ & $1.30 \mathrm{E}-01$ & $1.16 \mathrm{E}-02$ & $8.60 \mathrm{E}-01$ & $7.88 \mathrm{E}-02$ & Lung \\
\hline${ }^{10 \bar{E}_{\mathrm{Ru}}}$ & $6.60 \mathrm{E}+00$ & 5.91 E-01 & $6.30 \mathrm{E}+01$ & $4.75 E+\infty$ & Lung \\
\hline${ }^{109} \mathrm{Cd}$ & $1.60 E+\infty 0$ & 1.43 E-01 & $2.10 E+01$ & $1.88 E+\infty 0$ & Kidney \\
\hline${ }^{125} \mathrm{sb}$ & $1.80 \mathrm{E}-01$ & $1.61 \mathrm{E}-02$ & $1.20 E+\infty$ & $1.07 \mathrm{E}-01$ & Lung \\
\hline 131 & $4.30 \mathrm{E}-01$ & 3.85 E-02 & $1.40 \mathrm{E}+01$ & $1.25 E+\infty$ & Thyroid \\
\hline${ }^{134} \mathrm{C}$ & $6.10 \mathrm{E}-01$ & 5.46 E-02 & 7.30 E-01 & 6.54 E-02 & Small int \\
\hline${ }^{137} \mathrm{Cs}$ & $4.30 \mathrm{E}-01$ & 3.85 E-O2 & 4.70 E-01 & $4.21 \mathrm{E}-02$ & Small int \\
\hline${ }^{144} \mathrm{Co}_{0}$ & $5.20 E+00$ & 4.66 E-01 & $4.10 E+01$ & $3.67 \mathrm{E}+\infty$ & Lung \\
\hline${ }^{15 !} \mathrm{sm}$ & $4.20 \mathrm{E}-01$ & 3.76 E-02 & $7.10 \mathrm{E}+00$ & $6.36 \mathrm{E}-01$ & Bone \\
\hline${ }^{152} \overline{E u}$ & $2.90 E+00$ & 2.60 E-01 & $1.80 \mathrm{E}+01$ & $1.61 \mathrm{E}+\infty$ & Liver \\
\hline${ }^{154} \mathrm{Eu}$ & $3.90 E+00$ & 3.49 E-01 & $2.70 \mathrm{E}+01$ & $2.42 \mathrm{E}+\infty$ & Bone \\
\hline${ }^{155} \mathrm{Eu}$ & $6.70 \mathrm{E}-01$ & $5.10 \mathrm{E}-02$ & $7.60 E+00$ & $6.81 \mathrm{E}-01$ & Bone \\
\hline${ }^{182} \mathrm{Ta}$ & $6.20 \mathrm{E}-01$ & $5.55 \mathrm{E}-02$ & $4.30 \mathrm{E}+00$ & $3.85 \mathrm{E}-01$ & Lung \\
\hline 234 & $1.90 E+03$ & $1.70 E+02$ & $1.50 \mathrm{E}+04$ & $1.34 \mathrm{E}+03$ & Lung \\
\hline $235 u$ & $1.70 E+03$ & $1.52 \mathrm{E}+02$ & $1.40 E+04$ & $1.25 E+03$ & Lung \\
\hline${ }^{236} U$ & $1.80 E+03$ & $1.61 \mathrm{E}+02$ & $1.50 \mathrm{E}+04$ & $1.34 E+03$ & Lung \\
\hline $238 \mathrm{U}$ & $1.70 E+03$ & $1.52 \mathrm{E}+02$ & $1.40 E+04$ & $1.25 \mathrm{E}+03$ & Lung \\
\hline${ }^{238} \mathrm{Pu}$ & $4.00 E+03$ & $3.58 E+02$ & $3.80 E+04$ & $3.40 E+03$ & Bone \\
\hline
\end{tabular}


Table 3-7. Maximum Individual Dose Due to an Aerosol Release of 1 Curie of Each Isotope From the 340 Facility. (2 sheets)

\begin{tabular}{|c|c|c|c|c|c|}
\hline Recoptor & $\begin{array}{l}\text { Oneite } \\
100 \mathrm{~m} \text { north }\end{array}$ & $\begin{array}{l}\text { Offsito } \\
345 \text { m East }\end{array}$ & $\begin{array}{l}\text { Onsito } \\
100 \mathrm{~m} \text { north }\end{array}$ & $\begin{array}{c}\text { Offaite } \\
345 \mathrm{~m} \text { East }\end{array}$ & \\
\hline$x / 0$ & 4.21 E-02 & $3.77 \mathrm{E}-03$ & $4.21 \mathrm{E}-02$ & $3.77 \mathrm{E}-3$ & \\
\hline Isotope & \multicolumn{2}{|c|}{$\begin{array}{c}\text { Annual Effoctive Dose } \\
\text { Equivalent }\end{array}$} & \multicolumn{2}{|c|}{ Maximum Organ } & Organ \\
\hline${ }^{200} \mathrm{Pu}$ & $4.30 E+03$ & $3.85 E+02$ & $4.40 E+04$ & $3.94 E+03$ & Bone \\
\hline${ }^{240} \mathrm{Pu}$ & $4.20 E+03$ & $3.76 E+02$ & $4.40 \mathrm{E}+0.4$ & $3.94 E+03$ & Bone \\
\hline $241_{P u}$ & $6.90 E+01$ & $6.18 \mathrm{E}+\infty 0$ & $9.30 E+02$ & $8.33 E+01$ & Bone \\
\hline 242Pu & $4.10 E+03$ & $3.67 E+02$ & $4.00 E+04$ & $3.58 E+03$ & Bone \\
\hline${ }^{241} \mathrm{Am}$ & $6.20 E+03$ & $5.55 E+02$ & $1.10 E+05$ & $9.85 E+03$ & Bone \\
\hline${ }^{243} \mathrm{~cm}$ & $4.30 E+03$ & $3.86 E+02$ & $7.60 E+04$ & $6.81 E+03$ & Bone \\
\hline${ }^{244} \mathrm{Cm}$ & $3.50 E+03$ & $3.13 E+02$ & $6.10 E+04$ & $6.46 E+03$ & Bone \\
\hline
\end{tabular}

Table 3-8. Dose Consequences for a Spray-Release Accident. (a)

\begin{tabular}{|c|c|c|c|c|c|c|}
\hline Isotope $^{(\mathrm{b})}$ & $\mathrm{Ci} / \mathrm{L}$ & $\mathrm{Ci}$ released & rem/Ci Onsite & $\begin{array}{c}\text { rem/Ci } \\
\text { Offsite }\end{array}$ & $\begin{array}{c}\text { rem } \\
\text { Onsite }\end{array}$ & rem Offsite \\
\hline Beta/Gamma & $6.90 \mathrm{E}-01$ & $3.53 \mathrm{E}-01$ & $3.90 \mathrm{E}+00$ & $3.30 \mathrm{E}-01$ & $1.38 \mathrm{E}+00$ & $1.16 \mathrm{E}-01$ \\
\hline Alpha & $1.16 \mathrm{E}-03$ & $5.93 \mathrm{E}-04$ & $4.30 \mathrm{E}+03$ & $3.60 \mathrm{E}+02$ & $2.55 \mathrm{E}+00$ & $2.13 \mathrm{E}-01$ \\
\hline Total & -- & -- & -- & -- & $3.92 \mathrm{E}+00$ & $3.30 \mathrm{E}-01$ \\
\hline
\end{tabular}

(a)For a 5.11 E-4 L release while pumping from the 340 Vault tank to a railroad tankcar.

(b) $F 959$ worst case inventory the Beta/Gamm distribution was modeled as ${ }^{154}$ Eu and the Alpha was modeled as $239^{\circ} \mathrm{Pu}$.

Table 3-9. Dose Consequences When Burning the 340-B West Building Solid Wastes.

\begin{tabular}{|l|c|c|c|c|c|c|}
\hline Isotope & $\begin{array}{c}\text { Total } \\
\text { curies }\end{array}$ & $\begin{array}{c}\text { Curies } \\
\text { released }\end{array}$ & $\begin{array}{c}\text { Onsite } \\
\text { (ren/Ci) }\end{array}$ & $\begin{array}{c}\text { Offsite } \\
\text { (ren/Ci) }\end{array}$ & $\begin{array}{c}\text { Onsite } \\
\text { (rem) }\end{array}$ & $\begin{array}{c}\text { Offsite } \\
\text { (rem) }\end{array}$ \\
\hline Bets/gamms & $10.00 \mathrm{E}+00$ & $5.00 \mathrm{E}-03$ & $3.90 \mathrm{E}+00$ & $3.3 \mathrm{E}-01$ & $1.95 \mathrm{E}-02$ & $1.65 \mathrm{E}-03$ \\
\hline Alpha & $1.50 \mathrm{E}+00$ & $7.50 \mathrm{E}-04$ & $4.30 \mathrm{E}+03$ & $3.60 \mathrm{E}+02$ & $3.23 \mathrm{E}+00$ & $2.70 \mathrm{E}-01$ \\
\hline Total & & & & & $3.24 \mathrm{E}+00$ & $2.72 \mathrm{E}-01$ \\
\hline
\end{tabular}

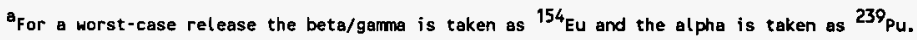


Table 3-10. 340 Facility Safety Enhancement Systems.

\begin{tabular}{|c|c|c|}
\hline Component/system & Provisions & $\begin{array}{l}\text { Codes, standards, } \\
\text { and regulations }\end{array}$ \\
\hline \multicolumn{3}{|c|}{ stock semplet $10 n i l o r h s$ systen } \\
\hline 340 Building Stack & Continuous isokinetic sempler/no monitor. & ANSI N $13.1-1982$ \\
\hline 340 Vault Stack & $\begin{array}{l}\text { Cont inuous isokinetic sampler. Cont inwous monitoring of beta } \\
\text { and alphe particulates. }\end{array}$ & ANSI N 13.1-1982 \\
\hline Personnel Protection & $\begin{array}{l}\text { Process Radiation Detectors are installed in the } 340 \text { valve } \\
\text { Box } 9 \text { and in } 340-A \text {. These detectors are installed to give } \\
\text { indication of changes in activity level or movement of } \\
\text { radioactive liquids but also provide indication of high } \\
\text { radiation levels. }\end{array}$ & $\begin{array}{l}\text { DOE N } 441.1 \text {, and } \\
10 \text { CFR } 835\end{array}$ \\
\hline \multicolumn{3}{|c|}{ recl 1 ty conf inement containment systens } \\
\hline 340 Building stack & Two-stage HEPA filters, one fan (no backup). & \multirow{3}{*}{ HHC-CM-7-5 } \\
\hline 340 Vault stack & Two stages HEPA filters, denister, two fans: & \\
\hline 340-B Building Stack & One stage NEPA filters, one fan (no backup). & \\
\hline \multicolumn{3}{|c|}{ froprotecton systems } \\
\hline 340 Building & $\begin{array}{l}\text { Smoke detectors, temperature detectors, and sprinkler } \\
\text { systems-alarms locally and at the Hanford Fire Department } \\
\text { Central Dispstch Center. }\end{array}$ & \multirow[t]{2}{*}{ DOE Order $5480.7 \mathrm{~A}$} \\
\hline 340-B Building & $\begin{array}{l}\text { Smoke detectors - alarms locally and at the Hanford Fire } \\
\text { Department Central Oispatch Center. }\end{array}$ & \\
\hline
\end{tabular}




\section{WHC-SD-WM-ISB-003, REV 1}

This page intentionally without substantive content. 
WHC-SD-WM-ISB-003, REV 1

\subsection{CONFIGURATION CONTROLS SYSTEM}

The configuration control system for WHC is administered using procedures, standards and practices of WHC-CM-6-1, standard Engineering Practices. This manual governs all engineering, development and project tasks that result in a documented design and/or deliverable engineered product. These engineering practices provide a graded approach to the principles of configuration management and design control to ensure that engineering tasks and deliverable engineered products produced from these tasks are identified, authorized, verified, changed, and documented by a controlled methodology, that is consistent with the importance of the activities to safety, health, environment, continuity of operations, and value. Drawing controls, operating, and maintenance procedure controls, USQ, procedures and quality assurance procedures all provide assurance that functional and physical characteristics of the facility are maintained within the safety basis and that the ISB-003 is maintained current.

\subsection{DRANING CONTROL}

Engineering drawings initiated and approved by or for WHC are prepared in accordance with WHC-CM-6-1, EP-1.3, and WHC-IP-1026, Engineering Practices Guidelines, (WHC 1994a). This manual implements DOE Richland Operations Office (RL) Order 6430.1C, Hanford P7ant Standards, Design Criteria, SDC-1.3, "Preparation and Control of Engineering and Fabrication Drawings." A11 released engineering drawings are stored in designated storage facilities. Before release, a designated reviewer ensures the drawing is in accordance with the above manuals. The approval process for drawings uses the engineering data transmittal form for recording approval signatures (Engineering Practice procedure EP-1.6, WHC-CM-6-1). Revision of approved drawings follow the procedures specified in EP-2.2, "Engineering Document Change Contro1." Approval of revised drawings use the engineering data transmittal form, as noted above.

\subsection{PROCEDURE CONTROL}

WHC maintains a policy that all operations are to be conducted in accordance with written procedures. The requirement for complying with procedures is stated in Appendix A of WHC-CM-1-3, MRP 4.16, "Standards of Conduct." Compliance with the detailed instructions in procedures is essential for safe and reliable operation. The procedures (maintenance and operating) will comply with the applicable requirements of DOE Orders 4330.4B and 5480.19 , as stated in the requirements of WHC-CM-3-5, Document Control and Records Management Manual, Section 12.0, "Document Control," and Section 12.5, "Working Leve1 Procedure Control," and WHC-CM-4-2, Section 6.0, "Document Control."

These procedures and policies apply to all facilities and organizations that require the use of procedures for guidance and control of day-to-day activities, including the 340 Facility. Each facility is responsible for controlling, maintaining, and modifying the procedures to achieve the highest standards of safety, efficiency, and excellence in conduct of operations. 
WHC-SD-WM-ISB-003, REV 1

The procedures are maintained current in procedure books that are readily available for the users. Outdated procedures are removed and replaced as procedure revisions are approved and issued. Management accepts the responsibility of assuring that personnel using the procedures are trained and qualified.

\subsection{UNREVIEWED SAFETY QUESTIONS}

The USQ process complies with DOE Order 5480.21 and is administered by WHC using WHC-CM-1-5, Section 7.3, "Identifying and Resolving Unreviewed Safety Questions." The safety evaluation process makes use of the methodology and risk-acceptance guidelines contained in WHC-CM-4-46. This process allows WHC to make physical and procedural changes and conduct tests and experiments without prior DOE approval, as long as the changes do not affect the safety basis of the facility or result in a change to a technical safety requirement or IOSR. Conversely, the USQ evaluation process starts when changes to the operations and facility, a discovery of new conditions, or a discovery of an error in the safety analysis affects the safety basis of the facility or results in changes to a technical safety requirement or IOSR.

The USQ process also ensures that discoveries representing conditions outside the safety basis or technical safety requirements are identified. This is to ensure that actions are taken to modify the conditions or to redefine the safety basis.

The USQ process applies to activities at all WHC-managed facilities (existing and new). The 340 Facility complies with the USQ process by evaluating proposed changes, tests, and experiments. If a USQ exists, a USQ safety evaluation will be performed and documented on the change. 340 Facility occurrences will be evaluated to determine if a discovery (potential USQ) might exist. If a discovery exists, the 340 Facility manager will be notified and actions will be taken to determine if the facility is in a safe (or safest) mode or state, based on the potential inadequacy or reduction in technical safety requirement margin. The appropriate RL Line manager will be notified when an occurrence is determined to be a discovery.

\subsection{QUALITY ASSURANCE}

The quality assurance program established by WHC for the design, construction, modification, and operation of the 340 Facility is consistent with the requirements of 10 CFR 830.120 Quality Assurance. The quality assurance program is administered using the requirements and instructions within WHC-CM-4-2 and WHC-SP-1131. It is WHC policy that the Quality Assurance program will be executed to provide adequate confidence that designs, construction, testing, and operations meet regulatory requirements and that the 340 Facility operations will be safe and efficient. The management plans and procedural controls necessary for safe operation and control will be documented, as required by DOE Orders. The Quality Assurance program applies to all activities that could effect safety and reliability at the 340 Facility. The Quality Assurance program also includes quality control. Included in the quality control are the Quality Assurance activities that provide control of the quality of the material, structure, component, or 
system to predetermined requirements (including ISB requirements). Quality control provides verification that functional and physical characteristics of the facility are maintained within the safety envelope and that the ISB is maintained current. 


\section{WHC-SD-WM-ISB-003, REV 1}

This page intentionally without substantive content. 
WHC-SD-WM-ISB-003, REV 1

\subsection{REFERENCES}

\subsection{DOCUMENTS}

Altschuler, S.J. 1995, CSER 94-012: Criticality Safety Evaluation Report for 340 Building, WHC-SD-SQA-CSA-20379, Rev. 0, Westinghouse Hanford Co., Richland, Washington, Feb. 15, 1995. [superseded by Rev. 1 (see Miller)]

ANSI, 1982, Guide to Sampling Airborne Radioactive Materials in Nuclear Facilities, ANSI N13.1-1982, American National Standards Institute, New York, New York.

Berneski, L.D., 1992, 340 Facility Equipment List, WHC-SD-WM-SEL-016, Rev. 1, Westinghouse Hanford Company, Richland, Washington. [superseded by Rev. 2 (see Vogel), and this ISB]

Berneski, L.D., 1994, Safety Assessment Document for the 340 Facility, SD-WM-TM-001, Rev. 0-A, Westinghouse Hanford Company, Richland, Washington. [superseded by this ISB]

Berneski, L.D., 1995, Hanford 300 Area Retention Process Sewer - Inventory at Risk Calculations and Safety Analysis, WHC-SD-WM-SAD-027, Rev. 0, Westinghouse Hanford Company, Richland, Washington.

Mercado, J. E., 1993, Safety Analysis Report for Packaging, Railroad Liquid Waste Tank Cars, SD-RE-SAP-013, Rev. 6, Westinghouse Hanford Company, Richland, Washington.

Miller, E.M., 1996, CSER 94-012: Criticality Safety Eva7uation Report for 340 Building, WHC-SD-SQA-CSA-20379, Rev. 1, Westinghouse Hanford Co., Richland, Washington, Feb. 15, 1996.

Mishima, J., L. C. Schwendiman, and J. E. Ayers, 1978, Increment of Analysis: An Estimate of Airborne Release of Plutonium From Babcock and Wilcox Plan As A Result of Severe Wind, PNL-2812, Pacific Northwest Laboratory, Richland, Washington.

Napier, B. A. et al., 1988, GENII--The Hanford Environmental Radiation Dosimetry System Software System, Version 1.485, PNL-6845, Pacific Northwest Laboratory, Richland, Washington.

Roberts, L.W., 1995, 340 Complex Fire Hazard Analysis, WHC-SD-WM-FHA-011, Rev. 0 , prepared by Hughes Associates, Inc., Columbia, Maryland, for Westinghouse Hanford Company, Richland, Washington.

Vogel, H.R., 1994, 340 Facility Equipment List, WHC-SD-WM-SEL-016, Rev. 2, Westinghouse Hanford Company, Richland, Washington, April 25, 1994. [superseded by ISB]

WHC, 1989, Operating Limits for the 340 Facility, OSR-SW-152-00003, Rev. A-0, West inghouse Hanford Company, Richland, Washington. [superseded by ISB] 
WHC-SD-WM-ISB-003, REV 1

WHC, 1990, Operating Specification Document for the 340 Waste Handling Facility, OSD-SW-153-0001, Westinghouse Hanford Company, Richland, Washington. [superseded by ISB]

WHC, 1991, Health Physics Procedures Manual, WHC-IP-0718, Westinghouse Hanford Company, Richland, Washington.

WHC, 1992, A Model for Estimating the Release Rate of Aerosol Droplets From Pressurized Liquid Leaks, WHC-SD-GN-TI-30003, Westinghouse Hanford Company, Richland, Washington

WHC, 1993, Hanford Site Solid Waste Acceptance Criteria, WHC-EP-0063, West inghouse Hanford Company, Richland, Washington.

WHC, 1994a, Engineering Practices Guidelines, WHC-IP-1026, Westinghouse Hanford Company, Richland, Washington.

WHC, 1994b, 300 Area Effluent Facilities Administrative Manual, WHC-IP-1000, Westinghouse Hanford Company, Richland, Washington.

WHC, 1995a, Building Emergency Plan, 340 Waste Management Facility, WHC-IP-0263-340, Rev. 4, Westinghouse Hanford Company, Richland, Washington.

WHC, 1995b, Waste Specification System, WHC-EP-0846, K.L. Kirkpatrick and B.L. Oswald, Westinghouse Hanford Co., Richland, WA, January 1995.

WHC, 1996a, 340 Facility Waste Tank System Integrity Assessment Report, WHCSD-WM-ER-546, Rev. 0, E.J. Walter, Westinghouse Hanford Company, Richl and, Washington.

WHC, 1996b, 340 Deactivation P7an, WHC-SD-LEF-SSP-001, Rev. O, L.D. Berneski and R.T. Stordeur, Westinghouse Hanford Company, Richl and, Washington.

UBC, 1991, Uniform Building Code, International Conference of Building officials, Whittier, California.

\subsection{U.S. FEDERAL CODES AND DEPARTMENT OF ENERGY ORDERS/GUIDELINES}

10 CFR 830.120, Quality Assurance, Code of Federal Regulations, as amended.

10 CFR 835 , Occupational Radiation Protection, Code of Federal Regulations, as amended.

D0E-HDBK-3010-94, Airborne Release Fractions/Rates and Respirable Fractions for Nonreactor Nuclear Facilities, U.S. Department of Energy, Washington, D.C.

DOE-STD-1027-92, Hazard Categorization and Accident Analysis Techniques for Compliance with DOE Order 5480.23, Nuclear Safety Analysis Reports, U. S. Department of Energy, Washington, D.C. 
DOE-STD-3011-94, Guidance for Preparation of DOE 5480.22 (TSR) and DOE 5480.23 (SAR) Implementation Plans, U. S. Department of Energy, Washington, D.C.

DOE Order 4330.4B, Maintenance Management Program, U. S. Department of Energy, Washington, D.C.

DOE Order 5480.7A, Fire Protection, U.S. Department of Energy, Washington, D.C.

DOE Order 5480.10, Radiological Control, U.S. Department of Energy, Washington, D.C.

DOE Order 5480.19, Conduct of Operations Requirements for DOE Facilities, U.S. Department of Energy, Washington, D.C.

DOE Order 5480.21, Unreviewed Safety Questions, U.S. Department of Energy, Washington, D.C.

DOE Order 5480.23, Nuclear Safety Analysis Reports, U.S. Department of Energy, Washington, D.C.

DOE Order, 5480.24, Nuclear Criticality Safety, U.S. Department of Energy, Washington, D.C.

DOE Order, 5481.1B, Safety Analysis and Review System, U.S. Department of Energy, Washington, D.C.

DOE Order, 5482.1B, Environmental, Safety, and Health Appraisal Program, U.S. Department of Energy, Washington, D.C.

DOE Order 5820.2A, Radioactive Waste Management, U.S. Department of Energy, Washington, D.C.

RL Order 6430.1C, Hanford P7ant Standards, U.S. Department of Energy, Richland Operations office, Richland, Washington.

\subsection{WESTINGHOUSE HANFORD COMPANY CONTROLLED MANUALS}

HSRCM-1, Hanford Site Radiological Control Manual, Hanford Contractors Richland, Washington.

WHC-CM-1, Company Policies and Charters, Westinghouse Hanford Company, Richland, Washington.

WHC-CM-1-3, Management Requirements and Procedures, Westinghouse Hanford Company, Richland, Washington.

WHC-CM-1-10, Safety Manual, Westinghouse Hanford Company, Richland, Washington.

WHC-CM-1-11, Industrial Hygiene Manual, Westinghouse Hanford Company, Richl and, Washington. 
WHC-CM-2-14, Hazardous Material Packaging and Shipping, Westinghouse Hanford Company, Richland, Washington.

WHC-CM-3-5, Document Control and Records Management, Westinghouse Hanford Company, Richl and, Washington.

WHC-CM-4-1, Fire Protection Program, Westinghouse Hanford Company, Richland, Washington.

WHC-CM-4-2, Quality Assurance, Westinghouse Hanford Company, Richland, Washington.

WHC-CM-4-29, Nuclear Criticality Safety, Westinghouse Hanford Company, Richland, Washington.

WHC-CM-4-33, Security, Westinghouse Hanford Company, Richland, Washington.

WHC-CM-4-41, Fire Protection Program, Westinghouse Hanford Company, Richland, Washington.

WHC-CM-4-43, Emergency Management Procedures, Westinghouse Hanford Company, Richland, Washington.

WHC-CM-4-46, Nonreactor Facility Safety Analysis, Westinghouse Hanford Company, Richland, Washington.

WHC-CM-6-1, Standard Engineering Practices, Westinghouse Hanford Company, Richland, Washington.

WHC-CM-7-5, Environmental Compliance, Westinghouse Hanford Company, Richland, Washington.

WHC-SP-1131, Rev. 1, WHC Quality Assurance Program and Implementation Plan, Westinghouse Hanford Company, Richland, Washington. 
WHC-SD-WM-ISB-003 REV 1

\section{APPENDIX A}

CONDUCT OF OPERATIONS CONPARATIVE EVALUATION 
WHC-SD-WM-ISB-003 REV 1

This page intentionally without substantive content. 
Table A-1. Identification of DOE Orders, WHC Control Manuals, and 340 Facility Implementing Documentation. ( 8 sheets)

\begin{tabular}{|c|c|c|c|}
\hline $\begin{array}{l}\text { Institutional } \\
\text { control or safety } \\
\text { requirement }\end{array}$ & $\begin{array}{l}\text { Federal Codes and DOE } \\
\text { Orders and titles }\end{array}$ & $\begin{array}{c}\text { Applicable WHC controlled } \\
\text { manuals }\end{array}$ & $\begin{array}{c}340 \text { Facility implementing } \\
\text { document }(\mathrm{s})\end{array}$ \\
\hline $\begin{array}{l}\text { Radiation } \\
\text { Protection }\end{array}$ & $\begin{array}{l}10 \text { CFR Part } 835 \\
\text { Occupational Radiation } \\
\text { Protection } \\
5400.5, \text { Radiation } \\
\text { Protection of the Public } \\
\text { and the Environment } \\
5480.4, \text { Environmental } \\
\text { Protection, Safety, and } \\
\text { Health Protection } \\
\text { Standards } \\
\text { N } 441.1, \text { Radiological } \\
\text { Protection for DoE } \\
\text { Activities }\end{array}$ & $\begin{array}{l}\text { WHC-CM-1-3, Management } \\
\text { Requirements and Procedures } \\
\text { HSRCM-1, Rev. 2, Hanford } \\
\text { Site Radiological Control } \\
\text { Manual } \\
\text { WHC-CM-7-5, Environmental } \\
\text { Compliance } \\
\text { WHC-IP-1043, WHC } \\
\text { OcCupational A7 ara Program }\end{array}$ & $\begin{array}{l}\text { WHC-IP-1000, } 300 \text { Area Liquid } \\
\text { Effluent Facilities } \\
\text { Administration, Section 1.11 } \\
\text { "Radiological Protection Program" } \\
\text { will address radiation protection } \\
\text { within the } 340 \text { Facility. } \\
\text { Personnel shall be aware of their } \\
\text { own exposure levels and take } \\
\text { appropriate action to minimize } \\
\text { exposures (such as time, distance } \\
\text { and shielding). } \\
\text { WHC-IP-1000, } 300 \text { Area Liquid } \\
\text { Effluent Facilities } \\
\text { Administration, Section } 2.2 \text {, } \\
\text { "Shift Routines and Operating } \\
\text { Practices" requires that all } \\
\text { operators verify important } \\
\text { parameters using a checklist, } \\
\text { especially those pertaining to } \\
\text { safety, to ensure continuity of } \\
\text { operations in a safe and } \\
\text { effective manner. }\end{array}$ \\
\hline ALARA & $\begin{array}{l}10 \text { CFR Part } 835 \\
\text { Occupational Radiation } \\
\text { Protection }\end{array}$ & $\begin{array}{l}\text { HSRCM-1, Hanford Site } \\
\text { Radiological Control Manual } \\
\text { WHC-IP-1043, WHC } \\
\text { Occupational Alara Program }\end{array}$ & $\begin{array}{l}\text { WHC-IP-1000, } 300 \text { Area Liquid } \\
\text { Effluent Facilities } \\
\text { Administration, Section } 1.11 \text {, } \\
\text { "Radiological Protection } \\
\text { Program, " requires that specific } \\
\text { ALARA goals are prepared. The } \\
\text { facility goals implement WHC-IP- } \\
\text { l043 by establishing a facility } \\
\text { ALARA team and defining the } \\
\text { responsibilities of this team. }\end{array}$ \\
\hline
\end{tabular}


Table A-1. Identification of DOE Orders, WHC Control Manuals, and 340 Facility Implementing Documentation. (8 sheets)

\begin{tabular}{|c|c|c|c|}
\hline $\begin{array}{l}\text { Institutional } \\
\text { control or safety } \\
\text { requirement }\end{array}$ & $\begin{array}{l}\text { Federal Codes and DOE } \\
\text { Orders and titles }\end{array}$ & $\begin{array}{l}\text { Applicable WHC controlled } \\
\text { manuals }\end{array}$ & $\begin{array}{c}340 \text { Facility implementing } \\
\text { document }(s)\end{array}$ \\
\hline $\begin{array}{l}\text { Occupational } \\
\text { Safety }\end{array}$ & $\begin{array}{l}5483.1 \mathrm{~A}, \text { Occupational } \\
\text { Safety and Health } \\
\text { Program for DOE } \\
\text { Contractor Employees at } \\
\text { Government-owned } \\
\text { Contractor-operated } \\
\text { Facilities }\end{array}$ & $\begin{array}{l}\text { WHC-CM-1-3, Management } \\
\text { Requirements and Procedures } \\
\text { WHC-CM-1-10, Safety Manua } 7 \\
\text { WHC-CM-1-11, Industrial } \\
\text { Hygiene Manual } \\
\text { WHC-CM-4-2, Quality } \\
\text { Assurance Manual } \\
\text { WHC-CM-4-40, Industrial } \\
\text { Hygiene Manual }\end{array}$ & $\begin{array}{l}\text { WHC-IP-1000, } 300 \text { Area Liquid } \\
\text { Effluent Facilities } \\
\text { Administration, Section } 2.2 \text {, } \\
\text { "Shift Routine and Operating } \\
\text { Practices," requires personnel to } \\
\text { adhere to the requirements of } \\
\text { WHC-CM-1-10. The facility Safety } \\
\text { Improvement Plan requires that } \\
\text { all work be performed safely and } \\
\text { further requires that management } \\
\text { take action should safety } \\
\text { concerns be identified. }\end{array}$ \\
\hline $\begin{array}{l}\text { Fire Protection, } \\
\text { Fire Protection } \\
\text { Programs }\end{array}$ & $5480.7 \mathrm{~A}$, Fire Protection & $\begin{array}{l}\text { WHC-CM-1-3, Management } \\
\text { Requirements and Procedures } \\
\text { WHC-CM-4-41, Fire } \\
\text { Protection Program Manual }\end{array}$ & $\begin{array}{l}\text { WHC-IP-1000, } 300 \text { Area Liquid } \\
\text { Effluent Facilities } \\
\text { Administration, Section } 2.2 \text {, } \\
\text { "Shift Routine and Operating } \\
\text { Practices," will require that all } \\
\text { work be performed safely. The } \\
\text { facility is classified as a "Low } \\
\text { Fire Load" facility. Operator } \\
\text { training, the presence of smoke } \\
\text { detectors and fire sprinkler } \\
\text { systems, together with periodic } \\
\text { inspections by the fire } \\
\text { department comply with WHC-CM-4- } \\
\text { 4l. }\end{array}$ \\
\hline Industrial Safety & $\begin{array}{l}\text { None Identified (see } \\
\text { Occupational Safety) }\end{array}$ & & \\
\hline
\end{tabular}


Table A-1. Identification of DOE Orders, WHC Control Manuals, and 340 Facility Implementing Documentation. (8 sheets)

\begin{tabular}{|c|c|c|c|}
\hline $\begin{array}{l}\text { Institutional } \\
\text { control or safety } \\
\text { requirement }\end{array}$ & $\begin{array}{l}\text { Federal Codes and DOE } \\
\text { Orders and titles }\end{array}$ & $\begin{array}{l}\text { Applicable WHC controlled } \\
\text { manuals }\end{array}$ & $\begin{array}{c}340 \text { Facility implementing } \\
\text { document }(s)\end{array}$ \\
\hline Industrial Hygiene & $\begin{array}{l}5480.10, \text { Contractor } \\
\text { Industrial Hygiene } \\
\text { Program }\end{array}$ & $\begin{array}{l}\text { WHC-CM-1, Company Policies } \\
\text { and Charters } \\
\text { WHC-CM-1-3, Management } \\
\text { Requirements and Procedures } \\
\text { WHC-CM-1-10, Safety Manual } \\
\text { WHC-CM-1-11, Industrial } \\
\text { Hygiene Manual } \\
\text { WHC-CM-4-40, Industrial } \\
\text { Hygiene Manual }\end{array}$ & $\begin{array}{l}\text { WHC-IP-1000, } 300 \text { Area Liquid } \\
\text { Effluent Facilities } \\
\text { Administration, Section } 1.11 \text {, } \\
\text { "Hazard Communication", contains } \\
\text { facility specific requirements } \\
\text { for maintaining an inventory of } \\
\text { all hazardous materials. }\end{array}$ \\
\hline Criticality Safety & $\begin{array}{l}5480.24, \text { Nuclear } \\
\text { Criticality Safety }\end{array}$ & $\begin{array}{l}\text { WHC-CM-4-29, Nuclear } \\
\text { Criticality Safety Manual }\end{array}$ & $\begin{array}{l}\text { WHC-IP-1000, } 300 \text { Area Liquid } \\
\text { Effluent Facilities } \\
\text { Administration, Section } 3.10 \text {, } \\
\text { "340 Facility Critical ity Safety } \\
\text { Program" provides limited } \\
\text { facility-specific implementation } \\
\text { for the requirements of WHC-CM-4- } \\
29 \text {. The } 340 \text { Facility is } \\
\text { administratively classified as an } \\
\text { "Isolated Facility," i.e., the } \\
\text { fissile material inventory is } \\
\text { limited to no more than one-third } \\
\text { of a minimum critical mass; } \\
\text { therefore, a nuclear criticality } \\
\text { is not an issue. }\end{array}$ \\
\hline
\end{tabular}


Table A-1. Identification of DOE Orders, WHC Control Manuals, and 340 Facility Implementing Documentation. (8 sheets)

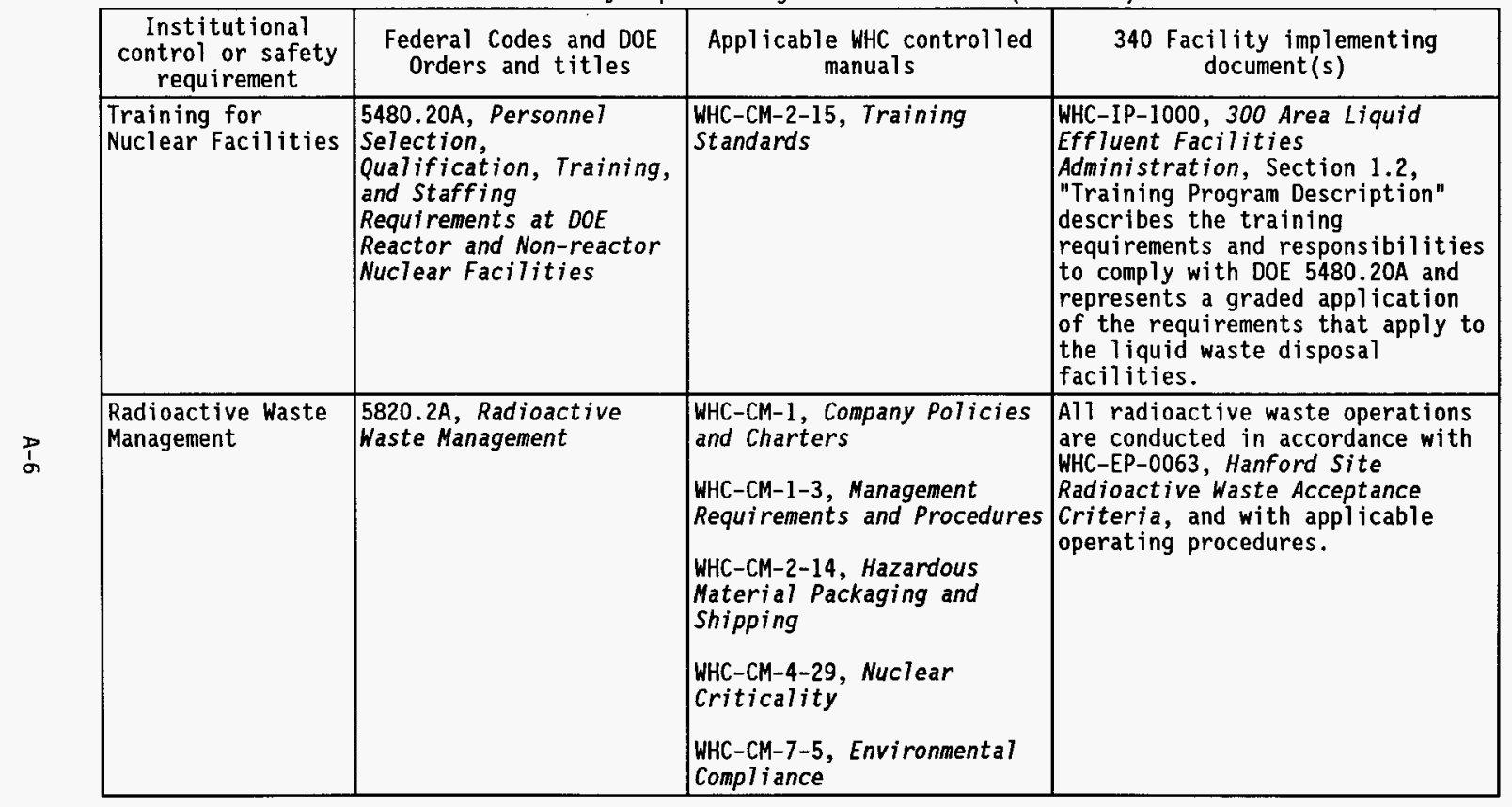


Table A-1. Identification of DOE Orders, WHC Control Manuals, and 340 Facility Implementing Documentation. (8 sheets)

\begin{tabular}{|c|c|c|c|}
\hline $\begin{array}{l}\text { Institutional } \\
\text { control or safety } \\
\text { requirement }\end{array}$ & $\begin{array}{l}\text { Federal Codes and DOE } \\
\text { Orders and titles }\end{array}$ & $\begin{array}{l}\text { Applicable WHC controlled } \\
\text { manuals }\end{array}$ & $\begin{array}{c}340 \text { Facility implementing } \\
\text { document }(s)\end{array}$ \\
\hline $\begin{array}{l}\text { Occurrence } \\
\text { Reporting }\end{array}$ & $\begin{array}{l}232.1, \text { Occurrence } \\
\text { Reporting and Processing } \\
\text { of Operations } \\
\text { Information }\end{array}$ & $\begin{array}{l}\text { WHC-CM-1-3, Management } \\
\text { Requirements and Procedures } \\
\text { WHC-CM-1-4, Correct ive } \\
\text { Actions Management Manual } \\
\text { WHC-CM-1-5, Standard } \\
\text { Operating Practices }\end{array}$ & $\begin{array}{l}\text { WHC-IP-1000, } 300 \text { Area Liquid } \\
\text { Effluent Facilities } \\
\text { Administration, Section } 1.9 \\
\text { "Occurrence Reporting," will } \\
\text { identify the occurrence reporting } \\
\text { process in accordance with WHC- } \\
\text { CM-1-5. This section will ensure } \\
\text { prompt release to the public of } \\
\text { occurrence reports, implementing } \\
\text { the requirements of DOE } \\
\text { Order } 232.1 \text {. }\end{array}$ \\
\hline Qual ity Assurance & $\begin{array}{l}10 \text { CFR } 830.120 \text {, Quality } \\
\text { Assurance }\end{array}$ & $\begin{array}{l}\text { WHC-CM-1, Company Policies } \\
\text { and Charters } \\
\text { WHC-CM-1-3, Management } \\
\text { Requirements and Procedures } \\
\text { WHC-CM-3-5, Document } \\
\text { Control and Records } \\
\text { Management Manual } \\
\text { WHC-CM-4-2, Quality } \\
\text { Assurance Manual } \\
\text { WHC-SP-1131, Rev. 1, WHC } \\
\text { Qual ity Assurance Program } \\
\text { and Implementation Plan }\end{array}$ & $\begin{array}{l}\text { WHC-IP-1000, } 300 \text { Area Liquid } \\
\text { Effluent Facilities } \\
\text { Administration, Section } 1.4 \text {, } \\
\text { "Quality Assurance Program Plan," } \\
\text { provides guidance for } \\
\text { implementation of the } 19 \text { elements } \\
\text { defined by WHC-CM-4-2, QR } 1.0 \\
\text { through QR } 19.0 \text {. }\end{array}$ \\
\hline
\end{tabular}


Table A-1. Identification of DOE Orders, WHC Control Manuals, and 340 Facility Implementing Documentation. ( 8 sheets)

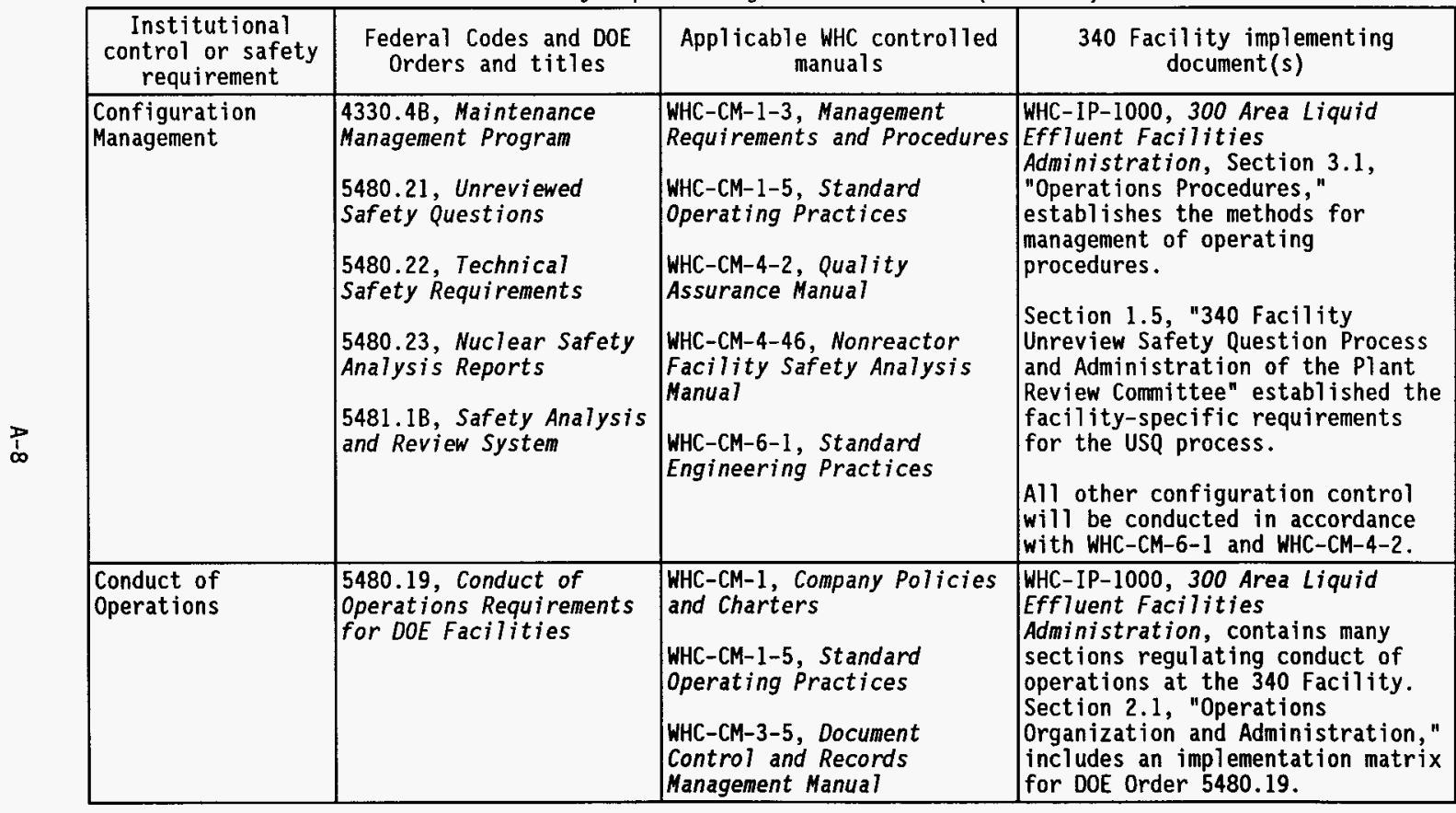


Table A-1. Identification of DOE Orders, WHC Control Manuals, and 340 Facility Implementing Documentation. (8 sheets)

\begin{tabular}{|c|c|c|c|}
\hline $\begin{array}{l}\text { Institutional } \\
\text { control or safety } \\
\text { requirement }\end{array}$ & $\begin{array}{c}\text { Federal Codes and DOE } \\
\text { Orders and titles }\end{array}$ & $\begin{array}{l}\text { Applicable WHC controlled } \\
\text { manuals }\end{array}$ & $\begin{array}{c}340 \text { Facility implementing } \\
\text { document }(s)\end{array}$ \\
\hline Emergency Planning & $\begin{array}{l}5500.2 \mathrm{~B}, \text { Emergency } \\
\text { Categories, Classes, and } \\
\text { Notification and } \\
\text { Reporting Requirements } \\
5500.3 \mathrm{~A}, \text { Planning and } \\
\text { Preparedness for } \\
\text { Operational Emergencies }\end{array}$ & $\begin{array}{l}\text { WHC-CM-1, Company Policies } \\
\text { and Charters } \\
\text { WHC-CM-1-3, Management } \\
\text { Requirements and Procedures } \\
\text { WHC-CM-4-43, Emergency } \\
\text { Management Procedures }\end{array}$ & $\begin{array}{l}\text { The building emergency plan is } \\
\text { contained in WHC-IP-0263-340, } \\
\text { Building Emergency Plan, 340 } \\
\text { Waste Handling Facility. This } \\
\text { document has been prepared in } \\
\text { accordance with WHC-CM-4-43. }\end{array}$ \\
\hline $\begin{array}{l}\text { Environmental } \\
\text { Protection }\end{array}$ & $\begin{array}{l}5400.1, \text { General } \\
\text { Environmental Protection } \\
\text { Program } \\
5400.5, \text { Radiation } \\
\text { Protection of the Public } \\
\text { and the Environment } \\
5480.4, \text { Environmental } \\
\text { Protection, Safety, and } \\
\text { Health Protection } \\
\text { Standards } \\
5484.1, \text { Environmental } \\
\text { Protection, Safety, and } \\
\text { Health Protection } \\
\text { Information Reporting } \\
\text { Requirements }\end{array}$ & $\begin{array}{l}\text { WHC-CM-1, Company Policies } \\
\text { and Charters } \\
\text { WHC-CM-1-3, Management } \\
\text { Requirements and Procedures } \\
\text { WHC-CM-1-4, Corrective } \\
\text { Action Management Manual } \\
\text { WHC-CM-4-2, Qual ity } \\
\text { Assurance Manual } \\
\text { WHC-CM-7-5, Environmental } \\
\text { Compliance Manual }\end{array}$ & $\begin{array}{l}\text { ISB-003 addresses environmental } \\
\text { monitoring within the } 340 \\
\text { Facility and specifies periodic } \\
\text { formal and informal audits to } \\
\text { assure conformance to limits and } \\
\text { safe practices. } \\
\text { Compliance with environmental } \\
\text { protection is implemented through } \\
\text { WHC-CM-7-5. Tracking of } \\
\text { corrective actions is implemented } \\
\text { through WHC-CM-1-4. }\end{array}$ \\
\hline
\end{tabular}




\section{REFERENCES}

\section{U.S. FEDERAL CODES AND DEPARTMENT OF ENERGY ORDERS}

10 CFR 830.120, Quality Assurance, Code of Federal Regulations, as ammended.

10 CFR 835, Occupational Radiation Protection, Code of Federal Regulations, as ammended.

DOE Order 232.1, Occurrence Reporting and Processing of Operations Information, U.S. Department of Energy, Washington, D.C.

DOE Order 4330.4B, Maintenance Management Program, U.S. Department of Energy, Washington, D.C.

DOE Order 5400.1, General Environmental Protection Program, U.S. Department of Energy, Washington, D.C.

DOE Order 5400.5, Radiation Protection of the Public and the Environment, U.S. Department of Energy, Washington, D.C.

DOE Order 5480.4, Environmental Protection, Safety, and Health Protection Standards, U.S. Department of Energy, Washington, D.C.

DOE Order 5480.7, Fire Protection, U.S. Department of Energy, Washington, D.C.

DOE Order 5480.10, Contractor Industrial Hygiene Program, U.S. Department of Energy, Washington, D.C.

DOE Order 5480.11, Radiation Protection for Occupational Workers, U.S. Department of Energy, Washington, D.C.

DOE Order 5480.19, Conduct of Operations Requirements for DOE Facilities, U.S. Department of Energy, Washington, D.C.

DOE Order 5480.20A, Personnel Selection, qualification, Training, and Staffing Requirements at DOE Reactor and Non-reactor Nuclear Facilities,

U.S. Department of Energy, Washington, D.C.

DOE Order 5480.21, Unreviewed Safety Questions, U.S. Department of Energy, Washington, D.C.

DOE Order 5480.22, Technical Safety Requirements, U.S. Department of Energy, Washington, D.C.

DOE Order 5480.23, Nuclear Safety Analysis Reports, U.S. Department of Energy, Washington, D.C.

DOE Order 5480.24, Nuclear Criticality Safety, U.S. Department of Energy, Washington, D.C.

DOE Order 5483.1A, Occupational Safety and Health Program for DOE Contractor Employees at Government-owned Contractor-operated Facilities, 


\section{U.S. Department of Energy, Washington, D.C.}

DOE Order 5484.1, Environmental Protection, Safety, and Health Protection Information Reporting Requirements, U.S. Department of Energy, Washington, D.C.

DOE Order 5500.2B, Emergency Categories, Classes, and Notification and Reporting Requirements, U.S. Department of Energy, Washington, D.C.

DOE Order 5500.3A, Planning and Preparedness for Operational Emergencies, U.S. Department of Energy, Washington, D.C.

DOE Order 5820.2A, Radioactive Waste Management, U.S. Department of Energy, Washington, D.C.

N 441.1, Radiological Protection for DOE Activities, U.S. Department of Energy, Washington, D.C.

\section{WESTINGHOUSE CONTROLLED MANUALS}

HSRCM-1, Hanford Site Radiological Control Manual, Hanford Contractors Richland, Washington.

WHC-CM-1, Company Policies and Charters, Westinghouse Hanford Company, Richland, Washington.

WHC-CM-1-3, Management Requirements and Procedures, Westinghouse Hanford Company, Richland, Washington.

WHC-CM-1-4, Corrective Actions Management Manual, Westinghouse Hanford Company, Richland, Washington.

WHC-CM-1-5, Standard Operating Practices, Westinghouse Hanford Company, Richland, Washington.

WHC-CM-1-10, Safety Manual, Westinghouse Hanford Company, Richland, Washington.

WHC-CM-1-11, Industrial Hygiene Manual, Westinghouse Hanford Company, Richl and, Washington.

WHC-CM-2-14, Hazardous Material Packaging and Shipping, Westinghouse Hanford Company, Richland, Washington.

WHC-CM-2-15, Training Administration Manual, Westinghouse Hanford Company, Richland, Washington.

WHC-CM-3-5, Document Control and Records Management Manual, Westinghouse Hanford Company, Richland, Washington.

WHC-CM-4-2, Quality Assurance Manual, Westinghouse Hanford Company, Richland, Washington. 
WHC-CM-4-5, Quality Assurance Qualifications and Instructions, Westinghouse Hanford Company, Richland, Washington.

WHC-CM-4-29, Nuclear Criticality Safety Manual, Westinghouse Hanford Company, Richl and, Washington.

WHC-CM-4-40, Industrial Hygiene Manual, Westinghouse Hanford Company, Richland, Washington.

WHC-CM-4-41, Fire Protection Program Manual, Westinghouse Hanford Company, Richl and, Washington.

WHC-CM-4-46, Nonreactor Facility Safety Analysis Manual, Westinghouse Hanford Company, Richland, Washington.

WHC-CM-6-1, Standard Engineering Practices, Westinghouse Hanford Company, Richland, Washington.

WHC-CM-7-5, Environmental Compliance Manual, Westinghouse Hanford Company, Richl and, Washington.

WHC-IP-1043, WHC Occupational Alara Program, Westinghouse Hanford Company, Richl and, Washington.

WHC-IP-1000, 300 Area Liquid Effluent Facilities Administration, Westinghouse Hanford Company, Richland, Washington.

WHC-SP-1131, Rev. 1, WHC Quality Assurance Program and Implementation Plan, Westinghouse Hanford Company, Richland, Washington. 
WHC-SD-WM-ISB-003 REV 1

APPENDIX B

CALCULATION OF SPRAY RELEASE

B-1 


\section{WHC-SD-WM-ISB-003 REV 1}

This page intentionally without substantive content. 


\section{CALCULATION OF SPRAY RELEASE}

Calculation of the spray release from the Vault Tank piping used equations from WHC-SD-GN-TI-30003 and WHC-SD-GN-SWD-20007. The calculations were done on a spreadsheet iterating first to find the Reynolds number and then to find the slit width giving the highest respirable flow. The Reynolds number 3230 indicates a critical flow. Subscripts were changed in some of the equations for consistency.

The following variable constants define the system.

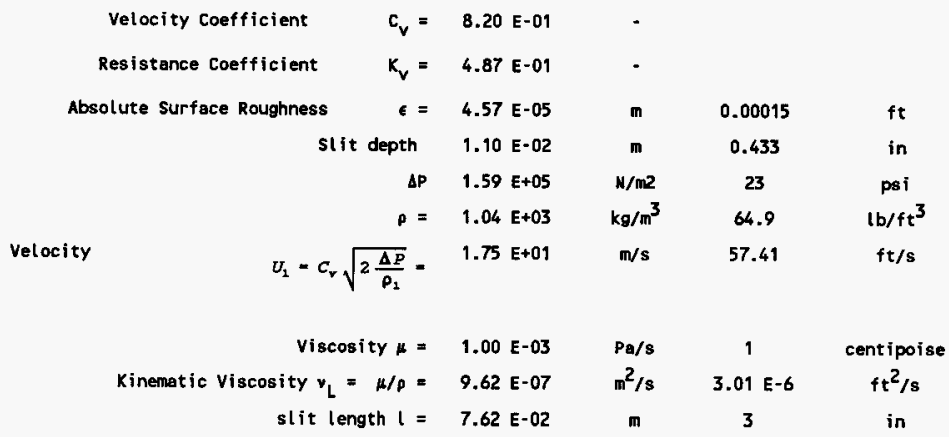

The respirable portion was calculated using Saunter Mean Diameter $S M D=\frac{500 d_{\theta}^{1.2} v_{L}^{0.2}}{U_{L}}$ and the Rosin-Rammler drop size distribution
$Q=1-e^{-\left(D_{x} / x\right)^{Q}}$

SMD using the Rosin Rammler drop size distribution $\frac{S M D}{X}=\left[\Gamma\left(1-\frac{1}{q}\right)\right]^{-1}$

Where: $\quad \Gamma$ denotes the gamma function

To calculate the Saunter Mean Diameter (SMD) and drop size distribution the following variable constants were assumed. The value of $q$ and the corresponding value of SMD/X were taken from Page 3 of WHC-SD-GN-TI-30003

$\begin{array}{crc}\text { Respirable drop size } & D_{\mathbf{r}}= & 20 \\ \text { A fitting Constant } & q= & 2.4 \\ \text { Based on q } & \text { SMD } / X= & 0.65415\end{array}$




\section{WHC-SD-WM-ISB-003 REV 1}

The calculation sequence giving the equations in the sequence used and the final result follows.

$$
\begin{aligned}
& \text { slit width } w=1.943 \mathrm{E}-04 \\
& \text { Equivalent diameter } 2 *_{W}=d_{e}=3.89 \mathrm{E}-04 \\
& \text { depth/de }=2.83 \mathrm{E}+01 \\
& \epsilon / d_{e}=1.18 \mathrm{E}-01 \\
& \text { Estinated Reynolds number } R_{e}=\quad 3.25 \mathrm{E}+03 \\
& \frac{1}{\sqrt{t_{d}}}=-2 \log _{10}\left(\frac{e / d_{d}}{3.7}+\frac{2.51}{R_{d} \sqrt{T_{d}}}\right) \text { est1mated } f_{d}=\quad 1.16 \mathrm{E}-09 \\
& \epsilon / \mathrm{d}_{\mathrm{e}} / 3.7=\quad 3.18 \mathrm{E}-02 \\
& 2.51 / R_{e}{ }^{* f}{ }^{1 / 2}=\quad 2.27 E-03 \\
& -2 * \log \left(\epsilon / \mathrm{d} \mathrm{e}^{\left./ 3.7+2.51 / R^{* * f} f^{1 / 2}\right)}=\quad 2.94 \mathrm{E}+00\right. \\
& \text { fd } 1.16 \mathrm{E}-01 \\
& k_{f} \quad 3.28 E+00 \\
& K+1=K_{f}+K_{v}+1=\quad 4.77 \mathrm{E}+00 \\
& \text { Liquid jet velocity } \quad 8.00 \mathrm{E}+00 \\
& v_{L}=\sqrt{\frac{2 \Delta P}{\rho(k+1)}}= \\
& \text { Reynolds nuiber } \quad R_{\varepsilon}=\frac{D_{c} O_{L} \mathrm{P}}{\mu}=3.23 \mathrm{E}+03 \\
& S M D=\frac{500 d_{\cdot}^{1.7} v_{L}^{0.2}}{\sigma_{L}}= \\
& 3.16 \mathrm{E}+02 \\
& Q=1-e^{-\left(D_{x} / \frac{100}{x^{2}}\right)}= \\
& 4.79 \mathrm{E}-04 \\
& \text { Total spray flow rate }=W_{t}=C_{v} A V_{L}= \\
& 1.18 \mathrm{E}-04 \\
& \mathrm{~m} 3 / \mathrm{s} \\
& 3.12 \mathrm{E}-2 \quad \mathrm{gal} / \mathrm{s} \\
& \text { Release flow rate }=w_{Q}=Q w_{\mathrm{c}}= \\
& 5.68 E-08 \\
& \mathrm{m3} / \mathrm{s} \\
& 1.58 E-5 \\
& \text { gal/s } \\
& \text { Total22 volume released }=150 \text { min*60 s* } \mathrm{w}_{t}= \\
& 1.07 \mathrm{E}+00 \\
& 5.11 \text { E-04 }
\end{aligned}
$$

$\begin{array}{lll}k L & 2.75 E+02 & \text { gal } \\ k L & 1.32 E-01 & \text { gal }\end{array}$




\section{WHC-SD-WM-ISB-003 REV I}

\section{APPENDIX $\mathbf{C}$ \\ GENII DOSE CONSEQUENCE CALCULATION}

FOR THE 340 FACILITY 
WHC-SD-WM-ISB-003 REV 1

This page intentionally without substantive content. 
From: Criticality \& Radiological Analyses

Phone: $376-9710 \mathrm{H4}-64$

$\begin{array}{ll}\text { Date: } & \text { September } 19,1994 \\ \text { Subject: } & \text { GENII DOSE CONSEQUENCE CALCULATION FOR THE } 340 \text { FACILITY }\end{array}$

$\begin{array}{ll}\text { Date: } & \text { September } 19,1994 \\ \text { Subject: GENII DOSE CONSEQUENCE CALCULATION FOR THE } 340 \text { FACILITY }\end{array}$

LVN-8D150-94-013

To:

D. 3. Johnson H4-70
CC:
J. S. Davis
H4-64
J. P. Estrellado, Jr.
H4 -70
B. E. Hey
J. C. Van Keuren
H4-64
J. W. Daughtry
H. $4-64$
LVN $\mathrm{Fi}$ ]e/LB
H4-64

As requested, radiological dose consequence calculations for the 340 facility have been completed. Doses were calculated for a release of $1 \mathrm{Ci}$ of the isotopes specified by the customer. The computer codes used in this analys is were GENII version 1.485 and $Q X Q$ Version 3.1 . The results are reported in the attachment.

If you have any questions, please call me on 376-9710.

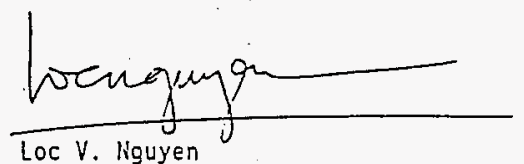

Engineer

sin'

Attachment

Concurrence:<smiles>[CH2][C@H]1CC[C@H]1C</smiles><smiles>[CH]1C=C1</smiles> 


\section{GENII DOSE CONSEQUENCE CALCULATION \\ FOR THE 340 FACILITY}

L. V. Nguyen

September 20, 1994

\section{PURPOSE}

Potential maximum individual dose consequences to the onsite 100 meter and site boundary receptors from the postulated accident involving the 340 facility radioactive inventory have been calculated. The accident was evaluated as a ground-level release.

\section{SOURCE TERMS}

The source torms yere 1 ci of each isgtape as specified by the customer in Appendix A. The release was assumed to be in the form of oxide.

\section{METHODOLOGIES AND ASSUMPTIONS}

Acute maximum individual ground level release 99.5 percentile dispersion factors (X/Q) were generated using EXQ Version 3.1 (B. E. Hey, 1993) for 16 onsite 100-meter and site boundary locations. In addition, the onsite 100meter and site boundary overall average 95 percentile $X / Q$ s were determined using GXQ to compare with the maximum sector individual $X / Q$. The higher $X / Q$ will be used for dose calculations (NRC Regulatory Guide 1.145).

\section{RECEPTOR DESCRIPTION}

- Onsite: For the ground level releases, the receptor is normally $100 \mathrm{~m}$ in the worst direction (WHC-CM-4-46). Doses calculated for the onsite receptor include inhalation and submersion. The onsite maximum individual $X / Q$ at 100 meters was calculated for 16 sectors. The maximum onsite individual for acute ground level release from the 340 Facility was calculated to be located at 100 meters north, with an acute 99.5 percentile $X / Q$ of 4.21 E-02 s/m $X / Q$ for all 10 sectors are listed in Table 1 . The asterisk in Tabie 1 identifies the worst onsite $X / Q$.

- Site Boundary: The site boundary receptor is located at the site boundary in the worst direction. Where the site is bounded by the Columbia River, the site boundary is taken to be at the nearer bank. of the river for maximum individual doses. This receptor is assumed to stay at this location for the duration of the accident. Doses calculated include inhalation and submersion. The maximum offsite individual 99.5 percentile $X / Q$ for an acute ground level release from the 340 Facility is $3.77 \mathrm{E}-03 \mathrm{~s} / \mathrm{m}^{3}$ ( 345 meters E). The asterisk in Table 2 identifies the worst site boundary $X / Q$.

$$
Y
$$


CODE DOCUMENTATION

- GENII version $1.485(12 / 3 / 90)$

- GENII Default Parameter Values (28-Mar-90 RAP)

- Radionuclide Master Library (7/23/93 PDR)

- PNL Food Transfer Factor Library (7/19/93)

- External Dose Factor Library (8-May-90-RAP)

- Internal Dose Increments, PNL Solubilities, (7/23/93 POR)

- Joint Frequency Data: 300 Area, $10 \mathrm{~m}$, Pasquill A-G (19831991 Average)

- GXQ Version 3.1 (1993)

A typical GENII and GXQ input files are attached as Appendix $B$ and $C$.

\section{RESULTS}

The resulting effective dose equivalents (EDE) and limiting organ doses for onsite and offsite receptors calculated by GENII with 99.5 percentile meteorology are shown in Tables 3 and 4 . Inhalation doses were 50-year committed doses based on an acute uptake. Submersion doses were calculated using a semi-infinite cloud model.

Any external dose due to plume submersion was included in both the EDE and organ dose for GENII calculations. Building wake and piume meander were not taken into account as requested by the customer.

HOTE: Please, be aware of the fact that the new joint frequency data, and NRC Regulatory Guide 1.145 (Ref. 4) atmospheric dispersion coefficient $(X / Q)$ method's were applied for dose calculations. These changes may affect consistency with previous $X / Q s$ and dose consequences. This document is based on the best available information at this time.

Note: When using the unit release consequences presented in this document, note that (a) release fractions considering only respirable size particles may not be appropriate for determining source term ratios, (b) scaling of unit release consequences may not be appropriate for changes other than source term quantity, and (c) the technical peer review for unit release consequences does not cover consequences scaled from the unit release consequences. Scaled consequences must also be reviewed by Radiological \& Toxicological Analysis or their designees, as required in SA\&E Work Procedure 6.2 (WHC-CM-6-32). In general, the HEDOP review of the original analysis is sufficient.

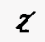


Tabie 1: Acute 99:5 Percentile X/Qs in 16 Sectors, and 95 Percentile Overal1 Average $X / Q$ for 100 Meters, all for Ground Level Releas̉es.

\begin{tabular}{|c|c|}
\hline sector & Dispersion factors $\times 10\left(\mathrm{~s} / \mathrm{m}^{3}\right)$ \\
\hline 5 & $3.18 E-02$ \\
\hline ssh & $1.16 \Xi-02$ \\
\hline SH & $4.39 E \cdot 03$ \\
\hline 45W & $3.88 E-03$ \\
\hline$\omega$ & $1.51 E-02$ \\
\hline WWH & $2.90 E-02$ \\
\hline NH & $3.28 E-02$ \\
\hline NNW & $3.29 E-02$ \\
\hline H & $6.21 \leqq-02 *$ \\
\hline NME & $2.89 \equiv .02$ \\
\hline HE & $2.93 \pm-02$ \\
\hline ENE & $1.60 \mathrm{E}-02$ \\
\hline$\underline{E}$ & $3.16 \overline{\mathrm{z}}-02$ \\
\hline ESE & $2.99 \pm .02$ \\
\hline SE & $3.16 \mathrm{E}-02$ \\
\hline SSE & $3.23 .5-02$ \\
\hline OVERALL 95 PERCENTILE $\times 10$ & $3.46 E-02$ \\
\hline
\end{tabular}


Table 2: Acute 99.5. Percentile X/Qs-at Site Boundary Locations for Ground Level Release from 340 Facility.

\begin{tabular}{|c|c|c|}
\hline Sector & Distance (m) & Dispersion Facrors $\times / 0\left(\mathrm{~s} / \mathrm{m}^{3}\right)$ \\
\hline 5 & 6475 & $4.25 E-0.5$ \\
\hline 55H & 2590 & $5.36 E=05$ \\
\hline SW & 3515 & $1.32 E-05$ \\
\hline HSW & 3515 & $1.01 E-05$ \\
\hline 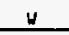 & 6575 & $1.88 E-05$ \\
\hline WNW & 28675 & $6.02 E-06$ \\
\hline NH & 49025 & 3.54 E-06 \\
\hline NHW & 51800 & $3.33 \mathrm{E}=0.06$ \\
\hline$\forall$ & 17020 & $1 . \leq 5 \leq-05$ \\
\hline HNE & 505 & $1.83 \mathrm{E}-03$ \\
\hline NE & 505 & $1.85 \varepsilon-03$ \\
\hline ENE & 345 & $1.90=-03$ \\
\hline$E$ & 345 & $3 . \pi \pm .03=$ \\
\hline ESE & 365 & $3.58 E-03$ \\
\hline SE & 535 & $1.81 \mathrm{E}-03$ \\
\hline SSE & 830 & $8.89 \pm-04$ \\
\hline \multicolumn{2}{|c|}{ Overall sector 95 percentile } & $1.51 E-03$ \\
\hline
\end{tabular}


Table 3. Maximum Individual Doses for Onsite 100 Meter Receptor Due to an Aerosol Release of $1 \mathrm{Ci}$ of Each Isotope from 340 Facility

\begin{tabular}{|c|c|c|}
\hline Radionuctide & $\begin{array}{c}\text { External Dose } \\
\text { (rem) }\end{array}$ & $\begin{array}{c}\text { Anual Effective Dose Equivalent } \\
\text { (ren) }\end{array}$ \\
\hline Mut 56 & $7.0=-03$ & 9.6 E-02 \\
\hline $\mathrm{co} 60$ & $2.1 E-02$ & $9.6 \mathrm{E}+00^{\circ}$ \\
\hline SR 90 & $1.7 \mathrm{E}-06$ & $2.8 E+00$ \\
\hline$Y 90$ & $6.1 E-05$ & $1.2 \mathrm{E}-0 \mathrm{t}$ \\
\hline ZR 95 & $6.3 \mathrm{E}-03$ & 2.2 E-01 \\
\hline NB 95 & 7.0 E-03 & $8.7 \mathrm{E}-02$ \\
\hline ic 9 & $3.2 \mathrm{E}-07$ & $1.3 E-01$ \\
\hline RU 106 & $2.0 E-03$ & $0.6 E-00$ \\
\hline SB 125 & $4.0 E-03$ & $1.8 E-01$ \\
\hline CS 134 & $1.4 \mathrm{E}-02$ & $6.1 \mathrm{E} .01$ \\
\hline es 137 & $6.7 E-03$ & 4,3 E-01 \\
\hline CE 164 & $1.2 \mathrm{E}-04$ & $5.2 E+00$ \\
\hline Eu 152 & $1.0 \mathrm{E}-02$ & $2.9 E+00$ \\
\hline EU 156 & $1.0 \mathrm{E}-02$ & $3.9 E+00$ \\
\hline 외 155 & $3.5 \mathrm{E}-04$ & $5.7 \mathrm{E}-01$ \\
\hline IA 182 & $1.1 \mathrm{E}-02$ & $6.2 \mathrm{E}-01$ \\
\hline$U \quad 234$ & 1.7 E.06 & $1.9 E-03$ \\
\hline$\cup \quad 235$ & $0.0 E+00$ & $1.7 \mathrm{E}+03$ \\
\hline U 236 & $1.3 \mathrm{E}-06$ & $1.8 \mathrm{E}+03$ \\
\hline PU 238 & $1.3 \mathrm{E}-06$ & 4.0 E+03 \\
\hline $4 \quad 238$ & $1.2 E-06$ & $1.7 \mathrm{E}+03$ \\
\hline PU 239 & $8.8 E-07$ & $4.3 \mathrm{E}+03$ \\
\hline PU 260 & $1.3 E .06$ & $4.2 \mathrm{E}+03$ \\
\hline 소 24 & $9.0=0.05$ & $6.2 E+03$ \\
\hline PU 261 & $3.1 \mathrm{E}-12$ & $6.9 \mathrm{E}+01$ \\
\hline $\mathrm{CX} 262$ & $1.3 \mathrm{E}-0 \mathrm{~S}$ & $2.4 E+02$ \\
\hline py 262 & $0.0 E+00$ & $4.1 E+03$ \\
\hline
\end{tabular}


Table 4. Maximum Individual Doses Calculated for Site Boundary Receptor at $345 \mathrm{mE}$, Due to An Aerosol Release of $1 \mathrm{Ci}$ of Each Isotope from 340 Facility

\begin{tabular}{|c|c|c|}
\hline Radionuelide & $\begin{array}{c}\text { External Dose } \\
\text { (rem) }\end{array}$ & $\begin{array}{c}\text { Annual Effective Dose Equivalent } \\
\text { (rem) }\end{array}$ \\
\hline MN 54 & $6.5 E-04$ & $8.3 E-03$ \\
\hline$C 060$ & $1.9 \mathrm{E} \cdot 03$ & 2.4 E-01 \\
\hline SR 90 & 1.6 E-07 & $2.4 E-01$ \\
\hline$Y 90$ & $5.6 \mathrm{E} .06$ & 1.0 E-02 \\
\hline ZR 95 & 5.8 E-OG & $1.9 \mathrm{E}-02$ \\
\hline NB 95 & $6.5 E-04$ & $7.5 \mathrm{E}+03$ \\
\hline IC 99 & $2.9 E-08$ & $1.1 \mathrm{E}-02$ \\
\hline RU 106 & $1.8 E-04$ & $5.6 \mathrm{E} .09$ \\
\hline SB 125 & $3.7 \pm-04$ & 1.6 E- 02 \\
\hline cs 134 & $1.3 E-03$ & $5.2 \mathrm{E}-02$ \\
\hline Cs 137 & $4.4=-0.4$ & $3.6 \mathrm{E}-02$ \\
\hline CE 144 & $1.1 E-05$ & $4.5 \mathrm{E}-01$ \\
\hline EU 152 & $9.2 \equiv-04$ & $2.5 \mathrm{E}-09$ \\
\hline EU 154 & 9.4 E-04 & $3.3=-01$ \\
\hline EU 155 & $3.2 \equiv-05$ & $4.9 E-02$ \\
\hline TA 182 & $1.0 \pm-03$ & $5.3 \mathrm{E}-02$ \\
\hline U 234 & $1.6 \mathrm{E}-07$ & $1.6 \mathrm{E}+02$ \\
\hline U 235 & $0.0 \pm+00$ & $1.5 E=02$ \\
\hline v 236 & 1.2 E-07 & $1.5 E+02$ \\
\hline U 238 & $1.1 E-07$ & $1.4 \mathrm{E}-02$ \\
\hline PU 239 & $8.1 E .08$ & $3.6 E+02$ \\
\hline PU 240 & $1.2 \mathrm{E}-07$ & $3.6 E+02$ \\
\hline AH 241 & $2.9 E-13$ & $5.9 \mathrm{E}+00$ \\
\hline PU 249 & $8.3 E=06$ & $5.3 E+02$ \\
\hline CH 242 & $1.2 E-07$ & $2.0 \mathrm{E}+01$ \\
\hline PU 242 & $0.05+00$ & $3.5 \mathrm{E}+02$ \\
\hline
\end{tabular}




\section{WHC-SD-HM-ISB-003 REV I}

\section{REFERENCES}

Napier, B. A., et a1., 1988, GENII - The Hanford Environmental Radiation Dosimetry Software System, PNL-6484, Pacific Northwest Laboratory, Richland, Washington.

Hey, B. E., 1993, GXQ Program Users' Guide, WHC-SD-GN-SWD-30002, Westinghouse Hanford Company, Richland, Washington.

WHC-CM-4-46, Nonreactor Facility Safety Analysis Manual, "Westinghouse Hanford Company, Richland, Washington.

U.S. Nuclear Regulatory Commission, November 1982, Atmospheric Dispersion Models For Potential Accident Consequence Assessments At Nuclear Power Plants, Regulatory Guide 1.145, Revision 1, Office of Nuclear Regulatory Research. 
WHC-SD-WM-ISB-003 REV 1

APPENDIX A

CC: MAIL FROM D. J. JOHNSON TO J. C. VAN KEUREN

DATE: September 14, 1994 
WHC-SD-WM-ISB-003 REV 1

\begin{tabular}{|c|c|}
\hline \multicolumn{2}{|c|}{340 Vsult tanks expeeted isotopes } \\
\hline Isotopes & $\mathrm{ci}$ \\
\hline $54 \mathrm{Mn}$ & 1.0 \\
\hline${ }^{60} \mathrm{Co}$ & 1.0 \\
\hline $90^{25}$ & 1.0 \\
\hline${ }^{95} \mathrm{Zr}$ & 1.0 \\
\hline $95 \mathrm{Nb}$ & 1.0 \\
\hline $99_{\mathrm{TC}}$ & 1.0 \\
\hline $106_{\mathrm{RU}}$ & 1.0 \\
\hline $125_{\mathrm{sb}}$ & 1.0 \\
\hline${ }^{134} \mathrm{cs}$ & 1.0 \\
\hline${ }^{137} \mathrm{cs}$ & 1.0 \\
\hline${ }^{144} \mathrm{Ce}$ & 1.0 \\
\hline $152_{5 U}$ & 1.0 \\
\hline${ }^{154} \mathrm{Eu}$ & 1.0 \\
\hline${ }^{155_{\mathrm{u}}}$ & 1.0 \\
\hline${ }^{182}$ Ta $_{\text {a }}$ & 1.0 \\
\hline $234 \mathrm{U}$ & 1.0 \\
\hline $235 u$ & 1.0 \\
\hline $236 \mathrm{U}$ & 1.0 \\
\hline 238 & 1.0 \\
\hline $238_{\mathrm{Pu}}$ & 1.0 \\
\hline $239 / 240_{\mathrm{Pu}}$ & 1.0 \\
\hline $240 \mathrm{Pu}$ & 1.0 \\
\hline $241_{P U}$ & 1.0 \\
\hline${ }^{242} \mathrm{Pu}$ & 1.0 \\
\hline $249_{\mathrm{Am}}$ & 1.0 \\
\hline $242 / 243 \mathrm{~cm}$ & 1.0 \\
\hline
\end{tabular}


WHC-SD-WM-ISB-003 REV 1

APPENDIX B

SAMPLE GENII INPUT DECK

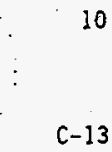




\section{ONSITE 100 METERS ACUTE GROUND LEVEL INDIVIDUAL RELEASE}

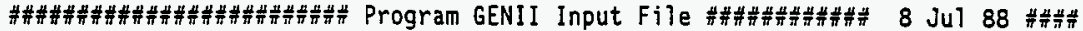
Title: ACUTE ONSITE INDIVIDUAL DOSES FOR $X / Q$ OF 4.21 E-02 RELEASE \SAMPL \G-AIR.AC

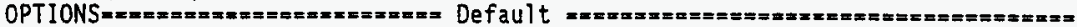

$\begin{array}{ccccc}F & \text { Near-field scenario? } & \text { (Far-field) } & \text { NEAR-FIELD: narrowly-focused } \\ \mathrm{F} & \text { Population dose? } & \text { (Individual) } & \text { release, single site } \\ \mathrm{T} & \begin{array}{c}\text { Acute release? } \\ \text { Maximum Individual data set used } \\ \text { Complete }\end{array} & \text { FAR-FIELD: } & \begin{array}{l}\text { wide-scale release, } \\ \text { multiple sites }\end{array} \\ & & & \text { Complete }\end{array}$

TRANSPORT OPTIONS $=m=m=m=====$ Section

EXPOSURE PATHWAY OPTIONS $===\approx=$ Section

F Surface Water Transport

$F$ Finite plume, external

F Biotic Transport (near-fieid) 3,4

$F$ Waste Form Degradation (near) 3,4

REPORT OPTIONS $m=m=m=x=m=x=========$

$T$ Infinite piume, external

$F$ Ground, external

$F$ Recreation, external

T Inhalation uptake

5

$T$ Report AEDE only

$T$ Report by radionuclide

F Drinking water ingestion

5

$T$ Report by exposure pathway

F Aquatic foods ingestion

F Terrestrial foods ingestion

$F$ Animal product ingestion

$F$ Inadvertent soil ingestion

$F$ Debug report on screen

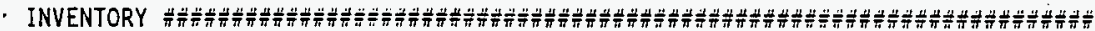

4 Inventory input activity units: (1-pCi 2-uCi 3-mCi 4-Ci 5-Bq)

0 Surface soil source units (1- $\mathrm{m}_{2} 2-\mathrm{m} 3 \quad 3-\mathrm{kg}$ )

Equilibrium question goes here

\begin{tabular}{|c|c|c|c|c|c|c|c|c|}
\hline Use when & & port sel & ected & & field sc & enario & optiona & \\
\hline $\begin{array}{l}\text { Release } \\
\text { Radjo- } \\
\text { nuclide }\end{array}$ & $\begin{array}{l}\text { Air } \\
/ y r\end{array}$ & $\begin{array}{l}\text { Surface } \\
\text { Water } \\
\text { /yr }\end{array}$ & $\begin{array}{l}\text { Buried } \\
\text { Waste } \\
/ \mathrm{m} 3\end{array}$ & $\begin{array}{l}\text { Air } \\
/ \pi 3\end{array}$ & $\begin{array}{l}\text { Surface } \\
\text { Soil } \\
\text { /unit }\end{array}$ & $\begin{array}{l}\text { Deep } \\
\text { Soif } \\
/ \pi 3\end{array}$ & $\begin{array}{l}\text { Ground } \\
\text { Water } \\
/ \mathrm{L}\end{array}$ & $\begin{array}{l}\text { Surface } \\
\text { Water } \\
\text { /L }\end{array}$ \\
\hline
\end{tabular}

MN54 $\quad 1.0$

C060 $\quad 1.0$

AM241 1.0

$\operatorname{cs} 137 \quad 1.0$

CS134 1.0

CEI44 1.0

CM242 1.0

EU152 1.0

EU154 1.0

EUI55 1.0

SR9O 1.0

$Y 90 \quad 1.0$

ZR95 1.0

NB95 1.0

TC99 1.0

RU106 1.0 


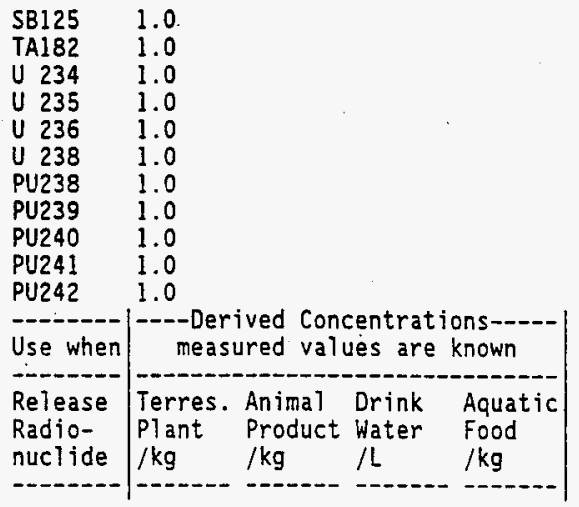

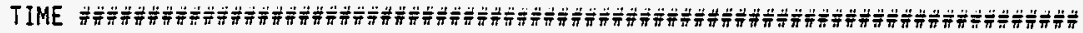

1 Intake ends after (yr)

50 Dose calc. ends after (yr)

0 Release ends after ( $y r)$

0 No. of years of air deposition prior to the intake period

0 No. of years of irrigation water deposition prior to the intake period

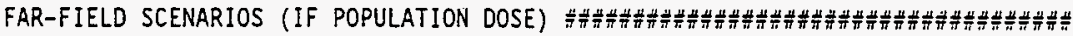

0 Definition option: 1-Use population grid in file POP. IN

0 2-Use total entered on this line

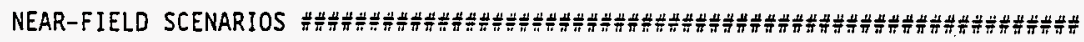

Prior to the beginning of the intake period: (yr)

0 When was the inventory disposed? (Package degradation starts)

$0 \quad$ When was LOIC? (Biotic transport starts)

$0 \quad$ Fraction of roots in upper soil (top $15 \mathrm{~cm}$ )

$0 \quad$ Fraction of roots in deep soil

0 Manual redistribution: deep soil/surface soil dilution factor

$0 \quad$ Source area for external dose modification factor (m2)

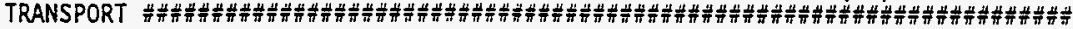

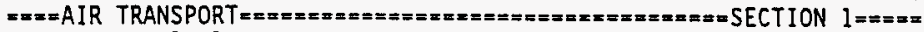

$0-$ Calculate PM

1

4.21E-2

Option: 1-Use chi/Q or PM value 2-Select MI dist \& dir 3-Specify MI dist \& dir Chi/Q or PM value

MI sector index $(1=5)$

MI distance from release point (m) 0 Use jf data, (T/F) else chi/Q grid/o
Release type (0-3)

Stack release ( $T / F)$

Stack height (m)

Stack flow $(\mathrm{m} 3 / \mathrm{sec})$

Stack radius (m)

Effluent temp. (C)

Building $x$-section $(m 2)$

Building height $(m)$ 


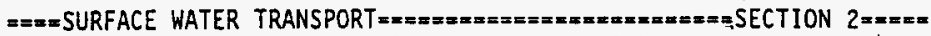
Mixing ratio model: 0-use value, 1-river, 2-lake

Mixing ratio, dimensionless

Average river flow rate for: $\operatorname{MIXFLG=0}(\mathrm{m} 3 / \mathrm{s}), \operatorname{MIXFLG}=1,2(\mathrm{~m} / \mathrm{s})$, Transit time to irrigation withdrawl location (hr)

If mixing ratio model $>0$ :

Rate of effluent discharge to receiving water body $(\mathrm{m} 3 / \mathrm{s})$

Longshore distance from release point to usage location (m)

offshore distance to the water intake (m)

Average water depth in surface water body (m)

Average river width (m), MIXFLG=1 only

Depth of effluent discharge point to surface water $(m)$, lake only

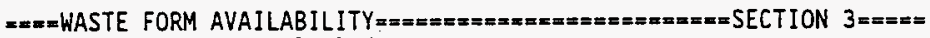
Waste form/package half life, (yr)

Waste thickness, (m)

Depth of soil overburden, $m$

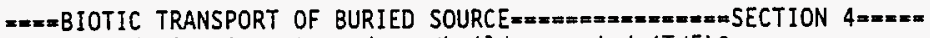
Consider during inventory decay/buildup period $(T / F)$ ?

Consider during intake period (T/F)? |1-Arid non agricultural

Pre-Intake site condition............ 2-Humid non agricultural

3-Agricultura]

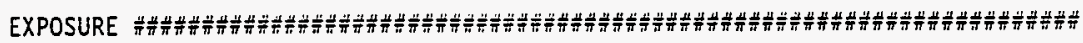

0

0

0

0

0

0

1.0

8766.0

0

0

0

0

ine

0

0

F $==\pi=$ EXTERNAL EXPOSURE $==$ Exposure time:

Piume (hr)

Soil contamination (hr)

Swimming (hr)

Boating (hr)

Shoreline activities (hr) 0

Shorel ine type: (1-river, 2-lake, 3-ocean, 4-tidal basin)

Transit time for release to reach aquatic recreation (hr)

Average fraction of time submersed in acute cloud (hr/person $\mathrm{hr}$ )

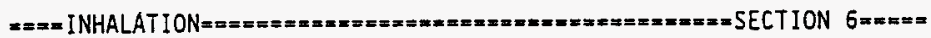
Hours of exposure to contamination per year

$0-$ No resus- I-Use Mass Loading

2-Use Anspaugh model

pension Mass loading factor $(\mathrm{g} / \mathrm{m} 3)$ Top soil available (cm)

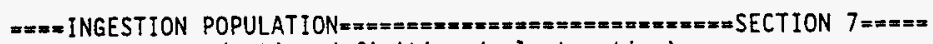
Atmospheric production definition (select option):

0 -Use food-weighted chi $/ Q$, (food-sec/m3), enter value on this

1-Use population-weighted chi/Q

2-Use uniform production

3-Use chi $/ Q$ and production grids (PRODUCTION will be overridden) population ingesting aquatic foods, 0 defaults to total (person) Population ingesting drinking water, 0 defaults to total (person) Consider dose from food exported out of region (default=F) 
Note below: $S^{*}$ or Source: 0-none, I-ground water, 2-surface water 3-Derived concentration entered above $m= \pm$ AQUATIC FOODS / DRINKING WATER INGESTION=m=m=m=mSECTION $8=m=x$ Salt water? (default is fresh)

\begin{tabular}{|c|c|c|c|c|c|c|c|}
\hline $\begin{array}{l}\text { USE } \\
\stackrel{?}{T} / F\end{array}$ & $\begin{array}{l}\text { FOOD } \\
\text { TYPE }\end{array}$ & $\begin{array}{l}\text { TRAN- } \\
\text { SIT } \\
\text { hr }\end{array}$ & $\begin{array}{l}\text { PROD- } \\
\text { UCTION } \\
\mathrm{kg} / \mathrm{yr}\end{array}$ & $\begin{array}{l}\text {-CONSUM } \\
\text { HOLOUP } \\
\mathrm{da}\end{array}$ & $\begin{array}{r}\text { PTION- } \\
\text { RATE } \\
\mathrm{kg} / \mathrm{yr}\end{array}$ & & DRINKING WATER \\
\hline $\begin{array}{l}F \\
F\end{array}$ & $\begin{array}{l}\text { FISH } \\
\text { MOLLUS } \\
\text { CRUSTA } \\
\text { PLANTS }\end{array}$ & $\begin{array}{l}0.00 \\
0.00 \\
0.00 \\
0.00\end{array}$ & $\begin{array}{l}0.0 E \div 00 \\
0.0 E+00 \\
0.0 E+00 \\
0.0 E \div 00\end{array}$ & $\begin{array}{l}0.00 \\
0.00 \\
0.00 \\
0.00\end{array}$ & $\begin{array}{l}0.0 \\
0.0 \\
0.0 \\
0.0\end{array}$ & $\begin{array}{l}0 \\
T \\
0 \\
0\end{array}$ & $\begin{array}{l}\text { Source (see above) } \\
\text { Treatment? T/F } \\
\text { Holdup/transit (da) } \\
\text { Consumption (L/yr) }\end{array}$ \\
\hline
\end{tabular}

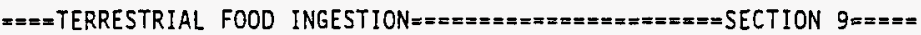

\begin{tabular}{|c|c|c|c|c|c|c|c|c|}
\hline $\begin{array}{l}\text { USE } \\
? \\
\text { T/F }\end{array}$ & $\begin{array}{l}\text { FOOD } \\
\text { TYPE }\end{array}$ & $\begin{array}{l}\text { GROW } \\
\text { TIME } \\
\text { da }\end{array}$ & $\begin{array}{l}\text { - IRRIG } \\
\text { S RATE } \\
\star \text { in/yr }\end{array}$ & $\begin{array}{l}\text { TION-- } \\
\text { TIME } \\
\text { mo/yr }\end{array}$ & $\begin{array}{l}\text { YIELD } \\
\mathrm{kg} / \mathrm{m} 2\end{array}$ & $\begin{array}{l}\text { PROD- } \\
\text { UCTION } \\
\mathrm{kg} / \mathrm{yr}\end{array}$ & $\begin{array}{l}\text {--CONSU } \\
\text { HOLDUP } \\
\mathrm{da}\end{array}$ & $\begin{array}{l}\text { TION-- } \\
\text { RATE } \\
\mathrm{kg} / \mathrm{yr}\end{array}$ \\
\hline $\begin{array}{l}-- \\
F \\
F\end{array}$ & $\begin{array}{l}\text { LEAF V } \\
\text { ROOT V } \\
\text { FRUIT } \\
\text { GRAIN }\end{array}$ & $\begin{array}{l}0.00 \\
0.00 \\
0.00 \\
0.00\end{array}$ & $\begin{array}{l}0.0 \\
0.0 \\
0.0 \\
0.0\end{array}$ & $\begin{array}{l}0.0 \\
0.0 \\
0.0 \\
0.0\end{array}$ & $\begin{array}{l}0.0 \\
0.0 \\
0.0 \\
0.0\end{array}$ & $\begin{array}{l}0.0 \mathrm{E} \div 00 \\
0.0 \mathrm{E} \div 00 \\
0.0 \mathrm{E} \div 00 \\
0.0 \mathrm{E} \div 00\end{array}$ & $\begin{array}{l}0.0 \\
0.0 \\
0.0 \\
0.0\end{array}$ & $\begin{array}{l}0.0 \\
0.0 \\
0.0 \\
0.0\end{array}$ \\
\hline
\end{tabular}

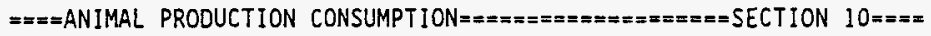

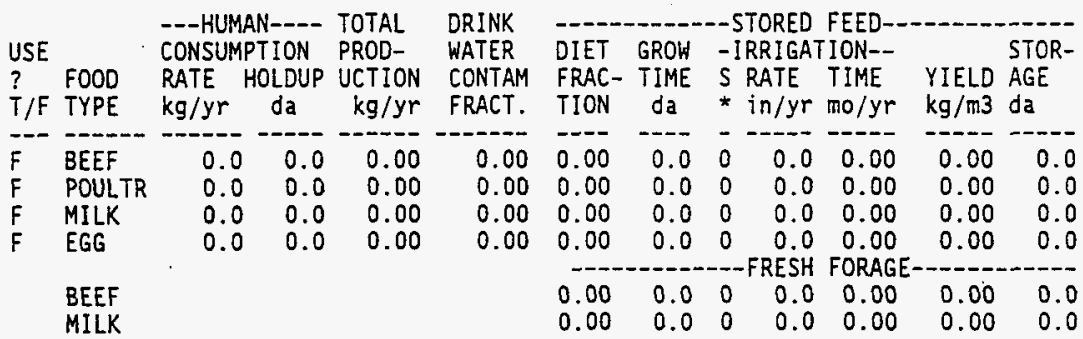


WHC-SD-WM-ISB-003 REV 1

APPENDIX C

SAMPLE ONSITE 100 METERS GXQ INPUT DECK 


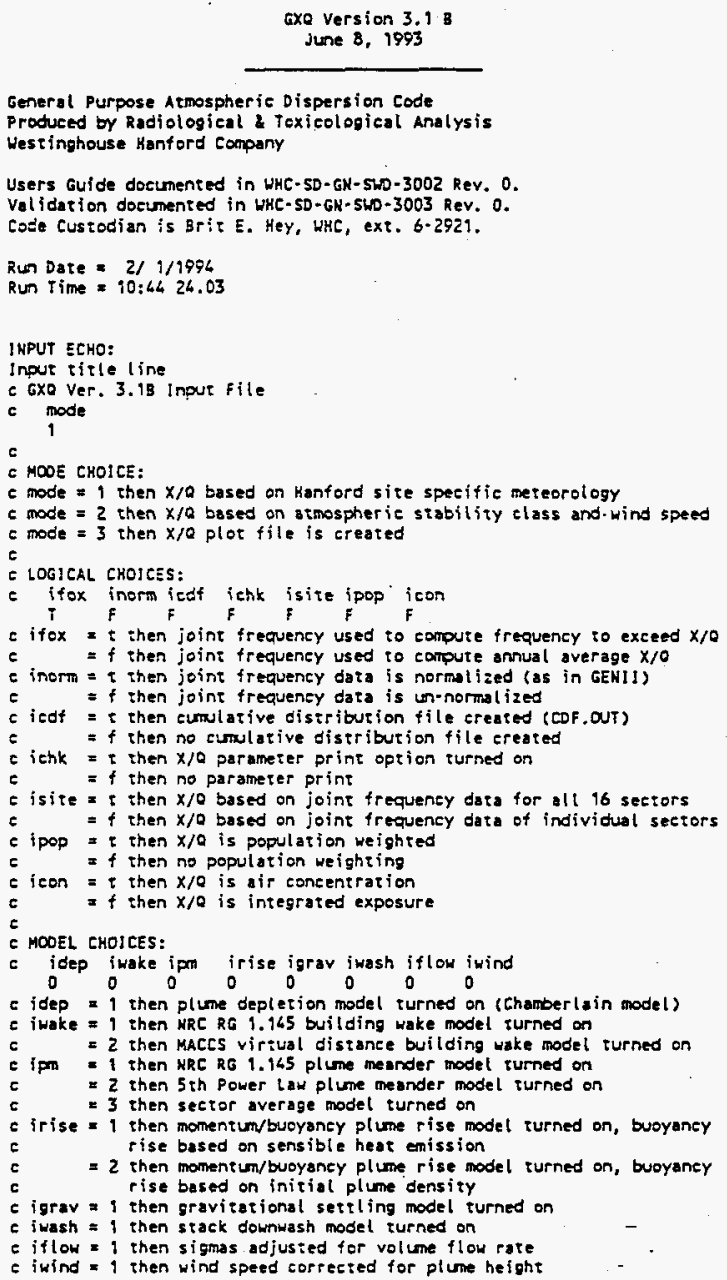




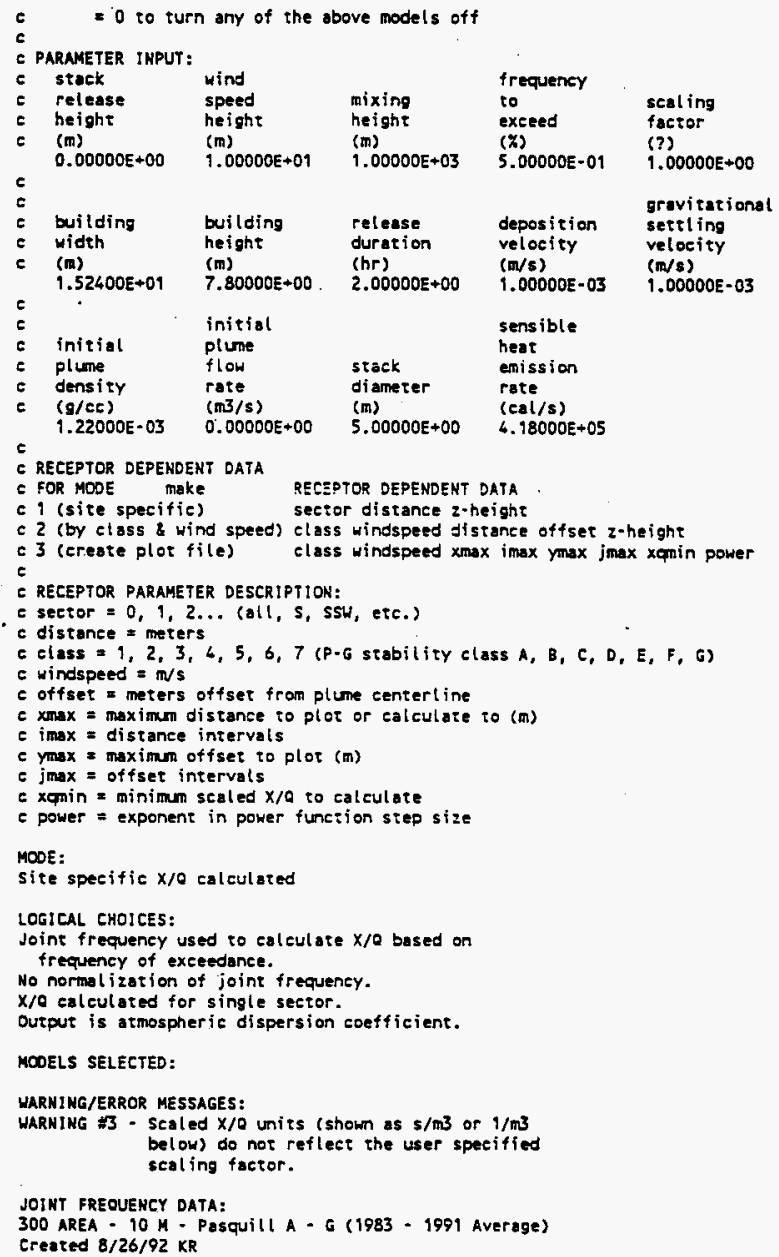

Input ritle line

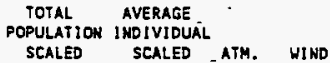


WHC-SD-WM-ISB-003 REV 1

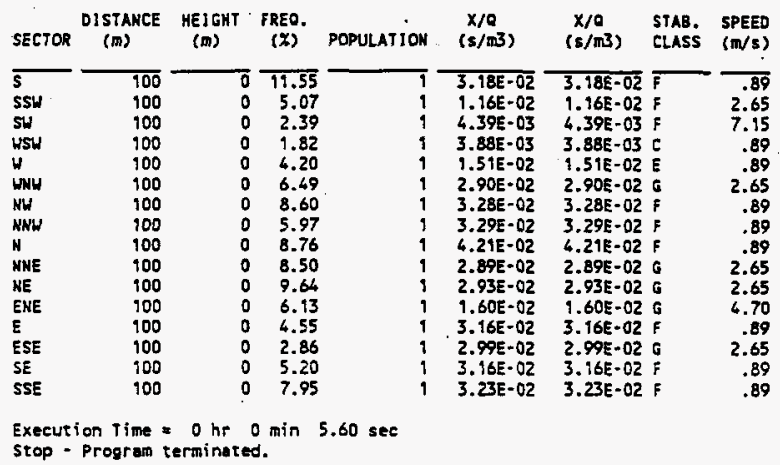


Gxa version 3.1 B

June 8,1993

General Purpose Atmospheric Dispersion Code Produced by Radiological Toxicological Anslys is West inghouse Hanford Company

Users Guide documented in WHC-SD-GN-SWD-3002 Rev. 0. Validation docLmented in WHC-SD-GN-SWD-3003 Rev. 0 . Code Custodian is Brit E. Hey, WHC, ext. 6-2921.

Run Date $=9 / 14 / 1994$

Run Time $=14: 24 \quad 44.26$

INPUT ECHO:

GXo test input file

- exo ver. 3.1 input file

c mode

$$
1
$$

C MOOE CMOICE:

a mode $=1$ then $X / Q$ based on Hanford site specific meteorology

$E$ mode $=2$ then $x / 0$ based on atmospheric stability elass and wind speed

c mode $=3$ then $x / 0$ plot file is created

c Logical CHOICES:

c ifox inorm icdf ichk isite ipop icon

$T \quad F \quad F \quad F \quad F \quad F \quad F$

$c$ ifox $=t$ then joint frequency used to compute frequency to exceed $x / 0$

$5 \quad=f$ then joint frequency used to compute annual aversge $X / 0$

$c$ inorm $=$ : then joint frequency dota is normalized (as in GeNIl)

c $\quad t$ then joint frequency data is un-normalized

icdf $x$ t then cumblative distribution file created (CDF.OUT)

$=$ then no cumblative distribution file created

ichk $z$ t then $X / Q$ parameter prinz option curned on

$=f$ then no parameter print

isite $=2$ then $x / Q$ based on joine irequensy data for all 16 sectors

= $f$ then $x / 0$ based on joint frequeney data of individual sectors

ipop $=$ then $x / 0$ is population weighed

- $f$ then no population weighting

icon $=t$ then $x / Q$ is air concentration

$=f$ then $x / \theta$ is integrated exposure

MOOEL CHOICES:

idep iwake ipm irise igrav iwash iflow iwind
0
0 00

$c$ idep = 1 then plume depletion model turned on (Chamberlain model)

c iwake $=$ i then NRC RG 1.145 building wake model turned on

c 2 then MACCS virtual distance building wake model turned on

c ipm = 1 then NRC RG 1.145 plume meander mode! rurned an

- 2 then 5th Power Law plume meander model turned on

- 3 then sector average model turned on

ifise $=1$ then moment um/buoyaney plume rise model turned on, buoyaney rise based on sensible hear emission

$=2$ then momentum/bubyancy plume pise model turned on, buoyancy rise based on injtial plume density

igrav = $i$ then gravitationsl sertling model turned on

iwash $=1$ then stack downwash model turned on

iflow a I then sigmas adjusted for volume flow rate

iwind $=1$ then wind speed corrected for plume height

- 0 to turn any of the above models off

c 
WHC-SD-WM-ISB-003 REV I

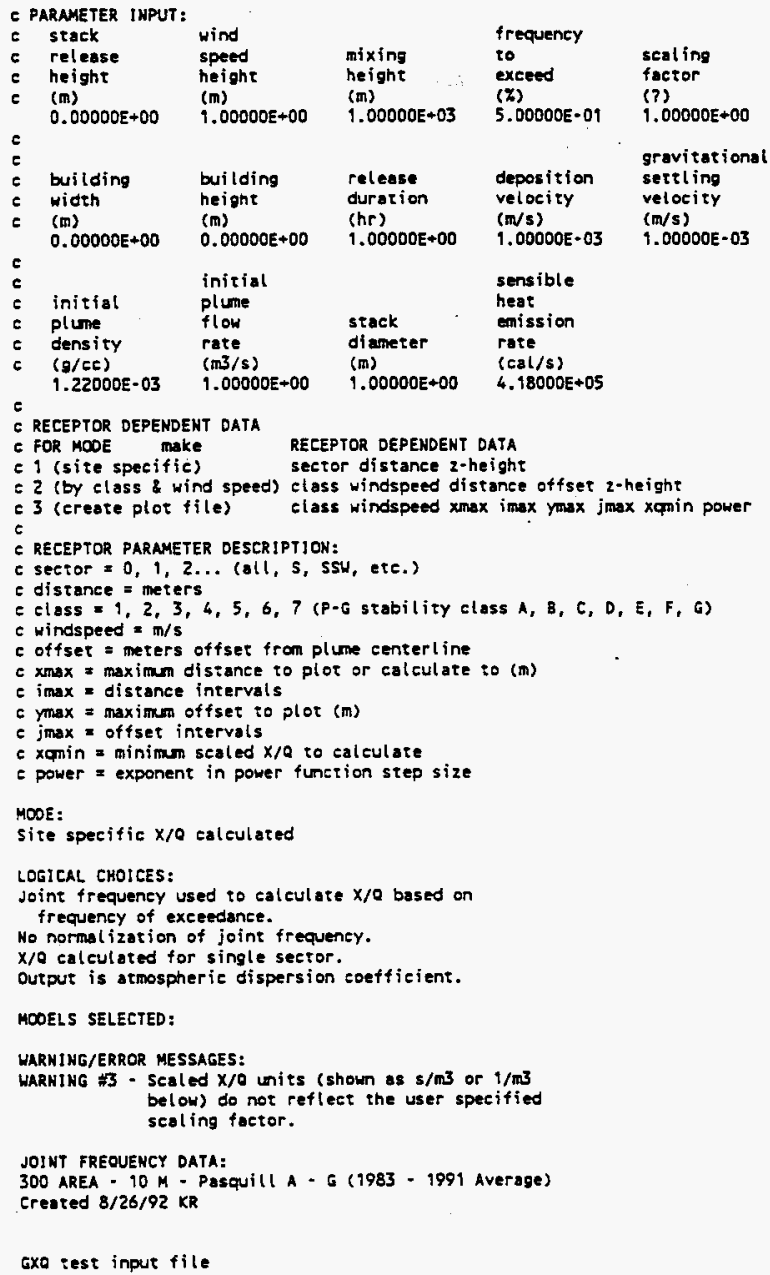

JOINT FREOUENCY DATA:

300 AREA - $10 \mathrm{M}$ - Pasquill A - G (1983 - 1991 Aversge)

Created 8/26/92 KR

Exo rest input file 


\begin{tabular}{|c|c|c|c|c|c|c|c|c|}
\hline SECTOR & $\begin{array}{l}\text { DISTANCE } \\
\text { (m) }\end{array}$ & $\begin{array}{c}\text { RECEPT } \\
\text { HEIGKT } \\
\text { (m) }\end{array}$ & $\begin{array}{l}\text { SECT. } \\
\text { FREO. } \\
(\boldsymbol{X})\end{array}$ & POPULATION & $\begin{array}{l}\text { TOTAL } \\
\text { POPULATION } \\
\text { SCALED } \\
x / 0 \\
(s / m 3)\end{array}$ & $\begin{array}{l}\text { AVERAGE } \\
\text { INDIVIOUAL } \\
\text { SCALED } \\
X / Q \\
\left(5 / \mathrm{mB}^{3}\right)\end{array}$ & $\begin{array}{l}\text { ATH. } \\
\text { STAB. } \\
\text { CLASS }\end{array}$ & $\begin{array}{l}\text { WIND } \\
\text { SPEED } \\
(\mathrm{m} / \mathrm{s})\end{array}$ \\
\hline $\begin{array}{l}S \\
\text { SSW } \\
\text { SH } \\
\text { WSH } \\
H \\
\text { WH } \\
\text { WH } \\
\text { NWW } \\
\text { H } \\
\text { WHE } \\
\text { ME } \\
\text { ENE } \\
\text { E } \\
\text { ESE } \\
\text { SE } \\
\text { SSE }\end{array}$ & $\begin{array}{r}6475 \\
2590 \\
3515 \\
3515 \\
6575 \\
28675 \\
49025 \\
51800 \\
17020 \\
505 \\
505 \\
345 \\
345 \\
345 \\
535 \\
830\end{array}$ & 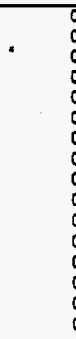 & $\begin{array}{ll}0 & 11.55 \\
0 & 5.07 \\
0 & 2.39 \\
0 & 1.82 \\
0 & 4.20 \\
0 & 6.49 \\
0 & 8.60 \\
0 & 5.97 \\
0 & 8.76 \\
0 & 8.50 \\
0 & 9.64 \\
0 & 6.13 \\
0 & 4.55 \\
0 & 2.86 \\
0 & 5.20 \\
0 & 7.95\end{array}$ & $\begin{array}{l}9 \\
1 \\
1 \\
1 \\
1 \\
1 \\
1 \\
1 \\
1 \\
1 \\
1 \\
1 \\
1 \\
1\end{array}$ & $\begin{array}{l}4.25 E-05 \\
5.36 E-05 \\
1.32 E-05 \\
1.01 E-05 \\
1.88 E-05 \\
6.02 E-06 \\
3.56 E-06 \\
3.33 E-06 \\
1.65 E-05 \\
1.83 E-03 \\
1.85 E-03 \\
1.90 E-03 \\
3.77 E-03 \\
3.58 E-03 \\
1.81 E-03 \\
8.89 E-06\end{array}$ & $\begin{array}{l}4.25 E-05 \\
5.36 E-05 \\
1.32 E-05 \\
1.01 E-05 \\
1.88 E-05 \\
6.02 E-06 \\
3.56 E-06 \\
3.33 E-06 \\
1.65 E-05 \\
1.83 E-03 \\
1.85 E-03 \\
1.90 E-03 \\
3.77 E-03 \\
3.58 E-03 \\
1.81 E-03 \\
8.89 E-04\end{array}$ & $\begin{array}{l} \\
F \\
F \\
E \\
E \\
G \\
F \\
F \\
F \\
6 \\
6 \\
6 \\
G \\
G \\
F \\
F\end{array}$ & $\begin{array}{l}.89 \\
2.65 \\
7.15 \\
4.70 \\
.89 \\
2.65 \\
.89 \\
.89 \\
.89 \\
2.65 \\
2.65 \\
4.70 \\
2.65 \\
2.65 \\
.89 \\
.89\end{array}$ \\
\hline
\end{tabular}




\section{CHECKLIST FOR PEER REVIEW}

Document Reviewed: Loc V. Nguyen, "GENII DOSE CONSEQUENCE CALCULATION FOR

Scope of Review: Entire Document

Yes No NA

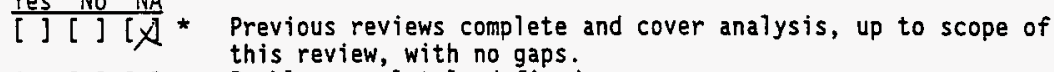
[x] [ ] [ ] Problem completely defined.

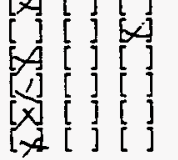

Accident scenarios developed in a clear and logical manner. Necessary assumptions explicitly stated and supported. Computer codes and data files documented.

Data used in calculations explicitly stated in document.

Data checked for consistency with original source information as applicable.

[A [ ] [ ] Mathematical derivations checked including dimensional consistency of results.

[C] [ ] [ ] Models appropriate and used within range of validity or use outside range of established validity justified.

[x] [ ] [ ]

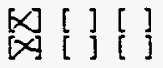

[ ] [ ] [ $x]$ Hand calculations checked for errors. Spreadsheet results should be treated exactly the same as hand calculations. Software input correct and consistent with document reviewed. Software output consistent with input and with results reported in document reviewed.

Limits/criteria/guidelines applied to analysis results are appropriate and referenced. Limits/criteria/guidelines checked against references.

[]$\left[\begin{array}{l}] \\ {[}\end{array}[\not A\right.$

Safety margins consistent with good engineering practices.

Conclusions consistent with analytical results and applicable limits.

[x] [ ] [ ]

[ ] [ ] [x]

Results and conclusions address all points required in the problem statement.

Format consistent with appropriate NRC Regulatory Guide or other standards

[ ] $[\gamma] *$

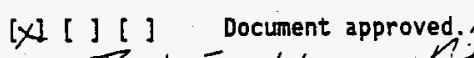

[x] [ ] [ ]

Review calculations,

Document approved.
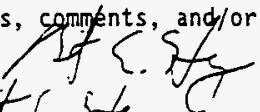

or notes are attached.

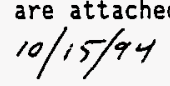

Reviewer (Printed fame and Signature)
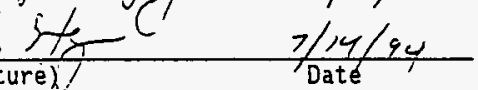

- Any calculations, comments, or notes generated as part of this review should be signed, dated and attached to this checklist. Such material should be labeled and recorded in such a manner as to be intelligible to a technically qualified third party.

[x] [ ] [ ] Analysis entered into analysis database

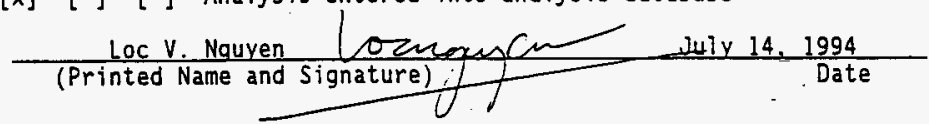




\section{WHC-SD-WM-ISB-003 REV 1 \\ HEDOP REVIEW CHECKLIST \\ for \\ Radiological and Nonradiological Release Calculations}

LOC V. Nguyen, "GENII DOSE CONSEQUENCE CALCULATION FOR THE 340 FACILITY,"

September 14, 1994. Memo, L.V. Nguyen to D. J. Johnson

Submitted by: L. V. Nguyen. Date Submitted: September 1\%, 1994

Scope of Review: Entire Document

YES NO* N/A

[X] [ ] [ ] 1. A detailed technical review and approval of the environmental transport and dose calculation portion of the analysis has been performed and documented.

[ ] [ ] $[x]$ 2. Detailed technical review(s) and approval(s) of scenario and release determinations have been performed and documented.

[X] [ ] [ ] 3. HEDOP-approved code(s) were used.

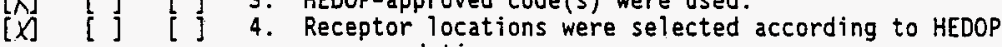
recommendations.

[X] [ ] [ ] 5. All applicable environmental pathways and code options were included and are appropriate for the calculations.

[X] [ ] [ ] 6. Hanford site data were used.

[]$\quad[j[X]$ 7. Model adjustments external to the computer program were justified and performed correctly.

[X] [ ] [ ] 8. The analysis is consistent with HEDOP recommendations.

9. Supporting notes, calculations, comments, comment resolutions, or other information is attached. (Use the "Page $l$ of $X "$ page numbering format and sign and date each added page.)

[X] [ $]$ 10. Approval is granted on behalf of the Hanford Environmentai Dose Overview Panel.

* All "NO" responses must be explained and use of nonstandard methods justified.

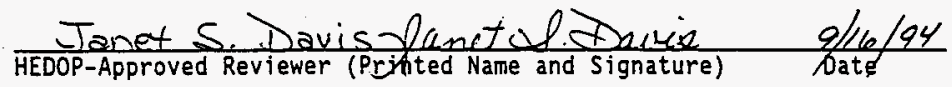

COMMENTS (add additional signed and dated pages if necessary):

3. GENIII (HEDOP-appreved) was uned. GXQ (nor HEDOP-approved) was used to colculati $x / a$ because GENII does not calculate $X / Q s$

in accordance with NRC keg 23 Guide 1.145.

6. Hanford site joint frequency meteorology dato were used in GxQ. 
WHC-SD-WM-ISB-003 REV 1

APPENDIX D

HAZARDOUS MATERIAL RELEASE ESTIMATES

D-1 
WHC-SD-WM-ISB-003 REV 1

This page intentionally without substantive content. 


\section{HAZARDOUS MATERIAL RELEASE ESTIMATES}

A review of the RLWS Disposal Approval Requests prepared by PNL identified the types of hazardous chemicals received at the 340 Facility. A majority of the waste, over $93 \%$, is water. The chemicals appearing most frequently in the waste are:

Nitric Acid

Sodium Hydroxide

Sodium Nitrate

UltimaGold (solvent Di-isopropylnathalene)

Optifluor (solvent alkylbenzene)

Sodium Phosphate

Potassium Persulfate

Sodium Carbonate

Potassium Nitrate

Potassium Hydroxide

Hydrochloric Acid

Sulfuric Acid

Ammonium Hydroxide

oxalic Acid

Dimethyl sulfoxide

PNL uses sodium hydroxide to neutralize nitric acid forming sodium nitrate, the predominate contaminant. This agrees with the 340 Facility Vault Tank sample data shown in Table 2-2.

Using nitrate as the worst-case chemical, the estimated spray release airborne concentrations become:

$$
\text { Spray Release }\left(\mathrm{mg} / \mathrm{m}^{3}\right)=V\left(\mathrm{~m}^{3} / \mathrm{s}\right) \times \times / Q\left(\mathrm{~s} / \mathrm{m}^{3}\right) \times \text { source }\left(\mathrm{mg} / \mathrm{m}^{3}\right)
$$

where

$\begin{array}{lll}V & =5.68 \times 10^{-8} \mathrm{~m}^{3} / \mathrm{s} & \text { Appendix } B \\ X / Q \text { onsite } & =4.21 \times 10^{-2} \mathrm{~s} / \mathrm{m}^{3} & \text { Appendix } C \\ X / Q \text { offsite } & =3.77 \times 10^{-3} \mathrm{~s} / \mathrm{m}^{3} & \text { Appendix } C \\ \text { source } & =3.42 \times 10^{7} \mathrm{mg} / \mathrm{m}^{3} & 3.42 \times 10^{4} \mathrm{mg} / \mathrm{L} \text { in Table 2-2 }\end{array}$

Assuming the source to be $\mathrm{NaNO}_{3}$ the source value becomes:

$$
3.42 \times 10^{7} \times \frac{85 \mathrm{~g} \mathrm{NaNO}_{3}}{65 \mathrm{~g} \mathrm{NO}_{3}}=4.47 \times 10^{7} \mathrm{mg} / \mathrm{m}^{3}
$$


Estimated onsite release concentration:

$0.11 \mathrm{mg} / \mathrm{m}^{3}=5.68 \times 10^{-8} \mathrm{~m}^{3} / \mathrm{s} \times 4.21 \times 10^{-2} \mathrm{~s} / \mathrm{m}^{3} \times 4.47 \times 10^{7} \mathrm{mg} / \mathrm{m}^{3}$

Estimated offsite release concentration:

$$
\begin{aligned}
9.6 \times 10^{-3} \mathrm{mg} / \mathrm{m}^{3}= & 5.68 \times 10^{-8} \mathrm{~m}^{3} / \mathrm{s} \times 3.7710^{-3} \mathrm{~s} / \mathrm{m}^{3} \times \\
& 4.47 \times 10^{7} \mathrm{mg} / \mathrm{m}^{3} .
\end{aligned}
$$

The Hanford Emergency Response Planning Guidelines for chemicals are intended for use in performing site safety classification, hazard evaluations, and emergency preparedness $\mathrm{planning}$ ( $\mathrm{HHC}-\mathrm{CM}-4-46$, Appendix $D$ ). The riskacceptance guidelines for onsite exposure recommends using the ERPG-2 to ERPG-3 values over the frequency range of 1 to $10^{-6}$. For offsite, riskacceptance guidelines recommend using ERPG-1 to ERPG-2 values over the frequency range of 1 to $10^{-6}$. The most restrictive range is ERPG-1 to ERPG-2. ERPG values do not exist for every chemical and WHC-CM-4-46 recommends using threshold limit value - time weighted average (TLV-TWA) values when no ERPG values can be found. Neither ERPG nor TLV-TWA values could be found for $\mathrm{NaNO}_{3}$ using the Hanford information computer listing of ERPG values, the National Institute for Occupational Safety and Health Pocket Guide to Chemical Hazards or the American Conference of Governmental Industrial Hygienists pocket guide for Threshold Limit Values and Biological Exposure Indices. However, using the ERPG limits for a more hazardous chemical provides a greater degree of conservatism and further reduces the risk of adverse effects on the general population. The chemical received at the 340 Facility that presents a potential hazard to personnel, the environment, and the public is sodium hydroxide. The PNL facilities adjust the radioactive liquid waste to a $\mathrm{pH}$ of 10, using sodium hydroxide to reduce corrosion of the stainless steel. The ERPG (Hanford Info) sodium hydroxide values for the comparison are:

$\begin{array}{ccccc}\begin{array}{c}\text { Sodium Hydroxide Onsite } \\ \left(\mathrm{mg} / \mathrm{m}^{3}\right)\end{array} & \begin{array}{c}\text { ERPG-2 } \\ 40\end{array} & \text { to } & \begin{array}{c}\text { ERPG-3 } \\ 100\end{array} & \begin{array}{c}\text { Estimated Value } \\ 0.11\end{array} \\ \begin{array}{c}\text { Sodium Hydroxide } \\ \left(\mathrm{mg} / \mathrm{m}^{3}\right)\end{array} & \begin{array}{c}\text { ERPGite } \\ \mathrm{m}\end{array} & \begin{array}{c}\text { to } \\ \text { ERPG-2 }\end{array} & \begin{array}{c}\text { Estimated Value } \\ 0.0096\end{array}\end{array}$

These values show that comparing the chemical having the highest concentration with the chemical that is a potential hazard for 340 Facility personnel gives values far below the Emergency Response Planning Guidelines. Based on this comparison, releases for the other hazardous chemicals are expected to be well within the risk-acceptance guidelines. 